FELIPE FORNIAS SPERANDIO

AVALIAÇÃO DA REPARAÇÃO TECIDUAL DE EXCISÕES REALIZADAS EM DORSO DE RATOS SUBMETIDAS À TERAPIA FOTO-DINÂMICA COM UTILIZAÇÃO DE CORANTE AZUL DE METILENO 
Felipe Fornias Sperandio

\section{Avaliação da reparação tecidual de excisões realizadas em dorso de ratos submetidas à terapia foto-dinâmica com utilização de corante azul de metileno}

Dissertação apresentada à Faculdade de Odontologia da Universidade de São Paulo, para obter o Título de Mestre, pelo Programa de Pós-graduação em Odontologia.

Área de concentração: Patologia Bucal

Orientadora: Profa. Dra. Suzana Cantanhede Orsini Machado de Sousa 


\section{FOLHA DE APROVAÇÃO}

Sperandio FF. Avaliação da reparação tecidual de excisões realizadas em dorso de ratos submetidas à terapia foto-dinâmica com utilização de corante azul de metileno [Dissertação de Mestrado]. São Paulo: Faculdade de Odontologia da USP; 2009.

São Paulo, 1

\section{Banca examinadora}

1)Prof(a) $\operatorname{Dr}(\mathrm{a})$ :

Titulação:

Julgamento: Assinatura:

2)Prof(a) $\operatorname{Dr}(a)$ :

Titulação:

Julgamento: Assinatura:

3)Prof(a) Dr(a):

Titulação:

Julgamento: Assinatura: 


\section{DEDICATÓRIA}

À minha mãe, Roseli, que nunca mediu esforços para que eu pudesse alcançar meus objetivos na vida e sempre colocou meus estudos em primeiro plano. Sem você, nada seria possível. 


\section{AGRADECIMENTOS}

A Deus.

Ao meu pai Walter, e meu irmão Evandro. À minha avó Elza, minha tia Valquíria e meus tios Walter e Paulo, que sempre me deram o maior apoio e carinho possível.

À Michelle, que sempre esteve ao meu lado, inclusive nos momentos mais difíceis, e a seus pais Sonia e João pelo carinho.

À minha prima Olguinha, e minha tia Maria, por toda a força ao longo de todos estes anos. Obrigado. 


\section{AGRADECIMENTOS}

Profa. Dra. Suzana C.O.M. de Sousa, professora e pesquisadora exemplar, cujo caráter e personalidade são exemplos a seguir. Obrigado por sempre estar lá quando precisei de sua ajuda.

Profa. Dra. Ana Cecília Correa Aranha, com quem convivo há alguns anos e por quem tenho profundo respeito e admiração.

Profa. Dra. Luciana Corrêa, pesquisadora dedicada, a quem sou muito grato por tudo que me ensinou e pelo quanto me auxiliou neste trabalho.

Ao Prof. Dr. Carlos de Paula Eduardo e à Profa. Dra. Patrícia Moreira de Freitas. Obrigado pelo constante incentivo e pelos ensinamentos.

Aos Professores da Disciplina de Patologia Bucal da Faculdade de Odontologia da Universidade de São Paulo: Prof. Dr. Décio dos Santos Pinto Jr., Profa. Dra. Marília Trierveiler Martins, Prof. Dr. Fábio Daumas Nunes, Profa. Dra. Karem Lopez Ortega, Profa. Dra. Marina Helena C. G. Magalhães, Profa. Dra. Andrea Mantesso.

Aos colegas de Pós-Graduação, com quem dividi praticamente os mesmos obstáculos e alegrias. Agradeço a todos vocês: Fernanda Giudice (Valeu, Fê!!!), Fábio Coracin, Arthur, Aluana, Fátima, Alexandra, Aline, Ana Cláudia, Camila, Erika, 
Juliana Schussel, Juliana Noguti, Renata, Roberto, Ronald, Mayra, Magá, Marina, Lourdes Vanesa, Luciana, Paulo Braz, Paulo Santos, Felipe, Brunno, Vanessa, Fernanda Yamamoto, Flávia, Thaís, Valtuir e Yonara.

Às funcionárias da disciplina, pelo carinho e ajuda diária: Elisa, Bia, Zilda, Néia e Nair.

Às amigas do Laboratório Especial de Lasers em Odontologia (LELO): Alyne Simões (sem você este trabalho não seria possível), Daiane T. Meneguzzo, Leila S. Ferreira, Juliana Marotti, Marina Bello Silva e Simone.

Aos meus queridos amigos: Marcelo (Cello), Anely, Mateus, Márcio e Karen.

Às funcionárias do LELO: Lili e Patrícia.

À CAPES pelo apoio financeiro. 
Sperandio FF. Avaliação da reparação tecidual de excisões realizadas em dorso de ratos submetidas à terapia foto-dinâmica com utilização de corante azul de metileno [Dissertação de Mestrado]. São Paulo: Faculdade de Odontologia da USP; 2009.

\section{RESUMO}

A terapia foto-dinâmica consiste na irradiação luminosa de um determinado tecido ou microorganismo previamente exposto à ação de um corante foto-sensibilizador. Ela é eficazmente utilizada em neoplasias e em processos infecciosos. No entanto, poucos estudos avaliam o efeito desta terapia em reparação tecidual. Estes trabalhos mostram resultados que variam entre satisfatórios e não-satisfatórios. Além disso, os estudos que envolvem a terapia com laser em baixa intensidade e a terapia foto-dinâmica em reparação tecidual preocupam-se, na maioria das vezes, com a organização e quantificação dos componentes da matriz extra-celular. Estudar o epitélio, em contrapartida, por meio das proteínas expressas pelos queratinócitos é igualmente importante, sabendo-se que a reparação da ferida depende também da organização e proliferação das células epiteliais. Este trabalho avaliou a reparação tecidual de excisões realizadas em dorso de ratos submetidas à irradiação com laser em baixa intensidade ou terapia foto-dinâmica mediada pelo corante azul de metileno. Para tal, realizou-se a análise morfológica e histomorfológica das feridas em determinados tempos experimentais, além da análise imunoistoquímica das citoqueratinas 10 e 14 e p63. Os resultados mostraram que a reparação tecidual foi favorecida com a irradiação laser em baixa intensidade, o que foi confirmado através das análises morfológica e histo-morfológica que mostraram 
fechamento prévio da ferida para este grupo experimental. Além disso, a expressão de citoqueratina 10 na língua epitelial formada nas feridas pertencentes ao grupo Laser precedeu a expressão da mesma nos outros grupos, o que indicou uma maturação acelerada do epitélio para este grupo. O grupo da terapia foto-dinâmica não apresentou aceleração da reparação tecidual bem como não a prejudicou. Isto sugere que a reparação tecidual frente à irradiação laser é diferente daquela encontrada com a terapia foto-dinâmica. Além disso, não houve atraso da reparação tecidual com a terapia foto-dinâmica, sugerindo que esta terapia foi segura e que devem ser consideradas suas vantagens em situações de infecção.

Palavras-Chave: reparação tecidual, laser em baixa intensidade, terapia fotodinâmica, citoqueratina 10, citoqueratina 14, p63 
Sperandio FF. Wound healing evaluation of excisions performed on the back of rats and submitted to photodynamic therapy mediated by methylene blue dye [Dissertação de Mestrado]. São Paulo: Faculdade de Odontologia da USP; 2009.

\section{ABSTRACT}

The photodynamic therapy involves delivering visible light of the appropriate wavelength into a tissue or microorganism previously exposed to a photo-sensitive dye. Its use is widely spread between neoplastic and infeccious diseases. Nevertheless, its effects upon wound healing has not yet been completely verified and the few studies concerning this subject present whether good or bad results. In addition, studies that involve low intensity laser therapy or photodynamic therapy on wound healing concern mostly on the organization and quantification of the extracellular matrix components. Studying the epithelium, on the other hand, by the keratinocyte expressed proteins is equally important, once the wound healing depends also of the organization and proliferation of the epithelial cells. This study evaluated the wound healing of excisions performed on the back of rats submitted to low intensity laser therapy or photodynamic therapy mediated by methylene blue dye. Morphological and histo-morphological analysis of the wounds in pre-determined periods were performed, as well as immunohistochemistry of citokeratins 10 and 14 and p63. The results showed that the wound healing was enhanced by the low intensity laser therapy, which was confirmed by the morphological and histomorphological analysis. The wound closure was previously seen for the laser group. The citokeratin 10 expression on the epithelial tongue of the wounds that belong to 
the laser group preceded the expression in the other groups, which indicated an accelerated maturation of this epithelium. The photodynamic therapy group did not present accelerated wound healing but did not present any delay as well. This suggests that the wound healing found for the laser group differs from that found for the photodynamic therapy group. Moreover, the lack of delay presented by the photodynamic therapy suggests a safe therapy with advantages regarding disinfection that should be considered in specific situations.

Keywords: wound healing, low intensity laser therapy, photodynamic therapy, citokeratin 10, citokeratin 14, p63 
1 INTRODUÇÃO....................................................................................... 12

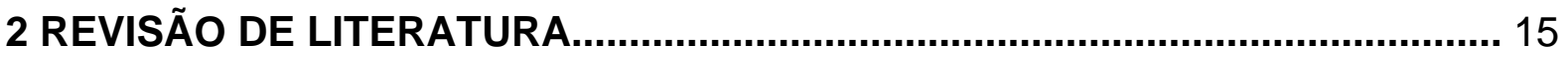

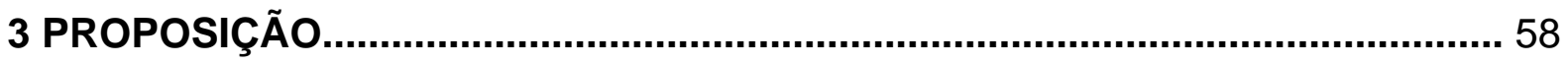

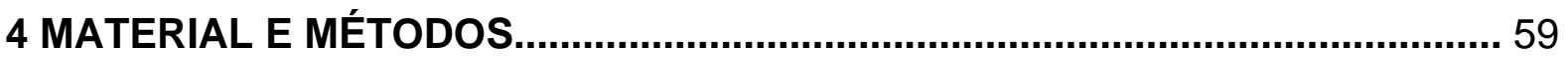

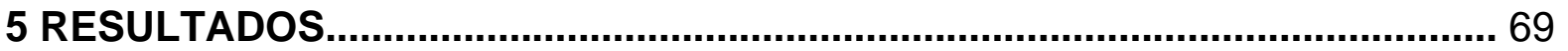

6 DISCUSSÃO................................................................................................ 101

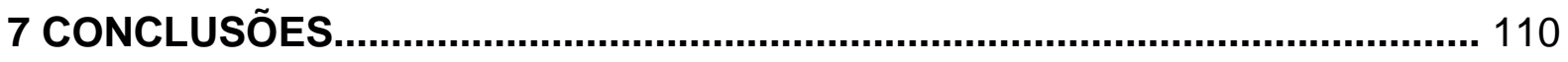

REFERÊNCIAS......................................................................................... 111

ANEXOS.............................................................................................. 136 


\section{INTRODUÇÃO}

A epiderme constitui-se de um epitélio de várias camadas celulares que protege o organismo contra desidratação, trauma mecânico e infecções microbianas. Ela pode se auto-renovar durante toda a vida, sendo esta auto-renovação mediada pela epiderme interfolicular (WATT, 2002) e por células-tronco que residem nos folículos pilosos (OSHIMA et al., 2001).

Quando a barreira física representada pela pele se rompe, como acontece em uma ferida, o organismo torna-se susceptível a infecções por diversos microorganismos. Assim, a reparação tecidual é imprescindível para a vida e se dá por meio da reconstrução parcial da derme, com o recobrimento da área ulcerada pelos queratinócitos.

Quanto mais rápido for o fechamento da ferida, mais rapidamente voltará a haver a continuidade de tecido necessária para oferecer proteção ao organismo. No entanto, a qualidade deste tecido recém-formado também é muito importante e, para avaliá-la, pode-se lançar mão de testes de tração mecânica (ALLENDORF et al., 1997; LYONS et al., 1987).

Uma das alternativas para acelerar a reparação tecidual de feridas cutâneas é a utilização da irradiação laser em baixa intensidade. Com o laser é possível modular processos inflamatórios (VIEGAS et al., 2007), tendo sido recomendado seu uso em pós-operatório devido a sua capacidade de biomodular a reparação tecidual (BRUGNERA JÚNIOR; GENOVESE, 2000; PINHEIRO, 1998; VIEGAS et al., 2005). A terapia com laser em baixa intensidade mostra-se útil no controle da dor, tem ação anti-inflamatória, aumenta a produção de colágeno, a proliferação fibroblástica e a 
micro-vascularização local (CONLAN; RAPLEY; COBB, 1996; DO NASCIMENTO et al., 2004; PESSOA et al., 2004; PINHEIRO et al., 2004).

Além disso, úlceras existentes em pacientes com diabetes tendem a demorar mais tempo do que o normal para serem completamente fechadas, tornando-se um risco para o paciente. Desta maneira, o tratamento com laser em baixa intensidade tem sido útil para a aceleração desta reparação tecidual (AL-WATBAN; ZHANG; ANDRES, 2007; SALTMARCHE, 2008; SCHINDL et al., 1998).

A terapia foto-dinâmica, por sua vez, consiste na irradiação luminosa de um determinado tecido ou microorganismo previamente exposto à ação de um corante foto-sensibilizador. Ela é eficazmente utilizada em neoplasias (ACKROYD et al., 1999; LOU et al., 2004; YANG et al., 2007) e em processos infecciosos (HAMBLIN et al., 2002; JORI et al., 2006; LAMBRECHTS et al., 2005). No entanto, seu uso em reparação tecidual tem sido pouco estudado, e os trabalhos existentes ora mostram resultados promissores (JEFFERIS; CHEVRETTON; BERENBAUM, 1991; SILVA et al., 2004; STERN et al., 1990), ora resultados ruins (KÜBLER et al., 1996; PAREKH et al., 1999).

Os estudos que envolvem a terapia com laser em baixa intensidade e a terapia foto-dinâmica em reparação tecidual preocupam-se na maioria das vezes com a organização e quantificação dos componentes da matriz extra-celular existente em meio à ferida (RIBEIRO et al., 2009; STATIUS et al., 1997). Estudar o epitélio, em contrapartida, através das proteínas expressas pelos queratinócitos é igualmente importante, pois sabemos que a reparação da ferida depende de sua organização e proliferação tanto quanto daquela do tecido subjacente.

As células proliferativas (queratinócitos) existentes na camada basal da epiderme expressam as citoqueratinas 5 e 14 (FUCHS; GREEN, 1980; NELSON; 
SUN, 1983), bem como o fator de transcrição p63 (YANG et al., 1998). E assim que estas células param de proliferar, elas migram da camada basal para a camada espinhosa e passam a expressar as citoqueratinas 1 e 10 (FUCHS; GREEN, 1980). Portanto, é possível identificar as camadas da epiderme, bem como seu estágio de diferenciação pela expressão destas proteínas. 


\section{REVISÃO DE LITERATURA}

\subsection{Reparação tecidual}

A reparação de um tecido cutâneo lesado tem três fases principais: inflamação, formação de tecido de granulação e remodelação do tecido (SINGER; CLARK, 1999). Durante a fase inflamatória, plaquetas, neutrófilos, macrófagos e linfócitos migram para a ferida. A fase proliferativa mostra um aumento de fibroblastos e macrófagos com diminuição dos reagentes de fase aguda. Finalmente, durante a fase de remodelação, os fibroblastos podem ajudar a recriar a matriz extracelular e depositar colágeno (KIRSNER, 2003).

A fase inflamatória tem, como objetivos principais, eliminar microorganismos e limpar a ferida. Assim, a inflamação é requerida para facilitar a reparação tecidual, apesar de a persistência de células inflamatórias além do tempo normal na área da ferida ser um dos fatores mais importantes que causa a demora da reparação (CLARK, 1996).

Após a injúria, a re-epitelização surge geralmente da margem livre da ferida e pode ocorrer também do infundíbulo e do epitélio das glândulas sudoríparas (KUROKAWA; MIZUTANI; KUSUMOTO, 2006). Eisen, Holyoke e Lobitz (1955) mostraram que células sebáceas indiferenciadas se movem para a epiderme interfolicular como parte do reparo tecidual. Lobitz, Holyoke e Montagna (1954), reportaram que, na reparação tecidual, o ducto das glândulas sudoríparas tem papel importante na substituição da epiderme. Os autores ainda demonstraram que o 
ducto das glândulas sudoríparas origina uma língua epitelial (três ou mais células) e que o remanescente deste ducto e de suas porções secretoras não são alteradas morfológica ou histoquimicamente.

A re-epitelização é descrita na literatura por meio de dois mecanismos: o modelo de deslizamento (sliding) e o de rolamento (rolling). Enquanto no modelo de deslizamento os queratinócitos basais são as principais células envolvidas na migração e fechamento da ferida, no modelo de rolamento as principais células envolvidas são os queratinócitos suprabasais da margem da ferida, que "rolam" até o local da injúria (USUl et al., 2005).

O micro-ambiente que circunda a ferida é composto por um tecido de granulação que compreende uma população de macrófagos, fibroblastos e vasos sanguíneos neoformados em meio a uma matriz extra-celular formada por proteínas e polissacarídeos. Esta matriz pode ser modificada por vários fatores inibitórios ou estimulantes, que podem alterar o curso da inflamação e eventualmente levar à fibrogênese (REIS et al., 2008).

Em ratos, a musculatura esquelética subcutânea denominada panniculus carnosus é também injuriada após realização de feridas excisionais, e esta situação especial encontrada nos ratos permite a investigação simultânea da regeneração epitelial e muscular (MUNZ et al., 1999).

Em feridas que reparam por segunda intenção, vários fatores podem contribuir para uma demora da reparação, resultando geralmente em inflamação, edema e cicatrizes (SILVA et al., 2004). As pesquisas nesta área têm seguido três direções básicas: encontrar fatores que acelerem o processo e reduzam a formação de cicatriz, desenvolver substitutos para a pele e identificar fatores que induzam a regeneração da pele (BALASUBRAMANI; KUMAR; BABU, 2001). 
Para modular os efeitos da inflamação podem ser usados medicamentos antiinflamatórios, cuja função consiste em aliviar os sintomas da fase aguda, como edema e dor. Já a irradiação laser, em baixa intensidade, tem a capacidade de estimular componentes celulares de diversos tecidos, incluindo o cicatricial, através de biomodulação. Ela acelera a reparação tecidual por reduzir o edema e infiltrado polimorfonuclear a níveis similares àqueles vistos com a dexametasona (antiinflamatório) (REIS et al., 2008).

A terapia com laser em baixa intensidade também tem efeito sobre a modulação de colágeno (PINHEIRO et al., 2006) e aumenta sua produção, além de deixar a matriz extra-celular melhor organizada (REIS et al., 2008) e ter efeito sobre a expressão de fibras elásticas (PUGLIESE et al., 2003). Isto a torna uma alternativa para a modulação de processos inflamatórios (VIEGAS et al., 2007).

\subsection{Laser em baixa intensidade}

A palavra LASER é um acrônimo para Light Amplification by Stimulated Emission of Radiation, e pode ser traduzida como amplificação da luz por emissão estimulada de radiação. A teoria de emissão estimulada de radiação foi proposta por Einstein em 1917, e o primeiro laser foi construído em 1960 por Mainman.

A luz laser consiste em um tipo peculiar de radiação eletromagnética que apresenta propriedades específicas. O laser é colimado, monocromático e coerente, características estas que o difere das fontes de luz convencionais. 
A terapia com laser em baixa intensidade (LILT - low intensity laser therapy) utiliza a luz nas porções do espectro visível e infravermelho, visando as distintas interações que cada uma é capaz de manter com os tecidos vivos. E além do comprimento de onda utilizado, sabe-se que a interação da luz laser depende da densidade de energia, potência e também das propriedades inerentes ao tecido em questão (DE CASTRO et al., 2005).

A LILT, quando faz uso dos comprimentos de onda adequados, não resulta em efeitos mutagênicos e pode ser utilizada repetidamente, sem riscos (BRUGNERA JÚNIOR; PINHEIRO, 1998). Isto acontece porque seus fótons são de baixa energia, causando somente excitação e calor, e não ionização. Já o raio ultravioleta B e os raios $\mathrm{X}$ estão no espectro abaixo do ultravioleta. Estes possuem fótons de alta energia e podem ionizar átomos, partindo suas ligações químicas e causando mutações (TUNÉR; HODE, 1996).

Além disso, a LILT pode ser utilizada como tratamento coadjuvante em diversas terapias. Porém, é necessário que sejam utilizados os parâmetros corretos para obtenção da resposta biológica adequada. Tais parâmetros incluem o comprimento de onda, a densidade de energia (dose ou fluência), densidade de potência (intensidade ou irradiância), tipo de regime de operação do laser, número de irradiações por sessão e número de sessões.

A densidade de energia pode ser calculada pela quantidade de energia, dada em Joules $(\mathrm{J})$, dividida pela área do spot do laser utilizado ou por centímetro quadrado $\left(\mathrm{J} / \mathrm{cm}^{2}\right)$. Esta é a quantidade de energia por unidade transferida ao tecido, e é o parâmetro mais importante que avalia a possibilidade de estímulo, inibição ou não-manifestação dos efeitos terapêuticos (RIBEIRO; ZEZZEL, 2004). A potência do 
laser é dada em watts (W), e a densidade de potência é a potência de saída de luz por unidade de área, medida em watts por centímetro quadrado $\left(\mathrm{W} / \mathrm{cm}^{2}\right)$.

A ação do laser em baixa intensidade se dá pela absorção de luz por moléculas do tecido alvo chamadas de cromóforos. E diferentemente dos lasers de alta potência, a LILT não provoca aumento significante de temperatura nos tecidos, uma vez que sua potência varia entre 5 e $500 \mathrm{~mW}$, enquanto a potência dos lasers cirúrgicos podem chegar a 300 W (SOBANKO; ALSTER, 2008).

Geralmente, os comprimentos de onda utilizados para realização da LILT estão compreendidos entre 600 e 900nm, que é exatamente o espectro de luz capaz de causar algum efeito sobre os tecidos vivos (WILDEN; KERTHEIN, 1998). Os lasers mais comumente utilizados e seus respectivos comprimentos de onda são os de: Hélio-neônio (HeNe; 632.8nm), rubi (694nm), argônio (488 e 514nm), criptônio (krypton) (521, 530, 568, 647nm), arseneto de gálio (GaAs; 904nm) e arseneto de gálio-alumínio (GaAIAs; 820, 830nm).

Karu (1989), estudando os efeitos da luz visível (vermelha) na estimulação de sistemas biológicos, concluiu que esta promove mudanças fotoquímicas nos receptores das mitocôndrias, alterando o metabolismo. Há envio dos sinais para outras áreas da célula e geração da foto-resposta (biomodulação). A absorção da radiação emitida na região do espectro infravermelho, no entanto, resulta em rotações e vibrações moleculares. São propriedades que a diferem da radiação visível.

Algumas condições como baixa concentração de oxigênio, pH ácido e falta de nutrientes podem atrasar a proliferação celular em feridas (KARU, 1989). Assim, a resposta de um tecido frente à luz laser pode ser estimulação ou inibição. Um 
modelo satisfatório para se estudar os efeitos da LILT em tecidos vivos é o uso in vitro de diferentes linhagens de células em cultura (DE CASTRO et al., 2005).

Apesar dos mecanismos da LILT não estarem totalmente elucidados (BASFORD, 1995), há vários estudos que comprovam seu benefício clínico em relação à diminuição de dor, aceleração da reparação tecidual e modulação de funções celulares. Sabe-se que a LILT altera os processos intra-celulares tanto em animais como em bactérias de uma maneira não-térmica e ao mesmo tempo dependente do comprimento de onda utilizado (ENWEMEKA, 1992; FORK, 1971; KARU, 1987; KARU et al., 1996; KARU; ANDREICHUK; RYABYKH, 1993; KARU; PYATIBRAT; RYABYKH, 1997; LUBART et al., 1997). Vários estudos, tanto em cultura de células como em animais e humanos têm sido feitos de forma a avaliar seus possíveis efeitos (BASFORD, 1995; CONLAN; RAPLEY; COBB, 1996; WALSH, 1997).

Silveira, Streck e Pinho (2007) realizaram um estudo de maneira a avaliar as atividades dos complexos II e IV da cadeia respiratória mitocondrial e succinato dehidrogenase após irradiação com laser em baixa intensidade em feridas no dorso de ratos. O laser utilizado neste estudo foi de arseneto de gálio (AsGa), emitindo luz com comprimento de onda de $904 \mathrm{~nm}$. Os resultados mostraram melhora na reparação tecidual quando o laser foi utilizado, sendo que o tamanho das feridas irradiadas com laser foi significantemente menor aos três e dez dias após a ulceração. Os resultados também mostraram, pela primeira vez na literatura, aumento significativo na atividade dos complexos II nas feridas irradiadas com a luz laser, porém não na atividade da succinato dehidrogenase. Além disso, o trabalho mostrou resultados coerentes com a literatura prévia, onde a citocromo c oxidase (complexo IV da cadeia respiratória mitocondrial) foi ativada pela LILT. 
É sugerido pelos trabalhos publicados, que a citocromo c oxidase absorva luz no espectro infravermelho próximo (KARU; PYATIBRAT; KALENDO, 1995; WONGRILEY et al., 2001; WONG-RILEY et al., 2005). Porém, a irradiação laser entre 660 e $680 \mathrm{~nm}$ (luz vermelha) aumentou a transferência de elétrons em citocromo oxidase purificada (PASTORE; GRECO; PASSARELLA, 2000), aumentou a respiração mitocondrial e síntese de adenosina trifosfato (ATP) em mitocôndrias isoladas (PASSARELLA et al., 1984) e aumentou (up-regulation) a atividade da citocromo c oxidase em células nervosas em cultura (WONG-RILEY et al., 2001).

Karu, Pyatibrat e Kalendo (1995) mostraram também que a irradiação com laser de hélio neônio (He-Ne), 633nm, aumentou a síntese de ATP nas células. Isto mostra compatibilidade com o estudo de Silveira, Streck e Pinho (2007), em que a atividade dos complexos II e IV apresentava-se aumentada.

Outros estudos mostram que a irradiação com laser emitindo luz com comprimentos de onda de 415,602,633, 650 e 725nm é capaz de aumentar a síntese de ATP (GORDON; SURREY, 1960; KATO; SHINZAWA; YOSHIKAWA, 1981; PASSARELLA et al., 1984; VEKSHIN; MIRONOV, 1982). Já a luz laser com comprimentos de onda de 477, 511 e 554nm não parece ter influência sobre o mesmo processo (KATO; SHINZAWA; YOSHIKAWA, 1981).

Há resultados distintos em relação à proliferação celular quando diferentes protocolos de LILT são utilizados (BASFORD, 1995; KARU, 1990; LOPES; RIGAU; ZANGARO, 2001; ORIGINALI, 1981). Além destes protocolos, o estado fisiológico da célula também é capaz de interferir nos efeitos proliferativos da luz laser (PINHEIRO et al., 2002).

Liu et al. (2006) avaliaram o possível mecanismo pelo qual a irradiação laser inibiu a proliferação de hepatócitos humanos (células HepG2 e J-5). Estudos prévios 
realizados pelo autor (LIU et al., 2004) indicam um efeito inibitório na proliferação destas mesmas linhagens celulares quando foram irradiadas com um laser de arseneto de gálio e alumínio (GaAlAs), operando num comprimento de onda de $808 \mathrm{~nm}$ (modo contínuo) e densidade de energia de $5.85 \mathrm{~J} / \mathrm{cm}^{2}$ e $11.7 \mathrm{~J} / \mathrm{cm}^{2}$, respectivamente para as células HepG2 e J-5.

Neste estudo, a diminuição do número de células HepG2 e J-5 poderia estar relacionada com a diminuição da síntese de ácido desoxirribonucléico (DNA), já que observou-se menor expressão (downregulation) de histonas nas células irradiadas. Além disso, houve redução de síntese de sinemina e alteração do citoesqueleto das células HepG2 e J-5. Portanto, a irradiação laser poderia primariamente reduzir a expressão de sinemina e, quando esta estivesse deficiente, a organização dos microtúbulos e filamentos intermediários seria rompida, levando à provável perda da integridade e morfologia celular. Os autores concluíram que o mecanismo envolvido no efeito inibitório observado pode se dar por meio de: 1- redução da síntese de histonas, desorganizando a replicação do DNA e, posteriormente reduzindo a proliferação destas células; ou 2- redução da síntese de sinemina, o que leva à destruição da organização do citoesqueleto e causa dano às células.

A maioria dos estudos mostra que a irradiação laser pode aumentar a proliferação de células humanas (KREISLER et al., 2003; LOEVSCHALL; ARENHOLT-BINDSLEV, 1994). No entanto, há relatos indicando o efeito inibitório desta irradiação sobre a proliferação celular, como o estudo de Liu et al. (2006). Shu et al. (2002) mostraram que a irradiação com laser de He-Ne, com uma densidade de energia de $180 \mathrm{~J} / \mathrm{cm}^{2}$, diminuiu o número de fibroblastos quando comparado ao controle. 


\subsection{Laser em baixa intensidade na reparação tecidual}

Mester foi um dos pioneiros na utilização do laser de baixa potência com finalidade terapêutica e, junto com seus colaboradores, notou melhora na reparação tecidual com aplicação de laser de rubi operando em baixas densidades de energia (1 J/cm²) (MESTER et al., 1975; MESTER et al., 1971; MESTER; MESTER; MESTER, 1985).

Devido ao papel crucial desempenhado pelos fibroblastos na reparação tecidual, muitos estudos publicados examinam os efeitos da LILT no crescimento celular, locomoção e produção de colágeno destas células (POSTEN et al., 2005). Abergel et al. (1987) mostraram não haver diferenças na proliferação celular de fibroblastos expostos à irradiação laser. Os autores ainda demonstraram haver declínio da proliferação de fibroblastos, se comparado ao controle, quando estes foram irradiados com o laser de GaAs. Este estudo foi realizado em cultura de células de fibroblastos e os lasers utilizados foram o de He-Ne (632 nm) com densidade de energia variando entre 0.053 a $1.589 \mathrm{~J} / \mathrm{cm}^{2}$ e o de GaAs (904nm) com densidade de energia variando entre $1.94 \times 10^{-7}$ e $5.84 \times 10^{-6} \mathrm{~J} / \mathrm{cm}^{2}$. Os autores notaram, entretanto, um aumento na produção de pro-colágeno induzida por ambos os lasers (ABERGEL et al., 1987).

Mudanças no arranjo citomorfológico de fibroblastos gengivais puderam ser notadas após irradiação destes com o laser de neodímio (Nd:YAG) (CHEN et al., 2002). Noble et al. (1992) notaram diminuição da capacidade de locomoção dos fibroblastos em um ambiente tridimensional de colágeno quando as células foram expostas à irradiação com laser de He-Ne. Os autores especularam ser esta 
diminuição de locomoção devida ao concomitante aumento da produção de colágeno dos fibroblastos (NOBLE et al., 1992).

Pereira et al. (2002) mostraram haver aumento da proliferação de fibroblastos humanos expostos à irradiação com laser de GaAs (904nm) sem implicar em mudanças na síntese de pró-colágeno. Já Medrado et al. (2003), observaram aumento do número de miofibroblastos e deposição de colágeno em ratos, após irradiação com laser de GaAsAl (670nm).

Foi também reportado aumento no número de fibroblastos gengivais após exposição destes aos lasers de diodo $(670,692,780,786 \mathrm{~nm})$ (ALMEIDA-LOPES et al., 2001).

Além dos numerosos estudos realizados acerca de LILT sobre o comportamento de fibroblastos, existem trabalhos que analisam o comportamento de outros fatores que dizem respeito à reparacão tecidual frente a irradiação laser.

Haas et al. (1990) avaliaram o efeito da irradiação com laser de He-Ne em queratinócitos humanos in vitro e notaram aumento na motilidade destas células, sem haver diferenças na proliferação ou diferenciação das mesmas (HAAS et al., 1990; ROOD et al., 1992). Grossman et al. (1998) notaram estimulação da proliferação de queratinócitos após estes serem expostos a um laser de diodo com emissão contínua (780nm) e densidade de energia de até $3.6 \mathrm{~J} / \mathrm{cm}^{2}$.

A maioria dos estudos realizados descreve aumento na deposição de colágeno e proliferação de fibroblastos, células endoteliais e queratinócitos quando expostos à luz laser. Além disso, os estudos realizados com cultura de células fornecem um modelo teórico para os efeitos da LILT na reparação tecidual. No entanto, há estudos publicados que mostram resultados conflitantes. Esta divergência de resultados pode ser atribuída a uma disparidade da metodologia 
utilizada, incluindo o uso de diferentes aparelhos laser, variação dos parâmetros e diferenças nas técnicas de cultura de células. Desta forma, examinar os efeitos da LILT sobre a reparação tecidual em diferentes modelos animais, como ratos, providenciam uma simulação mais realística destes efeitos sobre a pele humana (POSTEN et al., 2005).

De maneira geral, estes trabalhos mostram uma aceleração da reparação tecidual das feridas irradiadas com laser se comparadas àquelas que não sofreram irradiação (KANA et al., 1981; BISHT et al., 1994). Há estudos que, ao contrário, relatam não haver diferenças significativas entre os grupos analisados (ANNEROTH et al., 1988).

Kana et al. (1981) utilizaram lasers de He-Ne (632.8 nm) e de Argônio (514.5 $\mathrm{nm}$ ), com doses variando entre 4 e $20 \mathrm{~J} / \mathrm{cm}^{2}$ em feridas realizadas na pele de ratos por meio de punch cirúrgico. Os autores encontraram uma aceleração da reparação tecidual nas feridas tratadas com a dose mais baixa de $4 \mathrm{~J} / \mathrm{cm}^{2}$, e demora na reparação naquelas tratadas com dose de $20 \mathrm{~J} / \mathrm{cm}^{2}$. Os autores também observaram que ambos os lasers aumentaram a expressão de colágeno na área da reparação.

Em estudo semelhante, Bisht et al. (1994) investigaram o efeito da LILT com laser de He-Ne a uma dose de $4 \mathrm{~J} / \mathrm{cm}^{2}$ em feridas realizadas na pele de ratos. Os autores observaram aumento do tecido de granulação e da expressão de colágeno nas feridas irradiadas com o laser.

Apesar destes estudos, Anneroth et al. (1988) usaram um laser de GaAs (904nm) em um modelo experimental semelhante ao usado por Kana et al. (1981), e não encontraram qualquer diferença na velocidade de reparação ou na formação do tecido de granulação nas feridas irradiadas pelo laser. 
Viegas et al. (2007) avaliaram a ação da LILT na modulação da resposta inflamatória durante a reparação tecidual de excisões realizadas no dorso de ratos e compararam os resultados com excisões tratadas com um medicamento antiinflamatório, o meloxicam. Seus resultados permitiram-lhes concluir, por meio da análise dos níveis de RNA mensageiro (mRNA) de interleucina 1- $\beta$, que o meloxicam apresentou efeito anti-inflamatório, enquanto que a irradiação laser, estivesse ela operando no comprimento de onda vermelho ou infra-vermelho, não apresentou este efeito. Os autores também concluíram que apesar da irradiação laser não ter este efeito anti-inflamatório apresentado pelo meloxicam, as feridas irradiadas com luz laser (vermelha e infra-vermelha) apresentaram melhora da qualidade de reparação tecidual, comprovada pela análise histológica.

Reis et al. (2008) investigaram o processo de reparação tecidual decorrente de feridas realizadas em pele de ratos e tratadas com dexametasona (droga antiinflamatória) e/ou com LILT. A LILT consistiu de um laser de GaAIAs (670nm) com uma densidade de energia de $4 \mathrm{~J} / \mathrm{cm}^{2}$. Os autores puderam concluir que a LILT, por si só, acelera o processo de reparo tecidual, reduzindo edema e infiltrado inflamatório polimorfonuclear a níveis similares àqueles atingidos pela dexametasona, porém a LILT também aumenta a produção de colágeno e apresenta uma matriz extra-celular mais bem organizada aos cinco dias de pós-operatório.

Pessoa et al. (2004) realizaram estudo semelhante com um laser de GaAlAs $(904 \mathrm{~nm})$ e densidade de energia de $33 \mathrm{~J} / \mathrm{cm}^{2}$. Os autores perceberam que os animais tratados com um corticóide (dexametasona) tiveram uma demora na reparação tecidual, enquanto que o protocolo de LILT utilizado foi capaz de promover diminuição do infiltrado inflamatório, maior diferenciação epitelial na região das feridas com maior deposição de colágeno e aceleração da reparação tecidual. 
Assim, o laser pôde agir como um coadjuvante no processo reparacional, contrabalanceando os efeitos indesejáveis causados pelo corticóide.

Medrado et al. (2003) demonstraram que na fase inicial da reparação tecidual, especialmente no terceiro dia após a injúria, os animais tratados com laser de GaAIAs com uma densidade de energia de $4 \mathrm{~J} / \mathrm{cm}^{2}$ apresentavam um maior número de fibroblastos com retículo endoplasmático rugoso e complexo de Golgi bem desenvolvidos e numerosas mitocôndrias se comparados aos animais do grupo controle. No estudo realizado por Reis et al. (2008), estes dados foram confirmados, sendo que no terceiro e quinto dias após a injúria causada, foi revelado que o número de fibroblastos era maior nos grupos que tomaram contato com a luz laser em baixa intensidade. Além disso, as organelas destes fibroblastos (complexo de Golgi e retículo endoplasmático rugoso) eram bem desenvolvidas e estas células estavam distribuídas em meio a fibras colágenas paralelas e organizadas, implicando num efeito biomodulador da LILT na síntese de proteínas.

Ribeiro et al. (2009) estudaram o efeito da LILT (660nm) com uma densidade de energia de $20 \mathrm{~J} / \mathrm{cm}^{2}$ sobre miofibroblastos e linfócitos T e B durante a reparação tecidual de feridas realizadas no dorso de ratos. Os autores puderam concluir que o protocolo de LILT utilizado no estudo promoveu um significante aumento do número de miofibroblastos aos oito dias de pós-operatório. Isto sugeriu que a irradiação laser estimulou a diferenciação de fibroblastos em miofibroblastos nos primeiros tempos de reparação tecidual e, provavelmente acelerou a contração da ferida. Os autores ainda concluíram que a LILT pareceu modular a resposta inflamatória, diminuindo a proliferação de linfócitos durante o processo reparacional, melhorando a reparação tecidual das feridas. 
Como mencionado anteriormente, o uso de diferentes aparelhos laser, bem como potência e densidade de energia, pode levar a resultados distintos. Do Nascimento et al. (2004) realizaram um estudo com o objetivo de avaliar o efeito de diferentes comprimentos de onda e intensidades de LILT sobre o processo de reparação de feridas cutâneas em dorso de ratos. Os autores utilizaram dois comprimentos de onda: 670 e $685 \mathrm{~nm}$ com uma mesma densidade de energia, porém variando a potência: 2, 15 e $25 \mathrm{~mW}$. Os resultados do estudo permitiram concluir que há uma relação inversamente proporcional entre comprimento de onda e potência, sendo o tratamento mais efetivo aquele que combina um comprimento de onda baixo com alta potência ou comprimento de onda alto com baixa potência.

Ainda no estudo de Do Nascimento et al. (2004), foi observado que a fase inflamatória era menos intensa e mais avançada nos animais que sofreram LILT se comparados ao controle. A inflamação ainda foi menos intensa quando o comprimento de $670 \mathrm{~nm}$ foi usado ou quando a potência de $2 \mathrm{~mW}$ foi usada, o que é explicado pela instalação mais breve da resposta inflamatória quando comprimentos de onda mais curtos são utilizados (BASFORD, 1995; PINHEIRO, 1998; RIGAU, 1996).

Gál et al. (2006) estudaram o efeito de um laser de AIGalnP (670nm; 30J/cm²) no processo de reparação de feridas causadas no dorso de ratos. Os autores concluíram que a LILT acelerou a regeneração da epiderme, a reparação da derme e da musculatura estriada injuriada. Os autores ainda advertem os leitores de que apesar da LILT ser benéfica sobre as feridas cutâneas, os mesmos efeitos podem não ser encontrados em feridas crônicas ou em outros tecidos. 
Os efeitos da LILT sobre a reparação tecidual também podem ser estudados por meio da tensão mecânica das feridas (ALLENDORF et al., 1997; LYONS et al., 1987).

As feridas causadas para estudo podem ter diferentes etiologias como, por exemplo, feridas causadas por queimadura (SCHLAGER et al., 2000a, b). Além disso, a LILT tem sido estudada como alternativa para o tratamento de animais cuja reparação tecidual é deficiente devido a uma condição patológica, como em ratos diabéticos (STADLER et al., 2001). Stadler et al. (2001) mostraram haver aumento da força de tensão de feridas cutâneas realizadas em ratos diabéticos e expostas à LILT com laser de diodo (830 nm) com densidade de energia de $5 \mathrm{~J} / \mathrm{cm}^{2}$.

Al-Watban, Zhang e Andres (2007) compararam os efeitos de diferentes comprimentos de onda e doses de LILT na reparação tecidual de ratos diabéticos. $O$ estudo utilizou-se dos comprimentos de onda de 532, 633, 810 e 980nm com lasers de diodo e doses de 5, 10, 20 e $30 \mathrm{~J} / \mathrm{cm}^{2}$. A irradiação laser pôde acelerar a reparação tecidual dos ratos diabéticos, sendo que o comprimento de onda de $633 \mathrm{~nm}$ e a dose de $10 \mathrm{~J} / \mathrm{cm}^{2}$ consistiram no tratamento mais eficiente encontrado pelos autores.

A razão da efetiva aceleração da reparação tecidual em ratos diabéticos tratados com LILT é, provavelmente, a absorção da luz pelo tecido, resultando na proliferação de fibroblastos e conseqüente aumento da produção de colágeno e formação do tecido de granulação (AL-WATBAN; ZHANG; ANDRES, 2007), uma vez que a deficiência da reparação de feridas diabéticas provavelmente se dá por metabolismo alterado dos fibroblastos e formação anormal do tecido de granulação (SPANHEIMER, 1988). 
Quando expostos à luz laser (632.8nm), os fibroblastos de pele humana em cultura, simulando um modelo de ferida em diabético, tiveram estimulada sua migração com uma dose de $5 \mathrm{~J} / \mathrm{cm}^{2}$. Já com uma dose de $16 \mathrm{~J} / \mathrm{cm}^{2}$, as mesmas células sofreram inibição de proliferação e danos genéticos (HOURELD; ABRAHAMSE, 2007).

Estudos realizados em seres humanos também relacionam a reparação de feridas tratadas com LILT com aquelas não tratadas. Schindl, Schindl e Schindl (1997) verificaram melhora na reparação tecidual de uma úlcera de radiação persistente após ter sido ela irradiada com laser de He-Ne com dose de $31.5 \mathrm{~J} / \mathrm{cm}^{2}$. Outro estudo mostra a melhora de um paciente acometido por úlcera diabética no pé após ser tratado com laser de diodo $(670 \mathrm{~nm})$ somado à terapia antibiótica (SCHINDL et al., 1998).

Saltmarche (2008) estudou o efeito da LILT sobre úlceras crônicas e agudas em dezesseis pacientes. Os pacientes incluídos no estudo apresentavam úlcera por diabetes, por insuficiência venosa ou por pressão. Ao final das nove semanas, a maioria das feridas tratadas com laser (61.8\%) apresentou melhora (mais do que $50 \%$ do fechamento da ferida). Dentre estas, nove feridas $(42.8 \%)$ apresentaram $100 \%$ de fechamento.

Outros pesquisadores não encontraram diferenças significativas quando compararam o grupo laser com o grupo placebo. Em geral, estes trabalhos foram realizados com grupos maiores de pacientes.

Sobanko e Alster (2008) realizaram uma revisão sobre os trabalhos que se utilizaram da LILT para tratamento de úlceras crônicas em humanos. Dentre a maioria dos trabalhos analisados pelos autores, não foram demonstradas diferenças significativas entre os grupos tratados ou não com a luz laser. 
Lundeberg e Malm (1991) compararam o efeito do laser de He-Ne com uma dose de $4 \mathrm{~J} / \mathrm{cm}^{2}$ com o grupo placebo no tratamento de 46 úlceras venosas e não encontraram diferenças significativas quando examinando a porcentagem de área reparada após 12 semanas. Lagan et al. (2001) também não encontraram diferenças significativas quando examinando a taxa de reparação de feridas pós-cirúrgicas tratadas ou não com laser de GaAIAs (830nm) com dose de $9 \mathrm{~J} / \mathrm{cm}^{2}$.

Recentemente, a NASA (National Aeronautics and Space Administration), usou um diodo emissor de luz (LED - light-emitting diode) emitindo luz com comprimento de onda de 670nm e estudou seus efeitos na reparação tecidual (KAUFMAN, 2006; WHELAN et al., 2001). Esta luz não apresenta as mesmas propriedades da luz laser, pois não é uma luz colimada e coerente. No entanto, apresenta algumas vantagens.

O LED é uma tecnologia mais barata do que o laser e pode atuar sobre áreas mais amplas do que o mesmo, tornando-se bastante útil para algumas ocasiões, como o tratamento de mucosite em humanos (WHELAN et al., 2001).

Outro estudo que avaliou o efeito de um LED sobre a reparação tecidual foi o de Erdle et al. (2008). Neste estudo foi demonstrado que uma luz vermelha com comprimento de onda de 670nm emitida por um LED, pode acelerar a reparação tecidual em incisões realizadas em ratos e também, apesar de não tão efetivamente, em feridas causadas por queimadura. Os autores ainda concluem que esta pode ser uma tecnologia bastante útil e que estudos em humanos, além daqueles existentes na área de mucosite, devem ser levados adiante (ERDLE, 2008). 


\subsection{Terapia foto-dinâmica}

A terapia foto-dinâmica ou PDT (photodynamic therapy) consiste na irradiação luminosa de um determinado tecido ou microorganismo previamente exposto à ação de um corante. Este corante deve ser sensível ao comprimento de onda da luz utilizada.

Existem diversos tipos de corantes foto-sensibilizantes e o mais utilizado mundialmente é o ácido 5 amino-levulínico (ALA). A terapia foto-dinâmica mediada por ALA mostrou ser eficiente na inativação do vírus da herpes simples (HSV) in vivo (SMETANA et al., 1997).

Outro corante, muito utilizado no Brasil tanto em pesquisas como na área clínica, é o azul de metileno. Este corante já vem sido utilizado na prática médica por vários anos e é reconhecido por ter propriedades de foto-inativação viral desde 1928 (SCHULTZ; KRUEGER, 1928). Ele também é conhecido por ser mais seguro ou menos tóxico do que outros corantes (CHAN; LAI, 2003).

Os corantes podem ser injetados, ingeridos ou aplicados de forma tópica (PAREKH et al., 1999), e após sua aplicação, há excitação de porfirinas pela luz azul (400nm), verde $(500 \mathrm{~nm})$, ou vermelha $(630 \mathrm{~nm})$, que leva à formação de oxigênio reativo, induzindo a peroxidação de lipídeos e cross-linking de proteínas (BERKING et al., 2007). As formas reativas de oxigênio formadas e os radicais livres são responsáveis pela citotoxicidade induzida pela PDT (DOUGHERTY; MARCUS, 1992). Sabe-se que altas concentrações de espécies reativas de oxigênio causam morte celular por depleção de ATP e peroxidação de lipídeos. Porém, um estudo demonstra que baixas concentrações controladas de oxigênio reativo desempenham 
papel importante na sinalização de diversos pocessos celulares, incluindo a proliferação de fibroblastos (LUBART; FRIEDMANN; LAVIE, 1999).

Uma série de estudos tem mostrado ser possível eliminar bactérias com fonte de luz laser operando em baixa intensidade após estes microorganismos terem sido sensibilizados por uma quantidade mínima de azul de metileno (WILSON; DOBSON; HARVEY, 1992). Além disso, este corante também tem sido utilizado na terapia fotodinâmica de tumores e lesões pré-neoplásicas orais (HIS; ROSENTHAL; GLATSTEIN, 1999).

Pacientes com queilite actínica devem ser tratados de maneira a prevenir a transformação desta em um carcinoma epidermóide. O tratamento de queilite actínica por terapia foto-dinâmica mostra-se bastante eficaz, com taxas de cura entre 70 e $90 \%$ e grande aceitação pelos pacientes, uma vez que não é uma terapia invasiva (MORTON et al., 2002, SZEIMIES et al., 2002). Berking et al. (2007) trataram 15 pacientes acometidos por queilite actínica com PDT. Em seus resultados foi possível observar que houve melhora clínica em $93 \%$ das lesões e, completa melhora clínica em 47\%. Alexiades-Armenakas (2004) tratou 19 pacientes com PDT mediado por ALA, encontrando completa melhora em $47 \%$ dos pacientes após duas sessões da terapia, e em $68 \%$ após 3 sessões.

No entanto, não foi realizado exame histopatológico pós-terapêutico no estudo de Alexiades-Armenakas (2004), enquanto que no estudo de Berking et al. (2007), este exame revelou patologia residual em $62 \%$ dos pacientes.

Hauschild et al. (2005) relatou o caso de três pacientes acometidos por queilite actínica e tratados com PDT mediado por metil-5-amino-4-oxopentanoato (MAOP). Nos três pacientes pôde-se observar boa reposta clínica e estética. Também foi relatada dor moderada a intensa, e tênue inflamação com edema no 
lábio inferior. O autor ainda menciona que a PDT pode ser uma alternativa para os pacientes que não querem ou não podem sofrer intervenção cirúrgica.

A PDT é de fato muito utilizada na terapia de neoplasias (ACKROYD et al., 1999). Sabe-se que os corantes foto-sensibilizantes são mais retidos em células neoplásicas do que em células normais, o que permite a terapia seletiva do tumor em questão (PENG et al., 1997). Além disso, a PDT não apresenta a toxicidade cumulativa da radiação ionizante e pode ser aplicada em tecidos previamente irradiados (LOU et al., 2004), sendo uma alternativa para pacientes com lesões localmente persistentes ou recorrentes após cirurgia ou radioterapia (YANG et al., 2007).

Lou et al. (2004) realizaram tratamento com PDT em 45 pacientes com câncer recorrente de cabeça e pescoço. Nenhum dos pacientes desenvolveu metástase durante o período de acompanhamento. Recentemente, um estudo in vitro avaliou o efeito da PDT mediada por ALA na migração e invasão de linhagens de células de câncer de cabeça e pescoço (YANG et al., 2007). A PDT suprimiu a invasão e migração destas células.

Lisnjak et al. (2005) mostraram a diminuição da angiogênese e metástase de células neoplásicas em camundongos após terapia foto-dinâmica mediada por ALA.

Van Boxem et al. (2001) estudaram o tratamento de câncer intra-luminal em estágio inicial com PDT, comparando-o com o laser de Nd:YAG e eletro-cautério. Os autores observaram a reparação tecidual da parede dos brônquios e, notaram maior formação de cicatriz e maior fibrose sub-epitelial após realização da PDT ou tratamento com Nd:YAG. Estes resultados contrastam com os estudos que apontam a PDT como alternativa para o tratamento de neoplasias em estágio inicial. 
Assim como a LILT, a terapia foto-dinâmica também necessita de ajustes específicos para que se obtenha o resultado desejado. Entre estes ajustes, estão a energia total entregue ao tecido, a densidade de energia e a densidade de potência do aparelho laser utilizado. O tratamento de neoplasias com PDT, empregando baixas taxas de densidade de potência, tem sido demonstrado ao longo dos anos (FOSTER et al., 1991; GIBSON et al., 1990; IINUMA et al., 1995; SITNIK; HAMPTON; HENDERSON, 1998; VAN GEEL et al., 1996).

Sitnik e Henderson (1998) testaram a influência da densidade de potência e também de diferentes densidades de energia na terapia foto-dinâmica de fibrossarcoma induzido por radiação em camundongos. Densidades de potência e energia mais baixas foram mais eficientes, sendo que com uma densidade de $60 \mathrm{~J} / \mathrm{cm}^{2}$ e $10 \mathrm{~mW} / \mathrm{cm}^{2}$ obteve-se a mesma desaceleração de crescimento do tumor obtida com $100 \mathrm{~J} / \mathrm{cm}^{2}$ e $150 \mathrm{~mW} / \mathrm{cm}^{2}$ ou $150 \mathrm{~J} / \mathrm{cm}^{2}$ e $200 \mathrm{~mW} / \mathrm{cm}^{2}$. No entanto, baixas densidades de energia e potência necessitam de tempos de tratamento muito maiores. Os autores também examinaram a toxicidade da PDT ao tecido, relatando maior toxicidade para as altas doses e potências, com maior demora para que o tecido voltasse ao normal.

A PDT também é bastante utilizada na inativação de microorganismos patogênicos (DEMIDOVA; HAMBLIN, 2004; HAMBLIN; HASAN, 2004). Além de ser uma terapia não invasiva, a terapia foto-dinâmica não provocará resistência dos microorganismos, enquanto que uma terapia antibiótica, seja ela tópica ou sistêmica, terá esta desvantagem (COATES et al., 1997; ROSS et al., 2003; WYATT et al., 1977).

Por meio da aplicação local de corante foto-sensibilizante seguida por irradiação com luz, a terapia foto-dinâmica representa uma eficaz alternativa para o 
tratamento de infecções microbianas localizadas, como em uma variedade de infecções orais, queimaduras infectadas, úlceras crônicas e acne vulgaris (JORI et al., 2006).

Infecções de feridas superficiais podem ser tratadas facilmente por terapia foto-dinâmica, uma vez que são acessíveis à aplicação do corante e da luz laser. Queimaduras são particularmente susceptíveis a infecções, devido à destruição da barreira cutânea e ao fato de que proteínas coaguladas e denaturadas são um ambiente nutritivo para o crescimento de bactérias (LAMBRECHTS et al., 2005).

Desta forma, Lambrechts et al. (2005) realizaram feridas por queimadura em camundongos, infectaram-nas com Staphylococcus aureus e trataram-nas com PDT. Mais de $98 \%$ das bactérias foram erradicadas após uma dose de $210 \mathrm{~J} / \mathrm{cm}^{2}$ na presença do corante. No entanto, pôde-se observar novo crescimento das bactérias após a PDT e demora na reparação tecidual destas feridas e daquelas tratadas com apenas a luz laser.

Os autores ainda postulam que a recorrência da infecção em conjunto com a demora na reparação tecidual deve-se ao fato de a PDT causar injúria não somente às bactérias, mas também às células adjacentes do hospedeiro. Assim, torna-se vital a seletividade do corante utilizado ser maior para a bactéria em questão do que para as células e proteínas do hospedeiro.

Em feridas infectadas com uma linhagem não patogênica de Escherichia coli, a PDT foi capaz de eliminar as bactérias, e as feridas tratadas tiveram reparação tecidual tão boa quanto aquelas do grupo controle (HAMBLIN et al., 2002). Em feridas infectadas com uma linhagem altamente patogênica de Pseudomonas aeruginosa, os camundongos tratados com PDT não sofreram septicemia e morte 
como os outros pertencentes aos grupos que receberam apenas o corante ou a irradiação laser (HAMBLIN et al., 2003).

Diferentemente daquilo observado no estudo de Lambrechts et al. (2005), no estudo de Hamblin et al. (2003), as feridas tratadas com PDT tiveram reparação tecidual acelerada, o que foi atribuído à destruição de fatores de virulência extracelulares secretados pela bactéria e que são responsáveis por atraso na reparação tecidual.

Com relação à herpes labial, o tratamento mais comunente aceito para esta patologia é aquele baseado em drogas antivirais, como o acyclovir. No entanto, sabe-se que esta droga mostra bons resultados apenas se aplicada previamente à formação das vesículas (FIDDIAN et al., 1983).

Em um estudo realizado por Sperandio et al. (2009), foram detectados bons resultados com PDT mediado por azul de metileno em pacientes que já apresentavam vesículas formadas. Além disso, a aplicação tardia de uma outra droga antiviral, o penciclovir, pode ainda trazer algum benefício (FIFE et al., 1997). Porém, sua aplicação deve acontecer de duas em duas horas (RABORN et al., 2002; SPRUANCE et al., 1997), enquanto o PDT pode ser ministrado em sessão única (SPERANDIO et al., 2009).

\subsection{Terapia foto-dinâmica em reparação tecidual}

Como mencionado anteriormente, existem vários estudos mostrando o significativo efeito da irradiação laser na reparação tecidual de animais (ABERGEL 
et al., 1987; BAXTER; BELL; ALLEN; 1992; DYSON; YOUNG, 1986; LYONS et al., 1987; MASHIKO; SHIMAMOTO; INABA, 1983; ROCHKIND et al., 1989). Vários aparelhos, emitindo luzes de diversos comprimentos de onda vermelhos ou infravermelhos, estão hoje disponíveis no mercado.

No entanto, não há muitos estudos sobre o efeito desta luz laser quando combinada ao uso de corantes foto-sensibilizadores na reparação tecidual de feridas.

Silva et al. (2004) avaliaram o efeito da PDT na reparação tecidual de lesões provocadas por um punch em dorso de ratos. Os autores puderam notar um efeito sinérgico entre a irradiação laser e o corante foto-sensibilizador utilizado. Além disso, os autores afirmam que o efeito antimicrobiano provocado pela PDT é um ponto positivo para a reparação tecidual, sendo que pode não apenas ajudar na aceleração da reparação tecidual, mas também pode agir de maneira a evitar infecções locais durante o processo reparacional.

Estudos preliminares realizados por Stern et al. (1990) e Jefferis, Chevretton e Berenbaum (1991) em modelos animais, demonstraram que a PDT tem papel significativo na reparação tecidual, incluindo aumento da formação do tecido de granulação primário, mais rápida re-epitelização e redução da necrose de fibras musculares, tecido mucoso e inflamação. Nos estudos realizados de forma a avaliar o efeito da PDT na matriz extra-celular, observou-se que as características biológicas inerentes à matriz foram profundamente alteradas e o crescimento de células de músculo liso foi profundamente inibido, enquanto que o crescimento de células endoteliais foi estimulado na matriz alterada pela PDT (STATIUS et al., 1997). 
Como a PDT é considerada um tratamento coadjuvante para diminuir a recorrência de neoplasias de cabeça e pescoço, preocupa-se com as implicações desta terapia na reparação tecidual, principalmente em retalhos mio-cutâneos, que são muito utilizados nas cirurgias de reconstrução após ressecção de câncer de cabeça e pescoço. Assim, Kübler et al. (1996) realizaram um estudo em ratos, onde um retalho cirúrgico era tratado ou não com PDT. Os grupos controle, e aqueles que tomaram contato apenas com o corante foto-sensibilizador ou apenas a luz laser, mostraram uma reparação tecidual normal, além de não mostrarem diferenças entre si com relação aos ensaios mecânicos de tração da ferida. O grupo tratado com PDT, no entanto, mostrou necrose epitelial acentuada e menor resistência mecânica da ferida. Os autores concluíram que a PDT, quando realizada imediatamente antes do reposicionamento do retalho, resulta em atraso na reparação tecidual.

Os radicais livres liberados pela PDT podem interferir com as proteínas da matriz extra-celular, especificamente o TGF- $\beta$ (transforming growth factor- $\beta$ ), que pode levar a diversos efeitos em diferentes tipos celulares (PAREKH et al., 1999).

Parekh et al. (1999) avaliaram a reparação tecidual decorrente da terapia fotodinâmica mediada por um corante derivado da benzoporfirina (BPD-MA) e sulfoptalocianina de cloro e alumínio (CASP) e realizada em feridas provocadas em pele de ratos. Eritema, edema, inflamação e necrose atribuídas ao PDT foram observados, porém a PDT não influenciou na aparência final das feridas. Os resultados permitiram aos autores concluir que uma única dose de PDT no processo de reparação tecidual é pouco influente ou transitória. É também possível que o modelo de ferida incisional utilizado no estudo não tenha sido representativo dos 
efeitos decorrentes da PDT e que múltiplas doses em tempos variados possam se provar mais eficazes em alterar a reparação tecidual ou formação de cicatrizes.

Orringer et al. (2008) examinaram quantitativamente as mudanças moleculares decorrentes da terapia foto-dinâmica em pele humana. Os autores concluíram que a PDT, empregada através de regime específico, produz mudanças estatisticamente significantes, como produção de colágenos I e III, que estão associados a melhor aparência da pele. Também observaram que a PDT pode levar a um aumento da remodelação da derme se comparado à aplicação simples de laser. No estudo de Silva et al. (2004), os animais tratados com PDT e laser apresentaram maior quantidade de colágeno e mais rápida re-epitelização quando comparados ao grupo controle e grupo que recebeu apenas aplicação de corante.

Jayasree et al. (2001) avaliaram o efeito da PDT na reparação tecidual em ratos, utilizando os aparelhos de $\mathrm{He}-\mathrm{Ne}\left(3 \mathrm{~J} / \mathrm{cm}^{2}\right)$ e $\mathrm{Nd}: Y A G\left(30 \mathrm{~J} / \mathrm{cm}^{2}\right)$, em combinação com os foto-sensibilizadores ALA e derivado de hematoporfirina (HPD). Os autores mencionam que fatores sistêmicos decorrentes da irradiação laser podem existir, afetando áreas não-irradiadas. Por isso, é importante que seja feito um controle de feridas não-irradiadas em animais distintos, e não nos mesmos que receberam a irradiação laser ou a PDT.

Os resultados de seu estudo sugerem que a PDT acelera a reparação tecidual em ratos, sendo que o ácido 5-aminolevulínico combinado com o laser de He-Ne teve o resultado mais satisfatório, com completo fechamento da ferida aos treze dias de pós-operatório, enquanto que o grupo controle obteve fechamento completo apenas aos dezenove dias. O uso combinado do derivado de hematoporfirina com ambos os lasers de Nd:YAG e He-Ne também mostraram resultados promissores na reparação tecidual. No entanto, quando o ALA foi usado 
como foto-sensibilizador em combinação com ambos os lasers, o processo de reparação tecidual apresentou demora entre o décimo terceiro e décimo sétimo dias de pós-operatório.

\subsection{Citoqueratinas}

A epiderme atua como uma barreira física e impermeável, essencial para a sobrevivência e adaptação dos mamíferos à vida terrestre (KALININ; MAREKOV; STEINERT, 2001; STEINERT; MAREKOV, 1995; STEVEN; STEINERT, 1994). Esta barreira que impede a entrada de substâncias exógenas e organismos e previne a perda de fluidos vitais, é feita e continuamente regenerada pelos queratinócitos. Estas células, por sua vez, são responsáveis pela diferenciação epitelial, que tem início com a migração dos queratinócitos da camada basal e finaliza-se com a formação da camada córnea (CANDI; SCHIMIDT; MELINO, 2005).

O citoesqueleto dos queratinócitos é constituído, dentre outros elementos, por citoqueratinas diversas, que fazem parte do grupo de filamentos de tamanho intermediário (7 a 12 nm de comprimento) (COULOMBE; OMARY, 2002).

Estas citoqueratinas constituintes do citoesqueleto das células epiteliais também são denominadas queratinas moles, sendo diferentes das queratinas duras que formam a haste do cabelo e a unha (LANGBEIN et al., 1999).

As citoqueratinas são atualmente divididas em dois grupos: as do tipo I, ácidas, incluindo as citoqueratinas de 9 a 23 , e as do tipo II, básicas, incluindo as de número 1 a 8 (COULOMBE; OMARY, 2002). 
Todas as citoqueratinas têm uma molécula semelhante, constituída por quatro segmentos helicoidais - 1A, 1B, 2A, 2B - intercalados por segmentos curtos não helicoidais, chamados de segmentos ligantes L1, L12 e L2 (Figura 2.1). Na extremidade, encontram-se os segmentos variáveis $\mathrm{V} 1$ e $\mathrm{V} 2$, sendo que as citoqueratinas básicas apresentam segmentos $\mathrm{H} 1$ e $\mathrm{H} 2$ entre os helicoidais e os variáveis (COULOMBE; OMARY, 2002; SMITH, 2003; ISHIDA-YAMAMOTO; TAKAHASHI; LIZUKA, 2002).

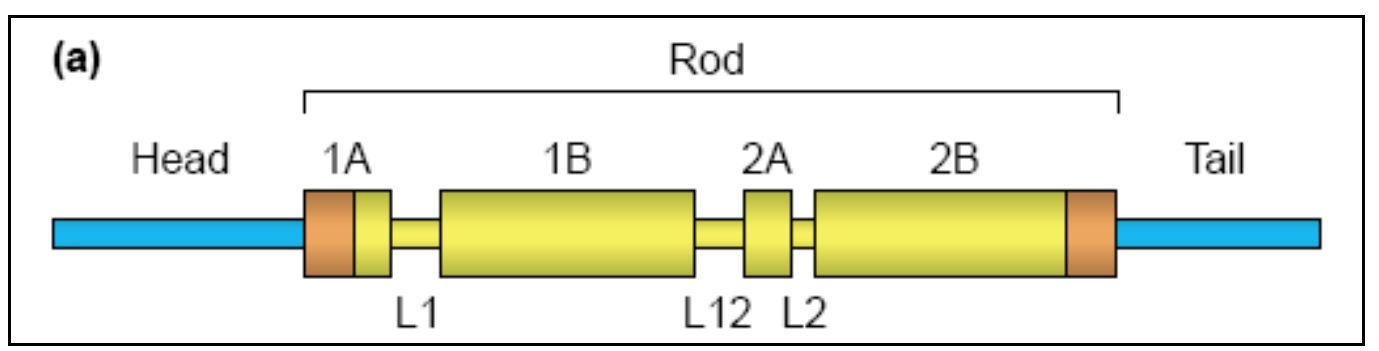

Figura 2.1 - Estrutura de citoqueratina com domínio central (rod) constituído por segmentos helicoidais (1A, 1B, 2A e 2B) separados por segmentos não helicoidais (L1, L12 e L2). Nas extremidades amina e carboxila encontram-se os segmentos não helicoidais head e tail, respectivamente (COULOMBE; OMARY, 2002)

$\mathrm{Na}$ maioria das vezes, as citoqueratinas são encontradas aos pares, formando heterodímeros. Ou seja, há a união de duas citoqueratinas distintas, constituindo filamentos, que são a estrutura tridimensional formadora do citoesqueleto e ancoram-se nos desmossomos e na placa interna dos hemidesmossomos (ALMEIDA, 2004).

As citoqueratinas (CKs) 5 e 14 são as principais proteínas estruturais nos queratinócitos basais em proliferação. Através de sinais ainda pouco esclarecidos, os queratinócitos basais migram para a camada espinhosa, perdem sua atividade mitótica e começam a sintetizar uma nova série de proteínas estruturais e enzimas 
características da queratinização (corneificação), entre elas as citoqueratinas 1 e 10 . (CANDI; SCHIMIDT; MELINO, 2005).

As diversas citoqueratinas são expressas através de específicos grupos de polipeptídeos característicos de determinados tipos celulares e, portanto, permitem com que possamos distinguir e classificar as células epiteliais de acordo com seu padrão expresso de citoqueratinas (MOLL et al., 1982a). Por exemplo, o epitélio não-estratificado do tubo digestivo e seus órgãos associados (pâncreas e fígado, por exemplo) são caracterizados por uma composição de citoqueratinas bastante simples, contendo de dois a quatro polipeptídeos principais, como as CK8 e CK18. Estes dois tipos de citoqueratinas parecem ser as primeiras expressas durante a embriogênese (JACKSON et al., 1980; JACKSON et al., 1981).

O epitélio da traquéia contém tanto as citoqueratinas de natureza básica quanto os polipeptídeos 7, 8, 18 e 19. Já a epiderme e diversos outros epitélios estratificados, não apresentam os tipos de CKs expressas nos epitélios simples do trato digestivo, expressando uma variedade de outras citoqueratinas básicas e ácidas.

O problema de se relacionar determinado tipo celular a seus padrões expressos de CKs é o da heterogeneidade de vários tecidos epiteliais. O epitélio das glândulas mamárias, por exemplo, consiste de no mínimo três tipos distintos de células (células mioeoepiteliais, ductais e células secretoras) que contêm diferentes tipos de polipeptídeos de citoqueratinas, uma vez que já mostraram exibir diferentes determinantes antigênicos em seus filamentos de citoqueratinas (ASCH et al., 1981; FRANKE et al., 1980; KREPLER et al., 1981). Ainda mais complexa é a pele, na qual já foram identificados sete tipos celulares a partir de seus padrões de 
citoqueratinas, incluindo células do folículo piloso, glândulas sebáceas e sudoríparas (MOLL et al., 1982a, b).

A complexidade dos padrões de citoqueratinas também mostra grandes diferenças em relação a tumores. Em geral, tumores derivados de tecido epitelial mantêm seus padrões de polipeptídeos de citoqueratinas expressos em suas células normais, antes de sofrerem mutações (MOLL et al., 1982a; MOLL; KREPLER; FRANKE, 1983). Em alguns casos, os polipeptídeos de citoqueratinas encontrados no tecido epitelial normal que deu origem a determinado tumor, não são encontrados no tumor originado. Isto pode ser explicado pela ausência da expressão de citoqueratinas que são típicas do estrato superior de epitélio, no caso de epitélio estratificado, em tumores de pele, língua e esôfago (MOLL et al., 1982a; MOLL; KREPLER; FRANKE, 1983). Estas diferenças encontradas também podem refletir seleção, durante a transformação epitelial e desenvolvimento do tumor. Assim, pode haver casos de neoplasias cuja expressão de polipeptídeos de citoqueratina difere daquela encontrada no tecido do qual a neoplasia se originou (MOLL et al., 1982a; MOLL; KREPLER; FRANKE, 1983).

Alguns trabalhos têm mostrado o comportamento de ratos que tiveram genes de queratina inativados através da técnica de gene knockout. O gene da citoqueratina 8 (CK8) foi o primeiro a ser inativado por esta técnica (BARIBAULT et al., 1993). A partir de então, um grande número de genes de queratina foram estudados pelo mesmo método.

Como observado antes para camundongos cujos genes de CK 14 foram inativados (LLOYD et al., 1995), camundongos sem o gene de CK 5 demonstraram sérias úlceras tanto em pele quanto em mucosa oral e morreram brevemente após o nascimento (PETERS et al., 2001). As células basais isentas de CK 5 não exibem 
qualquer filamento intermediário e são extremamente sensíveis ao trauma (COULOMBE; OMARY, 2002).

A citoqueratina 10 (CK 10) é a principal citoqueratina expressa nas camadas em diferenciação da epiderme e em outros epitélios queratinizados. No entanto, os camundongos isentos de CK 10 não apresentam qualquer anormalidade de pele antes de seis semanas após o nascimento, provavelmente devido a um aumento nos níveis de CK5 e CK14 (REICHELT et al., 2001). Apesar de mais análises se fazerem necessárias, estes achados mostram a existência de uma redundância quando se trata da função desempenhada pelas citoqueratinas mais expressas na epiderme (COULOMBE; OMARY, 2002).

Sabe-se que mutações relativas aos genes de queratina causam sérias doenças relacionadas à mucosa oral, óptica e pêlos (IRVINE; MCLEAN, 1999). Estas doenças são bem definidas geneticamente e são, tipicamente, autossômicas dominantes, embora exista uma pequena parcela recessiva. Em geral, a severidade da doença está relacionada ao local e natureza da mutação (LIOVIC et al., 2001).

As patologias relacionadas à incorreta ou falta de expressão das citoqueratinas em humanos, realçam a idéia de super-expressão compensatória de outras citoqueratinas (já descritas em camundongos isentos de determinados genes de queratinas) como um fator de atenuação da doença (COULOMBE; OMARY, 2002). A pele de um indivíduo acometido por epidermólise bolhosa recessiva simples, por exemplo, que resulta em ausência de CK14, tem expressão elevada de CK15 (JONKMAN et al., 1996).

A regulação das citoqueratinas pode ocorrer intrinsicamente via interações próprias (COULOMBE; OMARY, 2002) ou extrinsicamente via interação/associação com proteínas não-queratinas que resultam em fosforilação, glicosilação, 
transglutaminação, ubiquitinização, clivagem proteolítica ou associação com outros elementos do citoplasma ou citoesqueleto (COULOMBE et al., 2000; OMARY et al., 1998). A importância das proteínas associadas às citoqueratinas (KAPs - Keratin Associated Proteins) é amplamente suportada pelas doenças relacionadas com as proteínas ligadoras plectina, plakofilina 1 e desmoplaquina (FUCHS; KARAKESISOGLOU, 2001; GREEN; GAUDRY, 2000; STEINBOCK et al., 2000). Estas proteínas ligadoras ajudam a conectar os filamentos de queratina aos hemidesmossomos, desmossomos e outros elementos do citoesqueleto (FUCHS; KARAKESISOGLOU, 2001; HATZFELD et al., 2000; SHI; SUGRUE, 2000; STEINBOCK et al., 2000). Outras KAPs incluem as proteínas ligantes filagrina e tricohialina (COULOMBE et al., 2000); moléculas sinalizadoras, como as proteínas 14-3-3 (KU; LIAO; OMARY, 1998) e o receptor TNF tipo 2 (CAULIN et al., 2000); outras enzimas como a RNA polimerase II (BRUNO et al., 1999) e chaperonas como a Hsp70 (KU et al., 1999).

Embora ainda existam dúvidas com relação às funções das KAPs, determinadas conclusões podem ser tomadas. As KAPs ajudam a manter a estabilidade mecânica das células e a regular a organização dos filamentos de queratina nas células em cultura (FUCHS; KARAKESISOGLOU, 2001; IZAWA et al., 2000; STEINBOCK et al., 2000). As queratinas também parecem ser importantes na modulação de resposta apoptótica, sendo que sua ausência (CAULIN et al., 2000) leva a um dramático aumento na apoptose, atraindo os receptores TNF ou Faz, possivelmente via uma interação ou modulação entre estes receptores. Embora as KAPs regulem queratinas, as queratinas, por sua vez, regulam as KAPs em termos de sua disponibilidade. Regular a disponibilidade de proteínas como a Hsp70 e 14-33 pode ser vantajoso para a célula, especialmente se esta regulagem é dada por 
fosforilação (KU et al., 1999). Assim, embora citoqueratinas claramente desempenhem uma função mecânica importante, elas também desempenham diversos outros papéis "não-mecânicos" (COULOMBE; OMARY, 2002).

Os filamentos intermediários, de forma geral, interagem com outros componentes celulares, como a membrana plasmática, o envelope nuclear, mitocôndrias e outras estruturas do citoesqueleto, incluindo os microtúbulos e filamentos de actina (SVITKINA; VERKHOVSKY; BORISY, 1996). Estas ligações podem ser indiretas, via proteínas cross-linking como a plectina ou sinemina, ou diretas, por meio da ligação das proteínas dos filamentos intermediários com componentes protéicos de outras estruturas celulares (BELLIN et al., 2001). A plectina é expressa em uma variedade de tecidos e células de mamíferos (WICHE, 1998). A plectina interage com várias estruturas do citoesqueleto e proteínas deste (WICHE, 1998). Esta proteína pode ter desde 2 a $3 \mathrm{~nm}$ de comprimento até $200 \mathrm{~nm}$ e realiza uma ponte entre a vimentina e os microtúbulos e filamentos de actina (SVITKINA; VERKHOVSKY; BORISY, 1996).

A sinemina foi inicialmente descrita como uma proteína associada a filamentos intermediários (IFAP - IF- associated protein) (OLIVE et al., 2003). A sinemina atua como um componente dos filamentos intermediários e auxilia estes a se ligarem a outras estruturas do citoesqueleto (OLIVE et al., 2003). A plectina e sinemina têm importante papel na organização do citoesqueleto dos hepatócitos, atuando como uma rede firme e estável que mantém o tamanho e a forma uniformes destas células (HO et al., 2004; WICHE, 1998).

Existem poucos estudos recentes mostrando a expressão das citoqueratinas durante a re-epitelização de feridas em pele de humanos (KUROKAWA; MIZUTANI; 
KUSUMOTO, 2006), sendo a maioria dos estudos realizados há mais de 50 anos (EISEN; HOLYOKE; LOBITZ, 1955; LOBITZ; HOLYOKE; MONTAGNA, 1954).

O processo pelo qual feridas sofrem re-epitelização é ainda controverso. Dois modelos têm sido propostos para explicá-lo: o modelo de deslizamento (sliding) e o de rolamento (rolling). Enquanto no modelo de deslizamento os queratinócitos basais são as principais células envolvidas na migração e fechamento da ferida, no modelo de rolamento, as principais células envolvidas são os queratinócitos suprabasais da margem da ferida, que "rolam" até o local da injúria (USUI et al., 2005).

Muitos estudos defendem o modelo de deslizamento (CARTER et al., 1990; CROFT; TARIN, 1969; DAVIDSON, 1998; MARTINEZ, 1972; ODLAND; ROSS, 1968; POLLACK, 1979; RADICE, 1980; SMITH; DEAN, 1998; VAUGHAN; TRINKAUS, 1966; WOODLEY, 1996; WOODLEY et al., 1999), enquanto outros defendem o de rolamento (GARLICK, 2004; GARLICK; TAICHMAN, 1994; KRAWCZYK, 1971; KRAWCZYK, 1972; LAPLANTE et al., 2001; MANSBRIDGE; KNAPP, 1987; ORTONNE et al., 1981; SCIUBBA, 1977; WINTER, 1972). Assim, esta controvérsia demanda esclarecimento (MARTIN, 1997; PANG; DANIELS; BUCK, 1978; STENN; DE PALMA, 1988; STENN; MALHOTRA, 1992).

As evidências que suportam a teoria de rolamento têm sido baseadas na avaliação morfológica por microscópio eletrônico de varredura, de transmissão e imunoistoquímica. Segundo esta teoria, os queratinócitos basais expostos ao ambiente no qual ocorreu a ferida, sofrem transformação do formato celular, têm suas ligações com desmossomos reduzidas e "tombam" sobre os queratinócitos basais que permanecem firmemente ancorados à membrana basal (USUI et al., 2005). 
Já de acordo com a teoria de deslizamento, após a injúria sofrida, os queratinócitos basais apresentam mudanças em suas ligações com hemidesmossomos. Isto permite com que estas células se desliguem da zona da membrana basal, degradem matriz extracelular, depositem novos componentes da membrana basal como laminina 5, e migrem lateralmente para a matriz provisória da ferida. As evidências que suportam esta teoria baseiam-se em estudos in vitro (USUI et al., 2005).

Alguns trabalhos mostram que queratinócitos em cultura assemelham-se à epiderme in vivo quanto à capacidade de regenerar as camadas suprabasais após injúria. Além disso, a resposta mitótica destas células in vitro, mostrou-se semelhante à resposta delas in vivo (JENSEN; BOLUND, 1988; READ; WATT, 1988). No entanto, há várias diferenças quando se compara o padrão da expressão de genes de queratinócitos in vitro com a daquela da epiderme humana intacta (JENSEN et al., 1991). Assim, torna-se melhor usar o modelo in vivo para estudar o processo de re-epitelização durante a reparação tecidual (WATANABE et al., 1995).

Watanabe et al. (1995) estudaram a expressão de citoqueratinas ocorrida ao longo da reparação tecidual em pele do dorso de porquinhos-da-índia. Os autores observaram que os queratinócitos que migraram da epiderme remanescente à margem da ferida expressaram as mesmas citoqueratinas expressas pelos queratinócitos da camada basal de pele normal. Neste estudo, os queratinócitos que expressaram as mesmas citoqueratinas que os queratinócitos basais, migraram do topo da ferida, eventualmente cobriram a ferida e eliminaram o tecido necrótico.

O fato de ser encontrado o mesmo padrão de CKs nos queratinócitos em migração e na camada basal da epiderme, é compatível com a idéia de que apenas 
os queratinócitos basais se dividem e proliferam em epiderme normal (WATANABE et al., 1995).

No entanto, existem outros estudos mostrando que são os queratinócitos da camada suprabasal, e não os basais, que migram através de rolamento ou deslizamento por sobre a camada basal (BEERENS; SLOT; VAN DER LEUN, 1975; GIBBINS, 1978; KRAWCZYK, 1971; SCIUBBA, 1977; WINTER, 1972).

Ainda no estudo realizado por Watanabe et al. (1995), pôde-se observar que as CKs expressas em queratinócitos normais da camada basal foram também expressas em áreas remotamente distantes das bordas das feridas, onde não foi encontrada proliferação de queratinócitos. Um padrão similar de marcação foi encontrado em áreas distantes das margens das feridas em um estudo realizado por Mansbridge e Knapp (1987).

Durante a regeneração da epiderme, as células da camada supra-basal expressaram temporariamente CKs específicas não apenas para células suprabasais, como também específicas para células da camada basal (WATANABE et al., 1995). Além disso, tanto na epiderme remanescente das bordas da ferida quanto na epiderme recém-formada, foi observado adelgaçamento das camadas granular e espinhosa. As CKs expressas nos queratinócitos basais normais estavam presentes nas camadas granulosas tanto na epiderme em regeneração quanto na epiderme remanescente das bordas da ferida, onde a camada granulosa fina apresentava grânulos de queratohialina. Os autores concluíram que o aparecimento de grânulos de queratohialina na camada granulosa foi um evento independente das mudanças na expressão de CKs (WATANABE et al., 1995).

Quando se trata de reparação tecidual, as citoqueratinas desempenham papel muito importante. Após determinada injúria, o equilíbrio normal entre a proliferação, 
adesão e diferenciação de CKs é perdido. As CKs adjacentes à recém-formada ferida devem responder rapidamente de forma a reparar o defeito. E após o fechamento da ferida, as citoqueratinas terminam sua diferenciação (USUI et al., 2005).

Kurokawa, Mizutani e Kusumoto (2006) estudaram a expressão de citoqueratinas na reparação tecidual de diversos tipos de úlceras cutâneas, incluindo as diabéticas e por queimadura. Os autores observaram imuno-positividade para citoqueratinas 14, 16 e 17 nas bordas da ferida e língua epiteliais. As expressões das citoqueratinas 1 e 10 encontraram-se diminuídas nas bordas das feridas, como previamente reportado (KALLIOINEN et al., 1995; WATANABE et al., 1995). O imuno-fenótipo da expressão das citoqueratinas na borda das feridas é, portanto, um fenótipo ativo. E é, de alguma forma, diferente daquele encontrado em células basais da epiderme normal (KUROKAWA; MIZUTANI; KUSUMOTO, 2006). A expressão das citoqueratinas nas bordas da ferida é similar àquela da outer root sheat, que é mais hiper-proliferativa e indiferenciada (KUROKAWA et al., 2003).

Usui et al. (2008) estudaram a expressão de citoqueratinas nos queratinócitos existentes em feridas cutâneas incisionais e excisionais em pacientes normais e em úlceras crônicas em diabéticos. Os autores relataram padrões bastante diferentes na expressão das CK14, CK10 e CK2 entre as úlceras normais e diabéticas. Nas incisões normais, a expressão da CK14 limitou-se à camada basal e a algumas células da camada supra-basal imediatamente adjacentes à matriz da ferida, quando examinadas em um dia de pós-operatório. Aos dois dias após injúria, todo o epitélio novo da ferida expressava a CK14 e este padrão persistiu até os quatorze dias de pós-operatório. Vinte e oito dias após realização da ferida, a CK14 era expressa 
apenas nos queratinócitos basais encontrados ao longo da junção derme-epiderme, como já havia sido mostrado anteriormente (USUI et al., 2005).

No mesmo estudo, todas as camadas de queratinócitos da língua epitelial das feridas de pacientes com diabetes expressavam a CK14, similarmente às feridas excisionais aos dois e sete dias de pós-operatório. Foi observada expressão de CK2 e CK10 na língua epitelial de feridas em indivíduos normais nas primeiras quarenta e oito horas.

Notou-se que se a língua epitelial tem um caminho mais longo a percorrer, e não consegue fechar em 48 ou 72 horas (como acontece nas feridas excisionais), a expressão de CK2 e CK10 deixa de existir na porção central do novo epitélio. Isto já havia sido relatado pelo mesmo autor em estudo prévio (USUI et al., 2005). É um padrão similar àquele observado em úlceras crônicas de pacientes diabéticos.

\section{$2.7 \mathrm{p} 63$}

A proteína p63 é codificada pelo mesmo gene que as proteínas p53, e p73. Diferentemente de outros supressores de tumor, o gene p53 não tinha homólogos conhecidos até a descoberta do p73 em 1997, e do p63 em 1998 (AUGUSTIN et al., 1998; OSADA et al., 1998; YANG et al., 1998). As três proteínas apresentam estruturas similares, sendo p63 e p73 mais semelhantes entre si do que com o p53 (SACCONE et al., 2002; YANG et al., 2002), mas apresentam funções diferentes (BARBIERI; PIETENPOL, 2006). 
O gene humano do p63 reside no cromossomo 3q27-29, e consiste de 15 exons, e íntrons de até 100kB de comprimento (BARBIERI; PIETENPOL, 2006). O p63 possui isoformas que contém (TAp63) ou não contêm $(\Delta N p 63)$ um domínio de transativação (transactivation domain). As isoformas TAp63 têm função nos estágios iniciais da morfogênese da epiderme, enquanto que as isoformas $\Delta N p 63$ são predominantemente expressas nos estágios finais da mesma (KOSTER et al., 2004; LAURIKKALA et al., 2006). As $\Delta$ Np63 são ainda as isoformas predominantes na epiderme madura (LIEFER et al., 2000; YANG et al., 1998). Elas são expressas principalmente em queratinócitos da camada basal em proliferação e têm sua expressão diminuída por down-regulation nos queratinócitos das camadas suprabasais já diferenciadas da epiderme madura (PARSA et al., 1999; YANG et al., 1998).

A $\Delta \mathrm{Np63 \alpha}$ é a isoforma de $\Delta \mathrm{Np63}$ predominante na pele madura, enquanto as isoformas $\Delta N p 63 \beta$ e $\Delta N p 63 y$ não são detectáveis (LIEFER et al., 2000; YANG et al., 1998).

O p63 é um marcador essencial das células basais progenitoras da epiderme e de seus anexos (TSUJITA- KYUTOKU et al., 2003), da mucosa oral, do epitélio de transição encontrado na bexiga de glândulas como a próstata, as glândulas salivares, mamárias e lacrimais (DELLAVALLE et al., 2001; DI COMO et al., 2002; YANG et al., 1998). O p63 está relacionado com a proliferação celular e migração durante a reparação tecidual (TSUJITA- KYUTOKU et al., 2003).

A morfogênese da epiderme finaliza-se com a formação da epiderme madura que protege o organismo da desidratação e agressões provenientes do meio externo (DAl; SEGRE, 2004). Esta morfogênese depende da ação seqüencial e coordenada de determinados fatores de transcrição e, durante todo o processo, podem ser 
notadas duas transições principais: o início da estratificação, quando células do ectoderma de camada simples são induzidas a se transformarem em queratinócitos; e a diferenciação terminal destas células (KOSTER et al., 2007).

O p63 é um gene crucial para o controle da morfogênese da epiderme. Isto pode ser comprovado pelo fenótipo de camundongos que não expressam o gene do p63. Estes animais não são capazes de produzir epiderme ou outro epitélio estratificado, e nem mesmo anexos cutâneos (MILLS et al., 1999; YANG et al., 1999). Assim, o p63 parece ser fundamental para a diferenciação e especialização das células epiteliais que formam o epitélio estratificado (REIS-FILHO et al., 2002).

Estudos mais antigos sugerem que o p63 tenha participação na manutenção da população de células-tronco epiteliais (PELLEGRINI et al., 2001; YANG et al., 1999). No entanto, outros estudos mostraram que células-tronco epidermais não apresentam maior expressão de p63, o que contradiz os trabalhos anteriores (LARDERET et al., 2006; MORRIS et al., 2004; OHYAMA et al., 2006; TUMBAR et al., 2004).

Assim, o papel exato desempenhado pelo p63 na morfogênese da epiderme não é compreendido. Sabe-se, porém, que quando este gene é retirado de camundongos, a epiderme dos mesmos torna-se de camada simples e incapaz de promover uma barreira física, resultando na morte destes animais brevemente após o nascimento, devido à severa desidratação (KOSTER et al., 2007).

Koster et al. (2007) geraram camundongos cuja expressão das isoformas $\Delta \mathrm{Np63}$ foi inibida especificamente na epiderme. Os autores observaram que este procedimento causou defeitos severos na epiderme, incluindo diferenciação terminal imperfeita e formação de membrana basal imperfeita, levando à formação de úlceras na pele. Além disso, enquanto os animais do grupo controle tiveram suas feridas 
completamente reparadas após 96 horas, as úlceras apresentadas pelo grupo experimental foram incapazes de se repararem, mostrando apenas uma formação marginal da língua epitelial.

O gene do p63 apresenta-se frequentemente mutado em uma série de displasias ectodérmicas humanas, caracterizadas por anomalias de cabelo, dentes, unhas, glândulas mamárias e sudoríparas (BRUNNER; HAMEL; BOKHOVEN, 2002). Desta forma, tais acontecimentos em humanos estão de acordo com aqueles descritos para os camundongos que não expressam o gene do p63 (KOSTER et al., 2004).

Vários estudos têm sido efetuados em relação à expressão de p63 em neoplasias. Carcinomas epidermóides de diversos órgãos expressam altos níveis de p63 (CHOI et al., 2002; CROOK et al., 2000; DI COMO et al., 2002; HIBI et al., 2000; PARK et al., 2000; REIS-FILHO et al., 2003; REIS-FILHO et al., 2002; WEBER et al., 2002; YAMAGUCHI et al., 2000).

A superexpressão de p63 encontrada nos carcinomas epidermóides sugerem algum papel deste gene na carcinogênese (KOSTER; ROOP, 2004). E enquanto as isoformas $\Delta$ Np63 são apontadas por terem função oncogênica (LIEFER et al., 2000; PATTURAJAN et al., 2002), as isoformas TAp63 podem ter habilidades de supressão de tumor (DOHN; JIANG; CHEN, 2001; DOHN; ZHANG; CHEN, 2001; FLORES et al., 2002; OKADA et al., 2002; SASAKI et al., 2001). Além disso, outros estudos mostram que as isoformas $\Delta N p 63$ podem agir de forma a inibir a ação apoptótica de p53, TAp63 e TAp73 (LIEFER et al., 2000; RATOVITSKI et al., 2001; YANG et al., 1998). No entanto, Koster e Roop (2004) mencionam o fato de que, como o p63 tem papel em manter o potencial proliferativo de queratinócitos basais, é 
possível que assim como as isoformas $\Delta$ Np63, as TAp63 também desempenhem função oncogênica.

Kurokawa, Mizutani e Kusumoto (2006) estudaram a reparação de feridas decorrentes de diversas patologias em humanos. Em seus resultados, pôde ser observada imuno-positividade para p63 nas células basais, parabasais e língua epitelial durante o processo de reparação tecidual. Este padrão de marcação já havia sido previamente reportado na reparação tecidual de feridas cutâneas em humanos (NOSZCZYK; MAJEWSKI, 2001).

Bamberger et al. (2005) estudaram a distribuição local e temporal de TAp63a, TAp63 $\beta, \Delta$ Np63a e $\Delta$ Np63 $\beta$ em feridas excisionais realizadas no dorso de ratos. Os autores encontraram as quatro isoformas de p63 durante todos os estágios da reparação. No entanto, as isoformas de TAp63 foram expressas em níveis muito menores do que as isoformas $\Delta$ Np63. Esta diferença na expressão das isoformas sugere que tenham papéis diferentes ao longo do processo reparacional.

Reis-Filho et al. (2002) descreveram a expressão de p63 em epiderme normal, anexos cutâneos, carcinoma epidermóide in situ, carcinoma epidermóide invasivo e carcinoma de células basais. Neste estudo, foi observado forte expressão de p63 nas células basais e ocasionalmente em células supra-basais, e falta de expressão nas camadas mais superficiais da epiderme. $O$ mesmo padrão foi observado nos carcinomas. A perda gradual de expressão do p63 a partir das células basais até as células que sofreram diferenciação terminal já havia sido demonstrada em outros estudos (DE LAURENZI et al., 2000; PARSA et al., 1999; PELLEGRINI et al., 2001).

Como o p63 é um marcador dos queratinócitos com potencial proliferativo alto, Noszczyk e Majewski (2001) estudaram sua expressão em conjunto com outro 
marcador de proiferação celular, o Ki67, durante a regeneração normal da epiderme de humanos. Os autores relataram que nos primeiros dias observados, a expressão de $\Delta$ Np63 e Ki67 foi fraca na área da língua epitelial que invadia a crosta. Já aos cinco dias após a injúria, a expressão de $\Delta \mathrm{Np63}$ em queratinócitos basais era detectada, aumentando gradualmente ao longo dos dias. Vários dias após o fechamento das feridas, a expressão de $\Delta \mathrm{Np63}$ ainda era bastante forte nos queratinócitos basais e também em toda a camada espinhosa do epitélio. Os resultados sugerem que $\Delta \mathrm{Np63}$ está envolvida no controle da proliferação e migração celular envolvidos na reparação tecidual da pele de humanos. 


\section{PROPOSIÇÃO}

A proposta do presente estudo foi avaliar a reparação tecidual em feridas cirúrgicas realizadas com punch em dorso de ratos após terem estas sido irradiadas com laser em baixa intensidade ou tratadas com terapia foto-dinâmica mediada por corante azul de metileno, observando os diferentes estágios da reparação tecidual por meio da análise morfológica e histo-morfológica da reparação e expressão imunoistoquímica de citoqueratinas 10 e 14 e p63. 


\section{MATERIAL E MÉTODOS}

\subsection{Material}

\subsection{1 animais}

Foram utilizadas 100 (cem) ratas fêmeas, adultas (Rattus Novergicus Albinus, variedade Wistar), com massa corporal média de $250 \mathrm{~g}$ e idade média de 100 dias, provenientes do biotério do Departamento de Materiais Dentários da Faculdade de Odontologia da Universidade de São Paulo. Os animais foram mantidos em gaiolas com maravalha de pinus e com acesso à água e ração ad libitum e com condições controladas de iluminação (12hs luz/12hs de escuro), temperatura $23^{\circ} \pm 2^{\circ} \mathrm{C}$ e umidade $55 \pm 10 \%$ no Biotério do Departamento de Materiais Dentários da Faculdade de Odontologia da Universidade de São Paulo. Este trabalho foi aprovado pelo Comitê de Ética em Pesquisa da Faculdade de Odontologia da Universidade de São Paulo, FOUSP (Anexo A).

\subsection{2 instrumentos}

Punch cirúrgico descartável estéril de $6 \mathrm{~mm}$ de diâmetro (Kolplast). 
Corante Azul de Metileno a (0,01\%) Quimiolux (Hypofarma - Ribeirão das Neves - MG).

Power-meter - Power Max 600 (Molectron - EUA).

Laser diodo de baixa potência (InGaAIP), comprimento de onda vermelho (660nm). Photon Lase III (DMC equipamentos, São Carlos - SP).

Máquina fotográfica (Canon EOS 350D Digital Rebel XT SLR)

\subsection{Métodos}

\subsection{1 método experimental}

Todos os animais foram pesados e anestesiados previamente à cirurgia com $50 \mathrm{mg} / \mathrm{kg}$ de Pentobarbital e $50 \mathrm{mg} / \mathrm{kg}$ de Ketamina. As excisões cirúrgicas foram precedidas por tricotomia (pele) e, no dorso de cada animal foi realizada uma excisão circular de $6 \mathrm{~mm}$ de diâmetro com punch. Todo o procedimento cirúrgico foi realizado por um único operador, tomando-se o cuidado de manter a mesma profundidade da ferida para todos os animais.

Os animais foram aleatoriamente divididos em 4 (quatro) grupos experimentais, cada um contendo 25 (vinte e cinco) animais: 1- Grupo Controle; 2Grupo Corante; 3- Grupo Laser; 4- Grupo PDT. O tratamento de cada grupo está relacionado a seguir:

Grupo Controle: apenas excisão cirúrgica; 
Grupo Corante: aplicação tópica do corante de azul de metileno por sobre a ferida durante 5 minutos. Após a aplicação segue-se a retirada do corante com gaze úmida.

Grupo Laser: Irradiação com laser $\left(120 \mathrm{~J} / \mathrm{cm}^{2} ; 100 \mathrm{~mW} ; 33 \mathrm{~s}\right)$ em um único ponto localizado no centro da ferida.

Grupo PDT: Aplicação tópica de corante azul de metileno por 5 minutos por sobre a excisão realizada, seguida de irradiação laser (conforme descrita acima) (Figura 4.1).

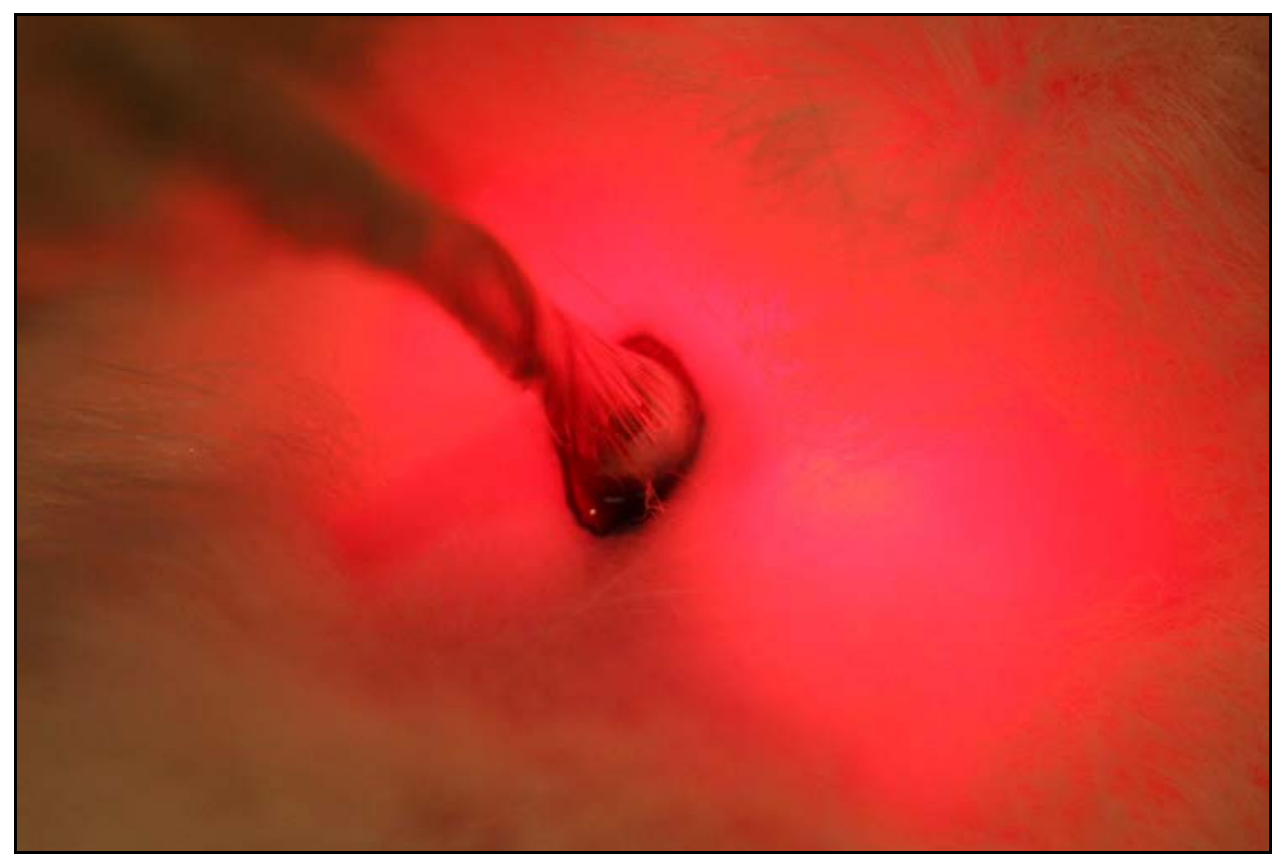

Figura 4.1 - Animal pertencente ao grupo PDT recebendo irradiação laser após aplicação tópica do corante azul de metileno por sobre a excisão

Após as intervenções realizadas, os animais foram novamente divididos em 5 (cinco) grupos $(n=20)$, conforme o tempo de sacrifício: Um dia após a cirurgia (T1), 3 dias (T2), 5 dias (T3), 7 dias (T4) e 14 dias após a cirurgia (T5). O método adotado para o sacrifício dos animais foi o de dose letal de anestésico. 


\subsection{2 análise clínica}

O processo clínico de reparação tecidual foi fotografado e posteriormente analisado.

Para a realização das fotografias, foi utilizada a máquina fotográfica acoplada a um tripé próprio, mantendo-se a distância focal de $17 \mathrm{~cm}$ com o dorso do animal fotografado. As fotos foram realizadas nos seguintes tempos: Imediatamente após o procedimento cirúrgico, 1 dia, 2 dias, 3 dias, 5 dias, 7 dias, 10 dias e 14 dias após o procedimento cirúrgico.

Após a realização de todas as fotos, estas foram analisadas pelo programa ImageLab 2000 no Laboratório de Informática Dedicado á Odontologia. Foram calculados os valores de fator de forma (área da ferida sobre a maior distância medida entre suas bordas elevada ao quadrado), perímetro da lesão e área da lesão (Figura 4.2). As feridas foram delimitadas por uma única pessoa de forma cega. Ou seja, sem que esta soubesse à qual grupo pertencia cada figura. O cálculo das dimensões citadas acima foi efetuado automaticamente pelo computador, e os valores foram anotados em tabelas no programa Microsoft Excel para posterior análise estatística. 


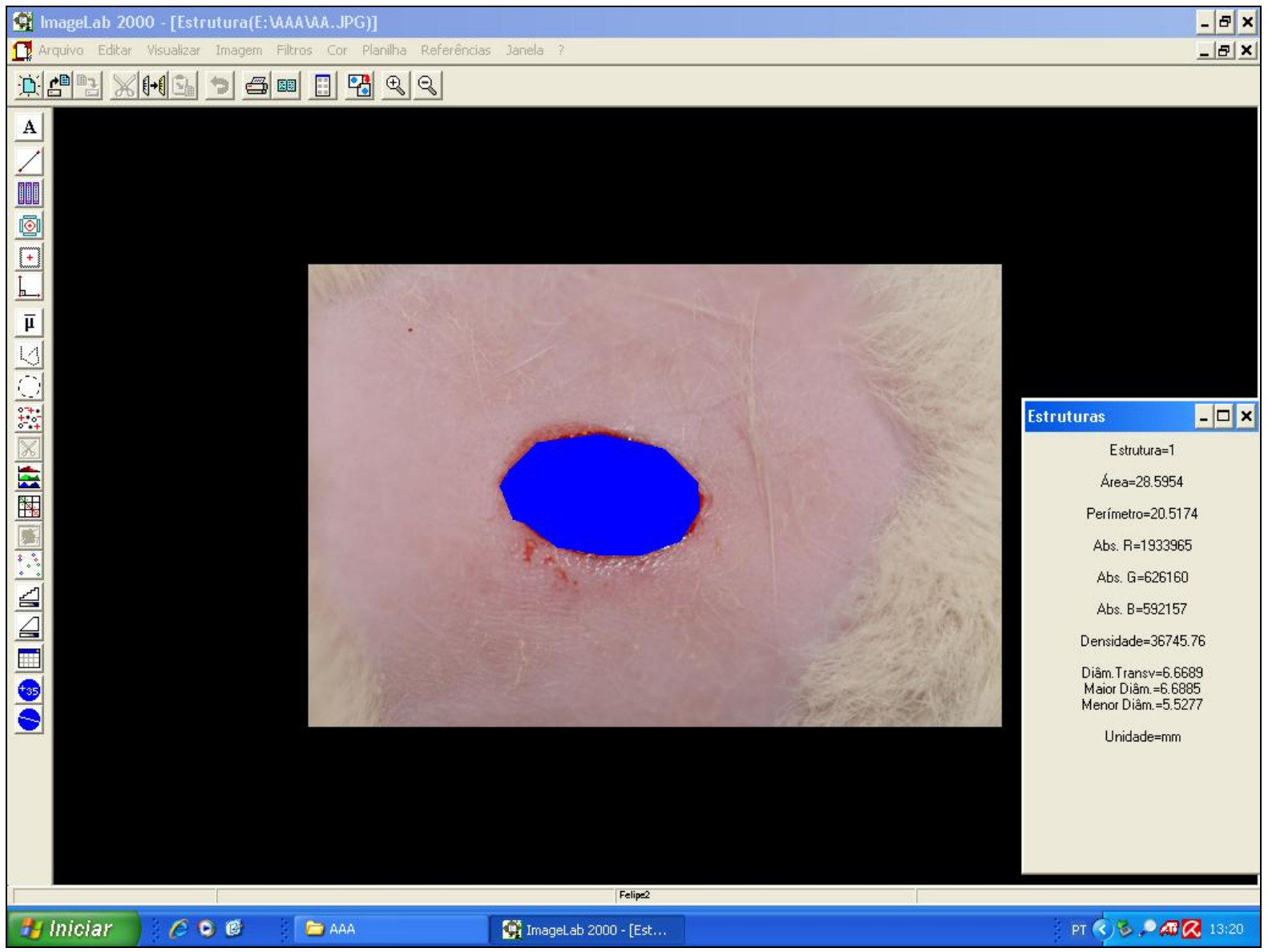

Figura 4.2 - Imagem retirada do programa ImageLab 2000. A área da ferida em questão encontra-se delimitada e pintada de azul. Os valores de área, perímetro e fator de forma podem ser visualizados ao lado direito da imagem

\subsection{3 análise estatística}

Os dados obtidos com a análise das fotos clínicas (fator de forma, área e perímetro das feridas) foram enviados à análise estatística. Os testes utilizados foram os de Kruskal-Wallis e Mann-Whitney, adotando-se o nível de significância de $5 \%(0,050)$ 


\subsection{4 preparo para histologia}

Após o sacrifício, de acordo com os tempos de 1 dia, 3 dias, 5 dias, 7 dias e 14 dias após a cirurgia, as áreas excisionadas foram cirurgicamente removidas, fixadas em formol a $10 \%$ e, em seguida enviadas ao laboratório de Patologia Bucal da FOUSP, onde foram processadas rotineiramente para inclusão em blocos de parafina.

\subsection{5 análise histo-morfológica}

Cortes de $5 \mu \mathrm{m}$ de cada amostra foram obtidos e corados pela técnica da hematoxilina e eosina (H.E.) para análise histo-morfológica. Todas as etapas laboratoriais foram realizadas no Laboratório de Patologia Bucal da Faculdade de Odontologia da USP-SP.

As lâminas obtidas de cada grupo e tempo experimental foram analisadas em microscópio de luz por três examinadores pré-calibrados. Foi realizada análise descritiva de cada corte, além de serem avaliados pela seguinte escala semiquantitativa de intensidade: 0 a $3(0=$ ausência; $1=$ presença fraca; $2=$ presença moderada; 3= presença intensa). Nesta análise foi observada a intensidade dos seguintes aspectos: Edema, necrose, infiltrado inflamatório, tecido de granulação, presença de fibroblastos jovens. 
A presença de re-epitelização também foi avaliada em uma escala de 0 a 4 $(0=$ ausência; $1=$ início de re-epitelização; 2= re-epitelização moderada; $3=$ reepitelização quase completa; 4= epitélio íntegro).

Foi realizada a média aritmética simples dos dados obtidos para cada grupo em cada tempo experimental, e estes foram organizados em tabelas.

\subsection{6 imunoistoquímica}

As reações de imunoistoquímica foram feitas pelo método da streptavidinabiotina peroxidase. Foram utilizados cortes de $3 \mu \mathrm{m}$ de espessura a partir do material previamente fixado em formol a $10 \%$ e emblocado em parafina. Os cortes foram estendidos em lâminas de vidro previamente lavadas em álcool absoluto, secas e mergulhadas por um minuto em solução de 3-aminopropitrietoxi-silano (Sigma Chemical CO, St Louis, MO/USA) a 10\% em álcool absoluto (lâminas silanizadas).

A seguir, os cortes foram desparafinados em dois banhos de xilol absoluto a $60^{\circ} \mathrm{C}$, por trinta minutos e à temperatura ambiente por vinte minutos respectivamente. Em seguida, foram re-hidratados em séries decrescentes de etanóis $(100 \%, 95 \%$ e $85 \%$, respectivamente). Para remover os pigmentos formólicos, os cortes ficaram imersos em hidróxido de amônia a 10\%, em solução alcoólica a 95\%, durante 10 minutos. Após lavagem em água corrente e dois banhos de água destilada, as lâminas receberam os tratamentos para recuperação antigênica, que consistiu em banho-maria a $95^{\circ} \mathrm{C}$ com ácido cítrico pH 6,0. 
Seguiu-se o bloqueio da peroxidase endógena tecidual que foi feito com dois banhos de cinco minutos cada um em solução de peróxido de hidrogênio a $6 \%$ e metanol $(1: 1 \mathrm{v} / \mathrm{v})$. Posteriormente foram realizadas lavagem em água corrente por 10 minutos, 2 banhos de água destilada e 2 banhos de 5 minutos cada em tampão TRIS-HCL (hidroximetil-amino-metano) 0,5M e pH7,4. As lâminas foram colocadas no equipamento Dako Autostainer Universal Staining System (Dako Corp., Carpenteria CA, USA) onde foram realizadas as etapas de incubação dos anticorpos primários (p63 - Mouse/Anti-human, Clone 4A4, Dako, Dinamarca; Citoqueratina 10 - Mouse/Anti-human, Clone DE K10, Dako-Dinamarca, Citoqueratina 14 - Mouse, NeoMarkers, Fremont CA, USA) por quarenta minutos cada e incubação do complexo estreptoavidina-biotina (kit LSAB Peroxidase K0609 - Dako Corp. CA, USA) por 30 minutos.

Para a reação de revelação foi usado o cromógeno diaminobenzidina 0,025\% (DAB, 3,3-diaminobenzidina, Sigma Chemical Co., St Louis MO/USA) por dez minutos. Após a lavagem, os cortes foram contra-corados com a hematoxilina de Mayer previamente filtrada por cinco minutos.

Os passos seguintes, feitos manualmente foram a desidratação em uma cadeia ascendente de etanol seguindo a seqüência de $70 \%, 90 \%$ e 100\% durante 2 minutos cada banho e diafanização em xilol (2 banhos de 5 minutos cada). As lâminas de vidro foram então montadas com lamínulas de vidro e com Permount (Fischer Scientific, Fair Lawn, NJ, USA).

Para cada tipo de anticorpo foi utilizado um controle positivo (tecido sabidamente positivo) e um controle negativo. O controle negativo foi realizado através da abolição do anticorpo primário. Foram utilizados como controle positivo tecidos humanos e de rato. 
4.2.7 análise dos resultados

\subsubsection{1 p63}

A imuno-expressão do p63 foi avaliada por três examinadores pré-calibrados em microscópio de luz com aumento final de 100X. Foi realizada análise descritiva de todos os cortes e análise semi-quantitativa e foi estabelecido um método para analisar a quantidade de células marcadas. O método encontra-se descrito abaixo.

A área da ferida foi dividida em cinco campos numerados da seguinte maneira: 1 e 2: epitélio distante da ferida; 3 e 4: epitélio próximo à ferida e 5: epitélio que recobre a área da excisão (para as excisões já recobertas por epitélio) (Figura 4.3).

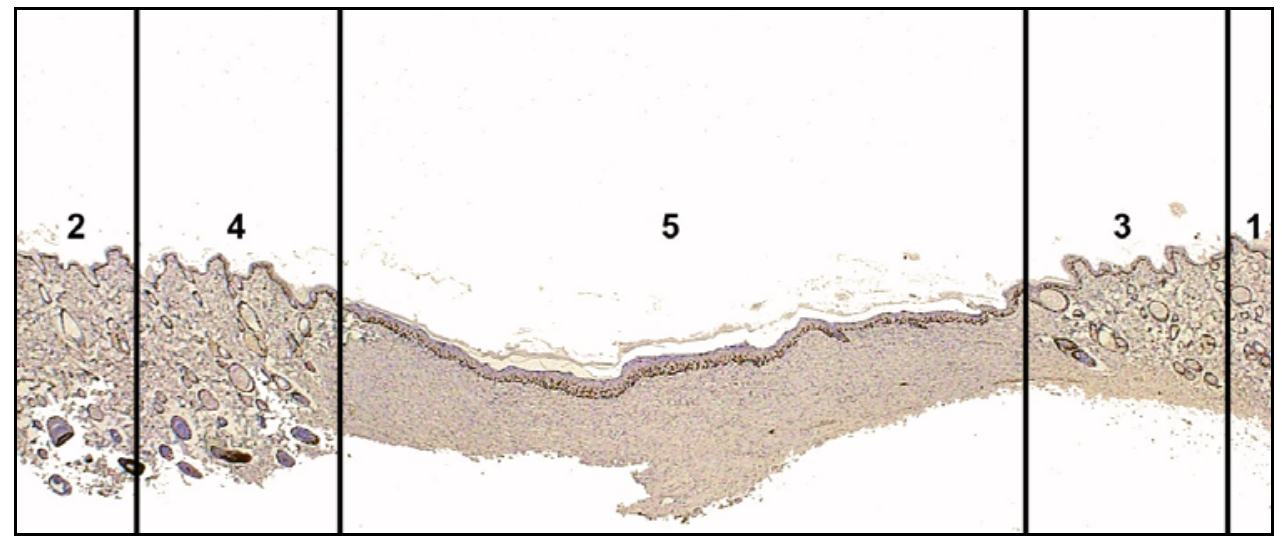

Figura 4.3 - Campos numerados para avaliação da expressão de p63: 1 e 2 - Epitélio distante; 3 e 4 - Epitélio próximo; 5 - Epitélio recém-formado 
Os campos foram classificados em uma escala de intensidade de marcação de 0 a 4 (WALKER RA, 2006), sendo:

- 0 - Ausência completa da expressão de p63;

- 0,1 a 1 - 1 a 25\% de células expressando p63;

- 1,1 a 2 - 26 a 50\% de células expressando p63;

- 2,1 a 3 - 51 a $75 \%$ de células expressando p63;

- $\quad 3,1$ a 4 - 76 a $100 \%$ de células expressando p63.

Posteriormente, foi realizada a média aritmética simples dos valores obtidos para cada grupo estudado em cada tempo experimental.

\subsubsection{Citoqueratinas 10 e 14}

Foram avaliadas suas expressões por três examinadores précalibrados em microscópio óptico. Foi realizada análise descritiva de todos os cortes e também análise semi-quantitativa em uma escala de 0 a 3 (0=ausência de marcação; 1= marcação fraca; 2= marcação moderada; 3= marcação intensa) para as seguintes áreas do corte: Camadas basal, intermediária e supra-basal do epitélio íntegro e; camadas basal, intermediária e supra-basal do epitélio migrado. 


\section{RESULTADOS}

\subsection{Análise clínica da reparação tecidual}

\section{- tempo inicial}

As excisões se extendiam, em profundidade, até a fáscia muscular, apresentando bordas definidas e sangrantes para todos os grupos estudados. Para os grupos Corante e PDT observava-se a presença residual do corante azul de metileno em meio ao exsudato próprio das feridas (Figuras 5.1 A,B,C,D).

\section{- 24 horas após procedimento cirúrgico}

As excisões pertencentes a todos os grupos estudados apresentavam formação de crosta e tendência ao formato circular. Nenhuma das feridas apresentava sangramento e em três das feridas do grupo corante ainda era possível observar pequena presença residual do corante azul de metileno. Esta presença era localizada na borda das feridas. 
- 48 horas após procedimento cirúrgico

As excisões apresentavam-se semelhantes às analisadas no tempo anterior, com seu formato tendendo ao circular. Em geral, as crostas recobrindo as feridas dos grupos Laser e PDT apresentavam-se mais escuras e espessas.

\section{- 72 horas após o procedimento cirúrgico}

O formato de todas as excisões analisadas tendia ao circular. Todas as excisões apresentavam-se recobertas por crostas, sendo que as crostas das excisões pertencentes aos grupos Laser e PDT eram aparentemente mais escuras e mais espessas.

\section{- 5 dias após o procedimento cirúrgico}

Semelhantemente ao tempo de 72 horas, todas as excisões apresentavam-se recobertas por crostas, sendo estas mais escuras e aparentemente mais espessas para os grupos Laser e PDT. O formato das excisões apresentava-se irregular e tendendo para o circular.

\section{- 7 dias após o procedimento cirúrgico}

Todas as excisões analisadas ainda apresentavam-se recobertas por crostas, em geral mais escuras e aparentemente mais espessas para os grupos Laser e PDT (Figuras 5.1 E, F, G, H). 
- 10 dias após o procedimento cirúrgico

As excisões dos grupos Controle e Corante já não apresentavam crostas, sendo que estas haviam sido substituídas por um tecido cicatricial, e seus formatos tendiam ao elíptico. O formato das excisões do grupo Laser e PDT tendia ao circular. Duas das feridas do grupo Laser e uma do grupo PDT apresentavam crostas mínimas.

- 14 dias após o procedimento cirúrgico

O local previamente excisionado apresentava-se marcado por uma área mínima de tecido cicatricial, sendo este de forma elíptica. A área que havia sofrido tricotomia apresentava-se já recoberta por pêlos (Figuras $5.1 \mathrm{I}, \mathrm{J}, \mathrm{K}, \mathrm{L}$ ). 


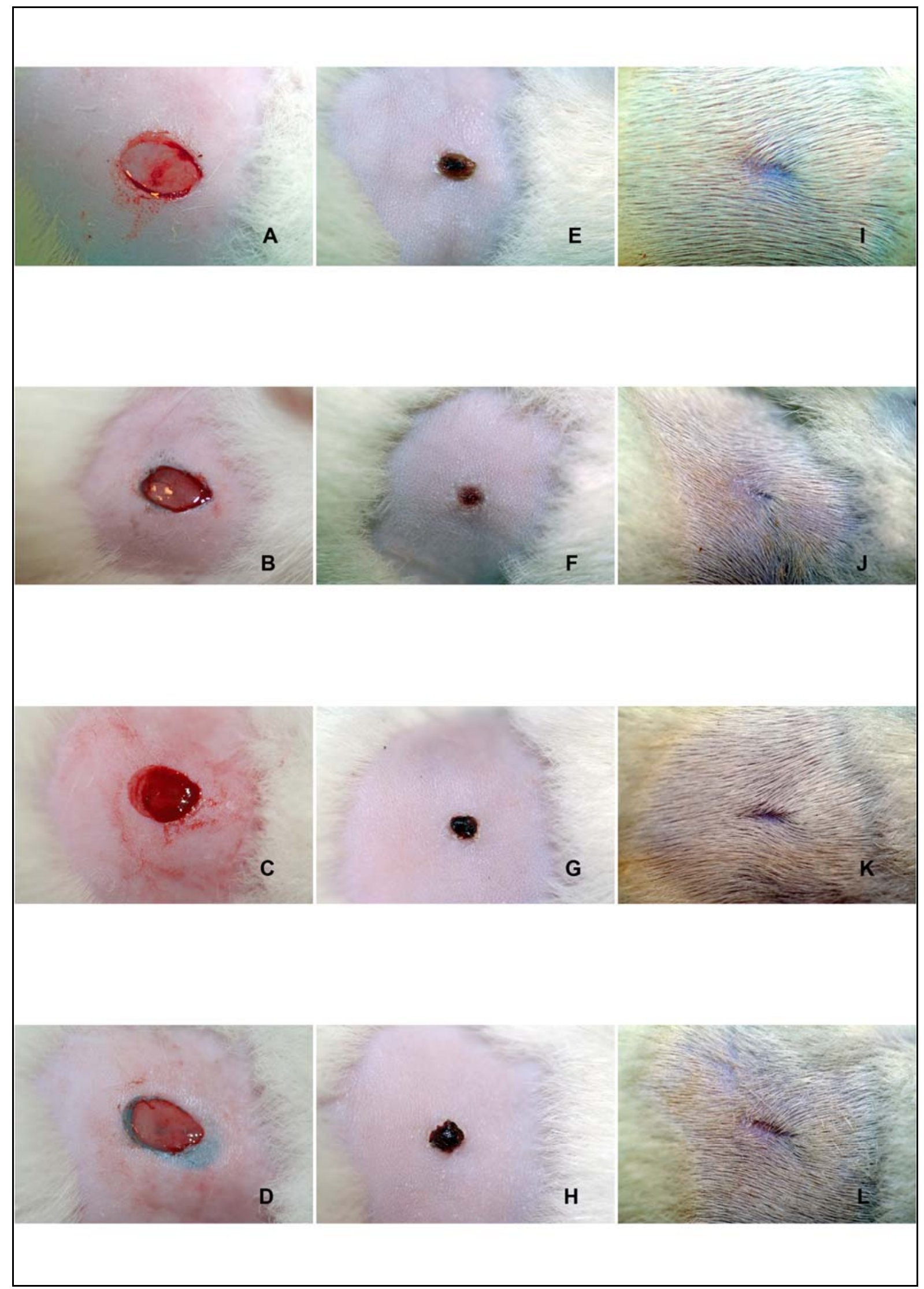

Figura 5.1 
Figura 5.1 - A - Controle (tempo inicial). Nota-se ferida bem delimitada com presença de exsudato próprio; B - Corante (tempo inicial). Pode ser notada a presença remanescente do corante azul de metileno em meio ao exsudato; C - Laser (tempo inicial). Nota-se maior coagulação sanguínea se comparado aos outros grupos; D - PDT (tempo inicial). Ainda pode ser notada a presença remanescente do corante azul de metileno na ferida; E Controle (7 dias). Ferida com formato circular recoberta por crosta; $\mathrm{F}$ - Corante (7 dias). Ferida circular recoberta por crosta; G - Laser (7 dias). Ferida recoberta por crosta espessa e mais escura do que aquela presente nos grupos Controle e Corante; $\mathrm{H}$ - PDT (7 dias). Ferida recoberta por costa semelhante àquela vista no grupo Laser; I - Controle (14 dias). Área da ferida recoberta por tecido cicatricial com forma elíptica e maior do que aquela observada nos outros grupos. Já pode ser notada presença de pêlos; $\mathrm{J}$ - Corante (14 dias). Área da ferida recoberta por tecido cicatricial de forma elíptica e presença de pêlos; $\mathrm{K}$ - Laser (14 dias). Tecido cicatricial de forma elíptica e área menor do que aquela observada no grupo Controle, além da presença de pêlos; L - PDT (14 dias). Tecido cicatricial de forma elíptica e presença de pêlos ao redor da área da lesão

\subsection{Análise estatística}

As médias dos valores obtidos de área, perímetro e fator de forma para cada grupo analisado foram organizadas em gráficos, de acordo com cada tempo experimental (Gráficos 5.1, 5.2 e 5.3).

Com o intuito de verificar se houve possíveis diferenças entre os quatro grupos analisados (Controle, Corante, Laser e PDT), quando comparados concomitantemente, para as variáveis de interesse fator de forma, perímetro e área da lesão, foi realizado o teste de Kuskal-Wallis $(p<0,050)$ (Anexo B). 


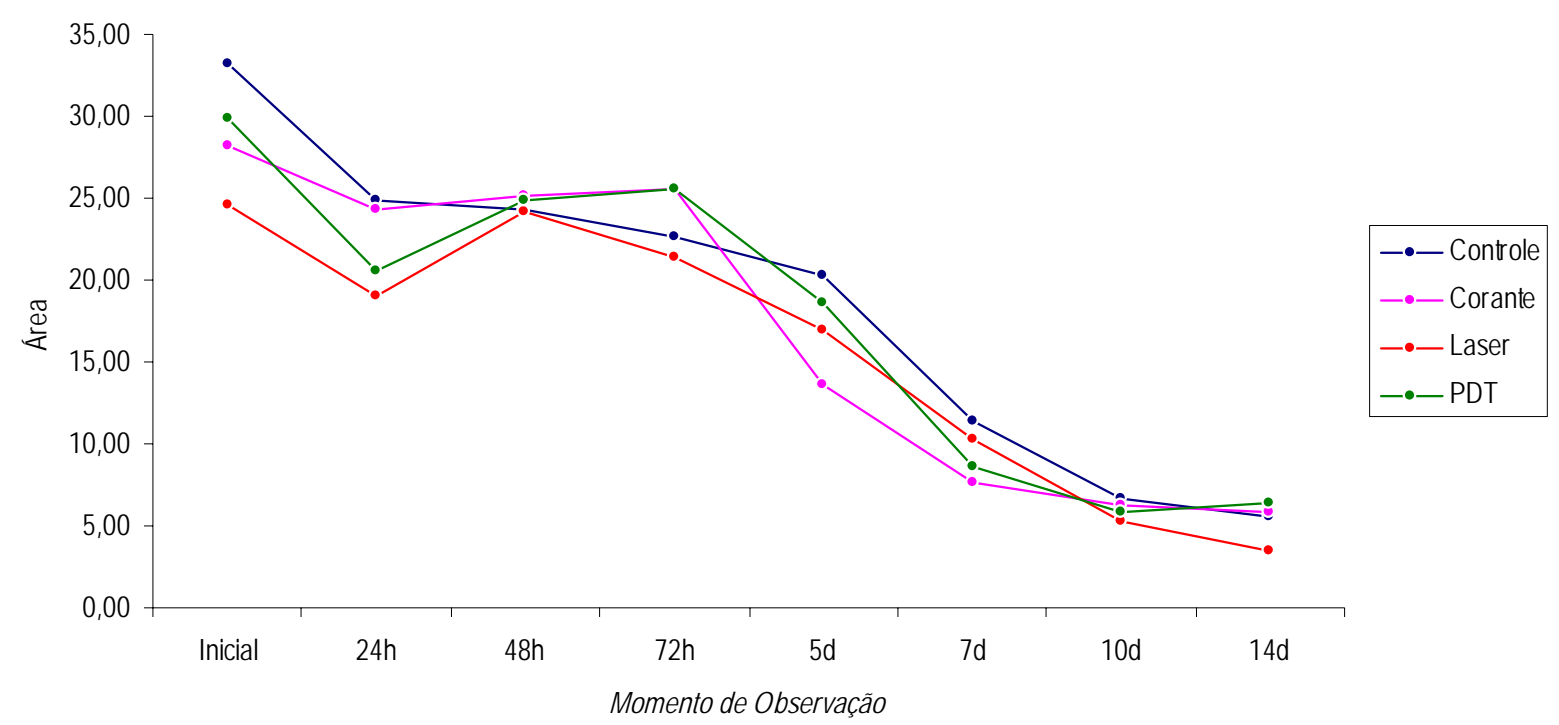

Gráfico 5.1 - Média dos valores de área $\left(\mathrm{mm}^{2}\right)$ para cada grupo segundo os períodos experimentais

De acordo com o gráfico 5.1, pode-se observar que a área média do grupo Laser, com exceção para os períodos de cinco e sete dias, manteve-se sempre menor do que a dos outros grupos estudados, sendo esta diferença estatisticamente significante aos quatorze dias de pós-operatório (Vide anexo B). 


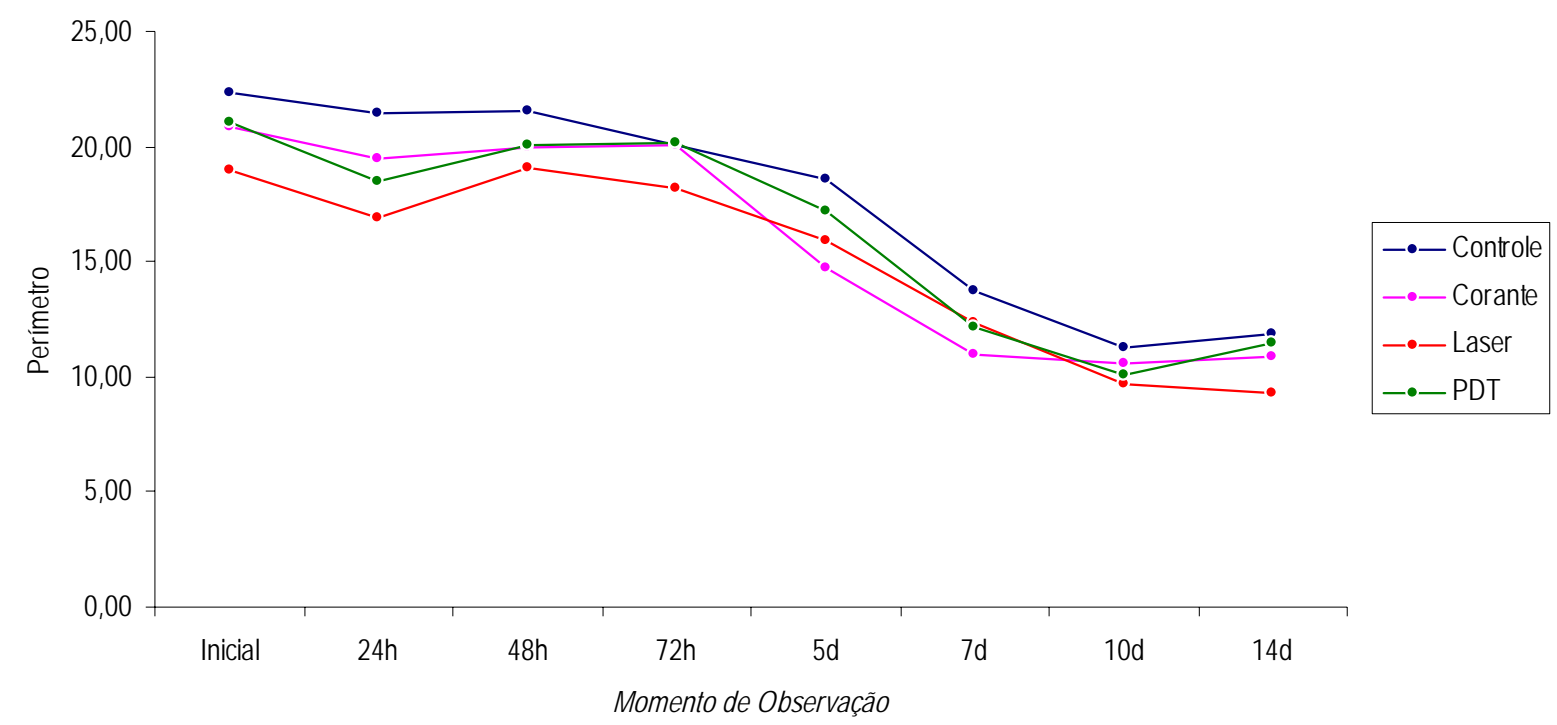

Gráfico 5.2 - Média dos valores de perímetro $(\mathrm{mm})$ para cada grupo segundo os períodos experimentais

Segundo o gráfico 5.2, o perímetro médio observado no grupo Laser manteve-se menor do que o dos outros grupos, com exceção para os períodos de cinco e sete dias. Não foram observadas diferenças estatisticamente significantes para a variável perímetro. 


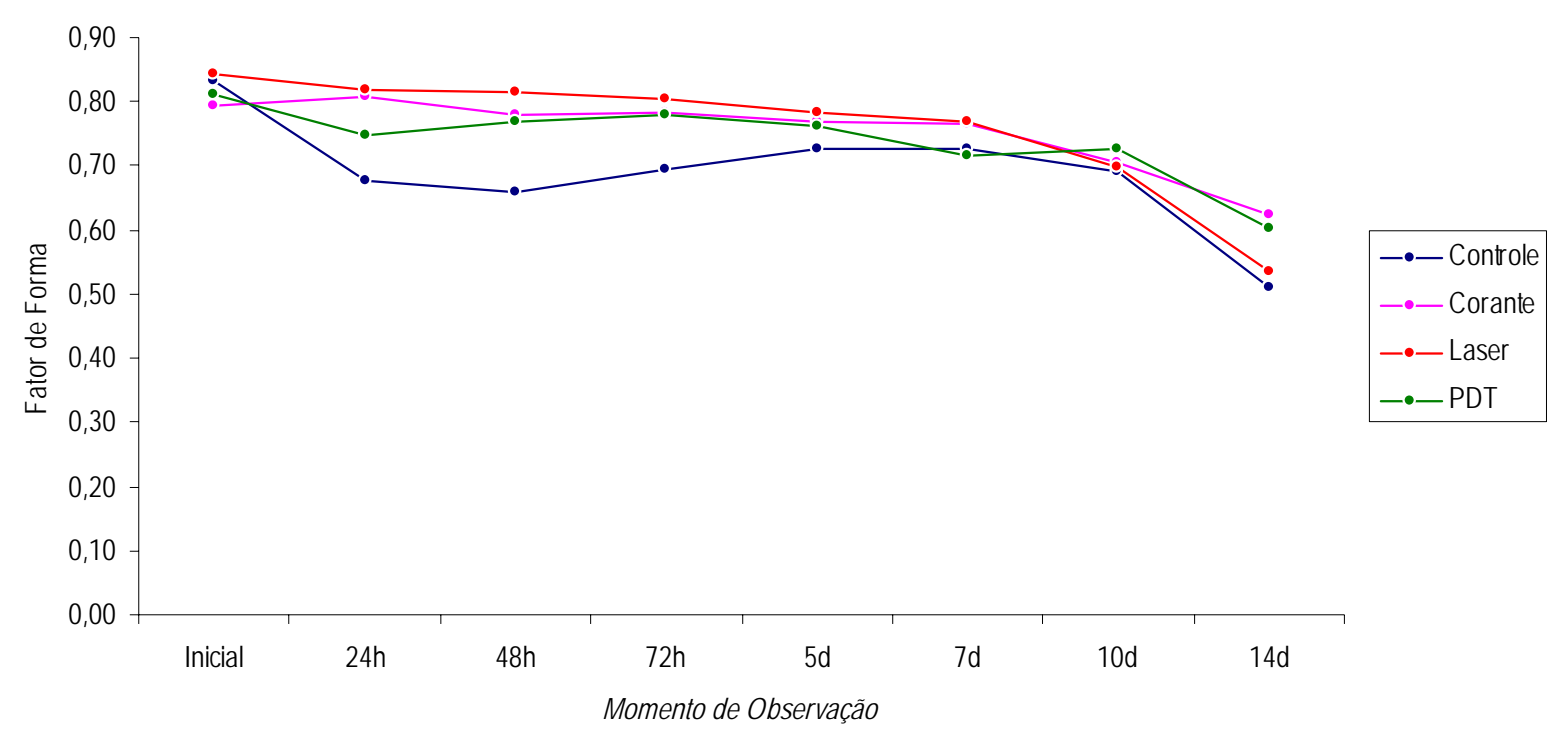

Gráfico 5.3 - Média dos valores obtidos de fator de forma para cada grupo segundo os períodos experimentais

O gráfico 5.3 mostra a relação dos valores médios de fator de forma obtidos para cada grupo de acordo com os períodos experimentais estudados. Os valores iniciais obtidos encontravam-se muito próximos entre si, porém mostraram diferenças estatisticamente significantes para os tempos de 24 e 48 horas (vide anexo B), e voltaram a se aproximar aos cinco dias, não havendo mais diferenças estatisticamente significantes entre eles.

Portanto, foram notadas diferenças estatisticamente significantes para a variável de fator de forma entre os grupos analisados no período de 24 horas e 48 horas. Os grupos também apresentaram diferenças estatisticamente significantes para a variável área no período de 14 dias.

Assim, para estas três variáveis (fator de forma 24 horas, fator de forma 48 horas e área 14 dias) realizou-se o teste de Mann-Whitney para verificar quais grupos diferiram dos demais, quando comparados par a par (Tabela 5.1). 
Tabela 5.1 - Teste de Mann-Whitney. As diferenças estatisticamente significantes estão representadas em vermelho

\begin{tabular}{c|cccccc}
\hline \multirow{2}{*}{ Variável } & \multicolumn{7}{|c}{ Par de Grupos } \\
& $\begin{array}{c}\text { Controle } \mathrm{x} \\
\text { Corante }\end{array}$ & $\begin{array}{c}\text { Controle } \mathrm{x} \\
\text { Laser }\end{array}$ & $\begin{array}{c}\text { Controle } \mathrm{x} \\
\text { PDT }\end{array}$ & $\begin{array}{c}\text { Corante } \mathrm{x} \\
\text { Laser }\end{array}$ & $\begin{array}{c}\text { Corante X } \\
\text { PDT }\end{array}$ & $\begin{array}{c}\text { Laser } \mathrm{x} \\
\text { PDT }\end{array}$ \\
\hline F_Forma_24h & 0,021 & 0,016 & 0,293 & 0,598 & 0,012 & 0,011 \\
F_Forma_48h & 0,021 & 0,009 & 0,047 & 0,169 & 0,834 & 0,207 \\
Área_14d & 0,465 & 0,009 & 0,347 & 0,009 & 0,347 & 0,016 \\
\hline
\end{tabular}

Por meio do teste de Mann-Whitney, quando analisada a variável fator de forma no período de 24 horas, foram encontradas diferenças estatisticamente significantes entre os grupos Controle e Corante, Controle e Laser, Corante e PDT e Laser e PDT, sendo o fator de forma dos grupos Controle e PDT menores do que aqueles encontrados para os grupos Corante e Laser (vide anexo B). Quando analisada a variável fator de forma no período de 48 horas, foram encontradas diferenças estatisticamente significantes entre os grupos Controle e Corante, Controle e Laser e Controle e PDT, sendo o valor do fator de forma menor para o grupo Controle (vide anexo B). Por fim, quando analisada a variável área no período de 14 dias após a realização da intervenção cirúrgica, foram encontradas diferenças entre os grupos Controle e Laser, Corante e Laser e Laser e PDT, sendo a área do grupo Laser menor do que aquela encontrada nos outros grupos (vide anexo B). 


\subsection{Análise morfológica (HE)}

\section{- 24 horas após o procedimento cirúrgico}

Todos os cortes caracterizavam-se por fragmentos de pele revestidos por epitélio pavimentoso estratificado queratinizado com ampla discontinuidade epitelial localizada, superfície necrótica e intenso infiltrado inflamatório predominantemente neutrofílico (Figura 5.2A). Na derme era possível observar-se infiltrado mono e polimorfonuclear com áreas focais de hemorragia, vasos hiperêmicos e edema intersticial estendendo-se para o subcutâneo. Os cortes pertencentes aos grupos Corante e PDT apresentavam maior número de macrófagos se comparados ao grupo Controle. Os grupos Laser e PDT apresentavam início da formação da língua epitelial, maior número de fibroblastos jovens e menor formação de tecido de granulação, além de maior quantidade de fibrina quando comparados aos outros grupos (Figura 5.2B).

\section{- 72 horas após o procedimento cirúrgico}

Todos os cortes apresentavam discontinuidade epitelial localizada com presença de tecido de granulação, necrose e edema intersticial. $O$ infiltrado inflamatório era predominantemente mononuclear. Podia ser observado início de reepitelização, com formação de língua epitelial. Esta re-epitelização encontrava-se maior para os grupos Laser e PDT (Figura 5.2C). Além disso, para estes grupos a 
formação de tecido de granulação era maior, porém o infiltrado inflamatório encontrava-se visualmente menor.

\section{- 5 dias após o procedimento cirúrgico}

Neste tempo de observação, os grupos estudados apresentavam todos os elementos descritos no tempo anterior, como necrose, edema e presença de infiltrado inflamatório. O infiltrado inflamatório era predominantemente mononuclear, e semelhante para os quatro grupos. A formação de epitélio já se encontrava aumentada (Figura 5.2D); sendo maior para o grupo Laser, seguida pelo grupo PDT. De fato, dois dos animais analisados pertencentes ao grupo Laser apresentavam completa formação de epitélio (Figura 5.2E). A presença de tecido necrótico e edema intersticial era visualmente menor para os grupos Laser e PDT.

\section{- 7 dias após o procedimento cirúrgico}

Os cortes pertencentes ao grupo Laser já mostravam formação completa de epitélio, sem presença de infiltrado inflamatório ou necrose. Já havia formação de queratina e estratificação em camadas, além de mais fibras colágenas (Figura 5.2F). O tecido de granulação para este grupo também se apresentava menor. Os outros três grupos mostravam re-epitelização avançada, porém ainda incompleta (Figura 5.2G). O infiltrado inflamatório era predominantemente mononuclear, com ainda presença de necrose e tecido de granulação. Para o grupo Controle, não mais se observava edema. 


\section{- 14 dias após o procedimento cirúrgico}

Todos os cortes apresentavam epitélio completamente formado por sobre a úlcera pré-existente (Figura $5.2 \mathrm{H}$ ). Notava-se ainda tecido de granulação para os cortes pertencentes aos grupos Controle e Corante e maior presença de fibroblastos jovens para estes, se comparados aos grupos Laser e PDT. Nos grupos Laser e PDT, a colagenização já estava completa e em remodelação.

A análise semi-quantitativa das lâminas coradas em HE está relacionada nas tabelas 5.2 a 5.6 de acordo com os tempos de sacrifício.

Tabela 5.2 - Análise semi-quantitativa do tempo de 24 horas (HE)

\begin{tabular}{ccccccc}
\hline 24 horas & Edema & Necrose & $\begin{array}{c}\text { Infiltrado } \\
\text { Inflamatório }\end{array}$ & $\begin{array}{c}\text { Tecido de } \\
\text { Granulação }\end{array}$ & $\begin{array}{c}\text { Re- } \\
\text { epitelização }\end{array}$ & $\begin{array}{c}\text { Fibroblastos } \\
\text { Jovens }\end{array}$ \\
\hline Controle & 2,75 & 2 & 2,5 & 0,5 & 0 & 1 \\
\hline Corante & 3 & 1,75 & 2,25 & 0,75 & 0 & 1 \\
\hline Laser & 3 & 3 & 3 & 0 & 1 & 2 \\
\hline PDT & 3 & 2,5 & 2,5 & 0 & 0,25 & 1,5 \\
\hline
\end{tabular}

Tabela 5.3 - Análise semi-quantitativa do tempo de 72 horas (HE)

\begin{tabular}{ccccccc}
\hline 72 horas & Edema & Necrose & $\begin{array}{c}\text { Infiltrado } \\
\text { Inflamatório }\end{array}$ & $\begin{array}{c}\text { Tecido de } \\
\text { Granulação }\end{array}$ & $\begin{array}{c}\text { Re- } \\
\text { epitelização }\end{array}$ & $\begin{array}{c}\text { Fibroblastos } \\
\text { Jovens }\end{array}$ \\
\hline Controle & 2 & 3 & 2 & 1 & 1 & 2 \\
\hline Corante & 1 & 1,67 & 2 & 1 & 1 & 2 \\
\hline Laser & 1,67 & 1,34 & 1 & 1,67 & 2 & 2 \\
\hline PDT & 2 & 2 & 1 & 2 & 2 & 2 \\
\hline
\end{tabular}


Tabela 5.4 - Análise semi-quantitativa do tempo de 5 dias (HE)

\begin{tabular}{ccccccc}
\hline 5 dias & Edema & Necrose & $\begin{array}{c}\text { Infiltrado } \\
\text { Inflamatório }\end{array}$ & $\begin{array}{c}\text { Tecido de } \\
\text { Granulação }\end{array}$ & $\begin{array}{c}\text { Re- } \\
\text { epitelização }\end{array}$ & $\begin{array}{c}\text { Fibroblastos } \\
\text { Jovens }\end{array}$ \\
\hline Controle & 0,7 & 1,34 & 1 & 2,34 & 2,34 & 3 \\
\hline Corante & 1 & 1 & 1 & 2,67 & 2,67 & 3 \\
\hline Laser & 0,34 & 0,34 & 1 & 3 & 3,67 & 3 \\
\hline PDT & 0,67 & 1 & 1 & 2 & 3 & 3 \\
\hline
\end{tabular}

Tabela 5.5 - Análise semi-quantitativa do tempo de 7 dias (HE)

\begin{tabular}{ccccccc}
\hline 7 dias & Edema & Necrose & $\begin{array}{c}\text { Infiltrado } \\
\text { Inflamatório }\end{array}$ & $\begin{array}{c}\text { Tecido de } \\
\text { Granulação }\end{array}$ & $\begin{array}{c}\text { Re- } \\
\text { epitelização }\end{array}$ & $\begin{array}{c}\text { Fibroblastos } \\
\text { Jovens }\end{array}$ \\
\hline Controle & 0 & 0,5 & 1 & 3 & 3,75 & 3 \\
\hline Corante & 0,25 & 0,5 & 1 & 3 & 3,75 & 3 \\
\hline Laser & 0,25 & 0 & 0 & 2 & 4 & 3 \\
\hline PDT & 0,67 & 0,67 & 1,34 & 3 & 3,67 & 3 \\
\hline
\end{tabular}

Tabela 5.6 - Análise semi-quantitativa do tempo de 14 dias (HE)

\begin{tabular}{ccccccc}
\hline 14 dias & Edema & Necrose & $\begin{array}{c}\text { Infiltrado } \\
\text { Inflamatório }\end{array}$ & $\begin{array}{c}\text { Tecido de } \\
\text { Granulação }\end{array}$ & $\begin{array}{c}\text { Re- } \\
\text { epitelização }\end{array}$ & $\begin{array}{c}\text { Fibroblastos } \\
\text { Jovens }\end{array}$ \\
\hline Controle & 0 & 0 & 0,5 & 2 & 4 & 2,5 \\
\hline Corante & 0 & 0 & 0 & 1 & 4 & 2 \\
\hline Laser & 0 & 0 & 0 & 0 & 4 & 1 \\
\hline PDT & 0 & 0 & 0 & 0 & 4 & 1 \\
\hline
\end{tabular}




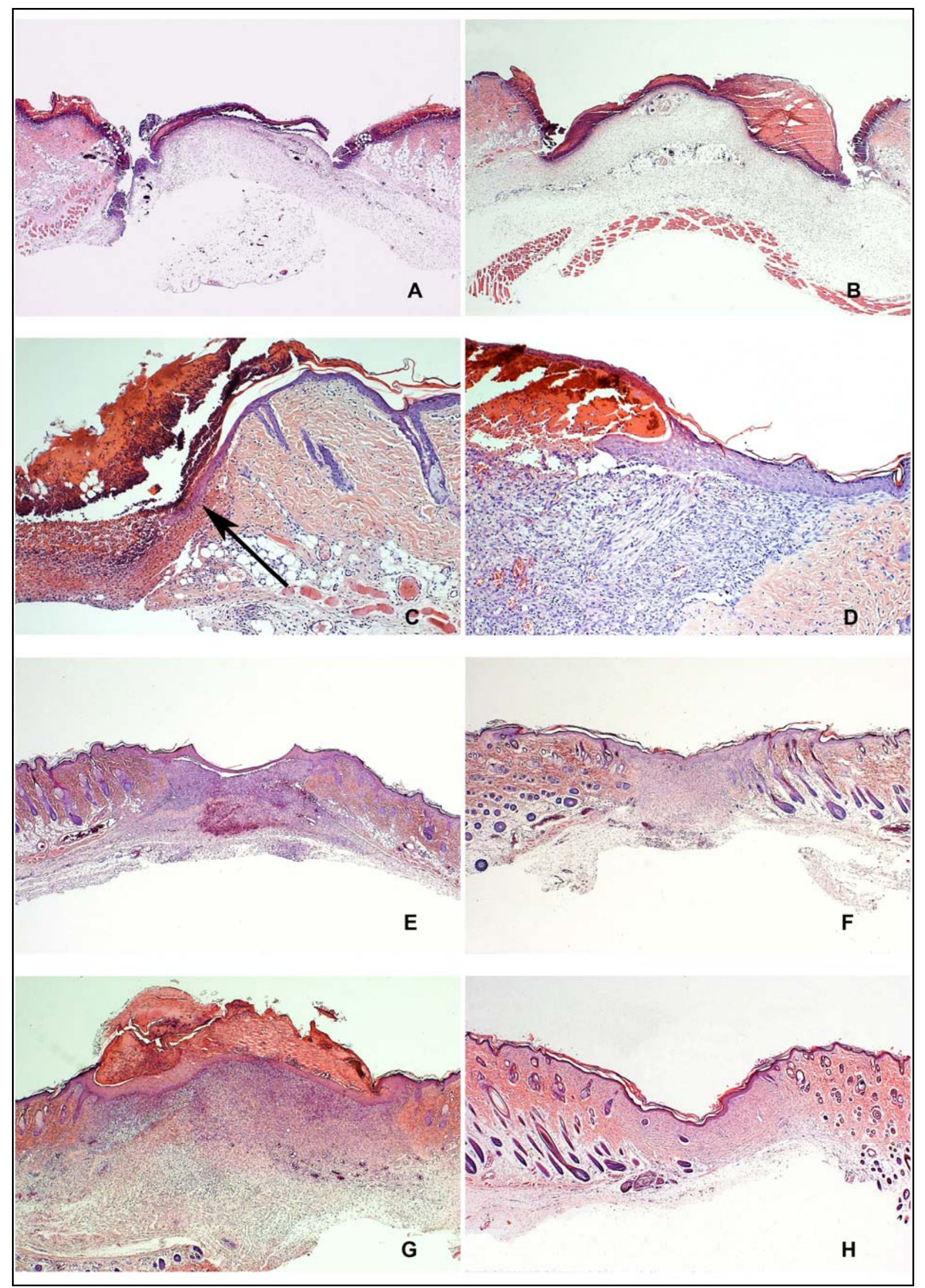

Figura 5.2 
Figura 5.2 - A - Controle 24h. Nota-se ampla discontinuidade epitelial localizada, com superfície necrótica (2,5X HE); $B$ - Laser 24h. Nota-se crosta espessa recobrindo a área da ferida (2,5X HE); C - PDT 72h. Língua epitelial (seta), indicando início de re-epitelização (10X HE); D - Controle 5d. Nota-se re-epitelização avançada, porém não completa (10X HE); E - Laser $5 \mathrm{~d}$. Re-epitelização completa (2,5X HE); F - Laser 7d. Epitélio completamente formado com estratificação em camadas e formação de queratina (2,5X HE); G - PDT $7 d$. Re-epitelização avançada, porém ainda incompleta com presença de crosta proeminente (2,5X HE); $\mathrm{H}$ - Corante 14d. Epitélio completamente formado com presença de queratina e anexos cutâneos $(2,5 \mathrm{X} \mathrm{HE})$

\subsection{Citoqueratina 10}

\section{- 24 horas a realização da cirurgia}

As células das camadas espinhosa e superficial do epitélio íntegro de todos os grupos expressavam citoqueratina 10 , sendo esta marcação de moderada a intensa para os grupos Controle, Corante e Laser, e fraca para o grupo PDT. Além disso, a camada basal do epitélio íntegro não apresentava expressão em nenhum dos grupos analisados. O epitélio migrado não apresentava expressão de citoqueratina 10 em sua camada basal para nenhum dos grupos, além de não apresentar marcação em sua camada espinhosa para os grupos Controle e PDT. Os grupos Corante e Laser apresentavam marcação de fraca a moderada para esta mesma camada. Já para a camada superficial do epitélio migrado, todos os grupos apresentavam marcação de moderada a intensa, com exceção do grupo PDT, que apresentava marcação fraca. Era sempre observado um padrão de marcação intensa em uma das extremidades da injúria e marcação fraca na outra extremidade desta mesma injúria, sendo que a marcação passava a ser intensa à medida que se distanciava da ferida (Figura 5.3A). 


\section{- 72 horas após a realização da cirurgia}

Neste tempo experimental, a expressão de citoqueratina 10 manteve-se de moderada a intensa nas camadas espinhosa e superficial do epitélio íntegro de todos os grupos, tornando-se fraca à medida que se aproximava da ferida (Figura 5.3B). Não foi observada expressão da camada basal do epitélio íntegro ou do epitélio migrado. A expressão de citoqueratina 10 também foi negativa nas camadas espinhosa e superficial do epitélio migrado para os grupos Controle e Corante. O grupo Laser já apresentava expressão fraca na camada espinhosa do epitélio migrado. Porém nos cortes pertencentes ao grupo PDT, era possível observar-se que a expressão de citoqueratina 10 tornava-se nula conforme se avançava em direção à língua epitelial (Figura 5.3C).

\section{- 5 dias após a realização da cirurgia}

A expressão de citoqueratina 10 em todas as camadas do epitélio íntegro apresentava-se semelhante para todos os grupos, sendo de moderada a intensa nas camadas espinhosa e superficial, e nula na camada basal. Havia ausência de expressão da camada basal do epitélio migrado de todos os grupos, porém, a expressão das camadas espinhosa e superficial apresentava diferenças. O grupo PDT apresentava ausência de expressão nestas camadas, sendo que a língua epitelial neste grupo não expressava a proteína (Figura 5.3E). O grupo Laser, no entanto, apresentava expressão fraca para a camada superficial e de fraca a moderada para a camada espinhosa (Figura 5.3D). Os grupos Controle e Corante 
também apresentavam expressão nos mesmos locais, porém a intensidade de marcação era menor do que aquela observada no grupo Laser.

\section{- 7 dias após a realização da cirurgia}

Foi observada expressão semelhante para todos os grupos observados. Esta expressão se localizava nas camadas espinhosa e superficial do epitélio íntegro (moderada a intensa) e nas camadas espinhosa e superficial do epitélio migrado (moderada a intensa) (Figura 5.3F). Não foi observada expressão de citoqueratina 10 para a camada basal do epitélio.

\section{- 14 dias após a realização da cirurgia}

Semelhantemente ao tempo de sete dias, a expressão de citoqueratina 10 pôde ser comprovada nas camadas espinhosa e superficial dos epitélios íntegro e migrado de todos os grupos estudados, sem diferenças significantes de intensidade de marcação entre eles (Figuras $5.3 \mathrm{G}$ e 5.3H). A camada basal do epitélio apresentava ausência de expressão para citoqueratina 10.

A análise semi-quantitativa das lâminas marcadas com citoqueratina 10 está relacionada nas tabelas 5.7 a 5.11 de acordo com os tempos de sacrifício e locais: camadas basal, espinhosa e superficial dos epitélios íntegro e migrado. 
Tabela 5.7 - Análise semi-quantitativa de intensidade de citoqueratina 10 em 24 horas

\begin{tabular}{c|ccc|ccc}
\hline \multirow{2}{*}{ 24 horas } & \multicolumn{3}{|c|}{ Epitélio íntegro } & \multicolumn{3}{c}{ Epitélio migrado } \\
& Basal & Espinhosa & Superficial & Basal & Espinhosa & Superficial \\
\hline Controle & 0 & 2,5 & 3 & 0 & 0 & 3 \\
\hline Corante & 0 & 3 & 3 & 0 & 1,5 & 3 \\
\hline Laser & 0 & 2,5 & 3 & 0 & 1 & 2,5 \\
\hline PDT & 0 & 1 & 1 & 0 & 0 & 1 \\
\hline
\end{tabular}

Tabela 5.8 - Análise semi-quantitativa de intensidade de citoqueratina 10 em 72 horas

\begin{tabular}{c|ccc|ccc}
\hline & \multicolumn{3}{|c|}{ Epitélio íntegro } & \multicolumn{3}{c}{ Epitélio migrado } \\
72 horas & Basal & Espinhosa & Superficial & Basal & Espinhosa & Superficial \\
\hline Controle & 0 & 2,5 & 2,5 & 0 & 0 & 0 \\
\hline Corante & 0 & 2,5 & 2,5 & 0 & 0 & 0 \\
\hline Laser & 0 & 2,5 & 2,5 & 0 & 1 & 0 \\
\hline PDT & 0 & 2,5 & 2,5 & 0 & 0 & 0 \\
\hline
\end{tabular}

Tabela 5.9 - Análise semi-quantitativa de intensidade de citoqueratina 10 em 5 dias

\begin{tabular}{|c|c|c|c|c|c|c|}
\hline \multirow[b]{2}{*}{5 dias } & \multicolumn{3}{|c|}{ Epitélio íntegro } & \multicolumn{3}{|c|}{ Epitélio migrado } \\
\hline & Basal & Espinhosa & Superficial & Basal & Espinhosa & Superficial \\
\hline Controle & 0 & 3 & 3 & 0 & 0,5 & 0 \\
\hline Corante & 0 & 3 & 3 & 0 & 0,5 & 0,5 \\
\hline Laser & 0 & 3 & 3 & 0 & 1,5 & 1 \\
\hline PDT & 0 & 2,5 & 2,5 & 0 & 0 & 0 \\
\hline
\end{tabular}

Tabela 5.10 - Análise semi-quantitativa de intensidade de citoqueratina 10 em 7 dias

\begin{tabular}{|c|c|c|c|c|c|c|}
\hline \multirow[b]{2}{*}{7 dias } & \multicolumn{3}{|c|}{ Epitélio íntegro } & \multicolumn{3}{|c|}{ Epitélio migrado } \\
\hline & Basal & Espinhosa & Superficial & Basal & Espinhosa & Superficial \\
\hline Controle & 0 & 2,5 & 2,5 & 0 & 2,5 & 2,5 \\
\hline Corante & 0 & 2 & 2 & 0 & 2 & 3 \\
\hline Laser & 0 & 2 & 2,5 & 0 & 2,5 & 2,5 \\
\hline PDT & 0 & 3 & 3 & 0 & 3 & 3 \\
\hline
\end{tabular}


Tabela 5.11 - Análise semi-quantitativa de intensidade de citoqueratina 10 em 14 dias

\begin{tabular}{|c|c|c|c|c|c|c|}
\hline \multirow[b]{2}{*}{14 dias } & \multicolumn{3}{|c|}{ Epitélio íntegro } & \multicolumn{3}{|c|}{ Epitélio migrado } \\
\hline & Basal & Espinhosa & Superficial & Basal & Espinhosa & Superficial \\
\hline Controle & 0 & 3 & 3 & 0 & 3 & 3 \\
\hline Laser & 0 & 2,5 & 3 & 0 & 3 & 3 \\
\hline PDT & 0 & 2,5 & 2,5 & 0 & 3 & 3 \\
\hline Corante & 0 & 2,5 & 2,5 & 0 & 2,5 & 2,5 \\
\hline
\end{tabular}




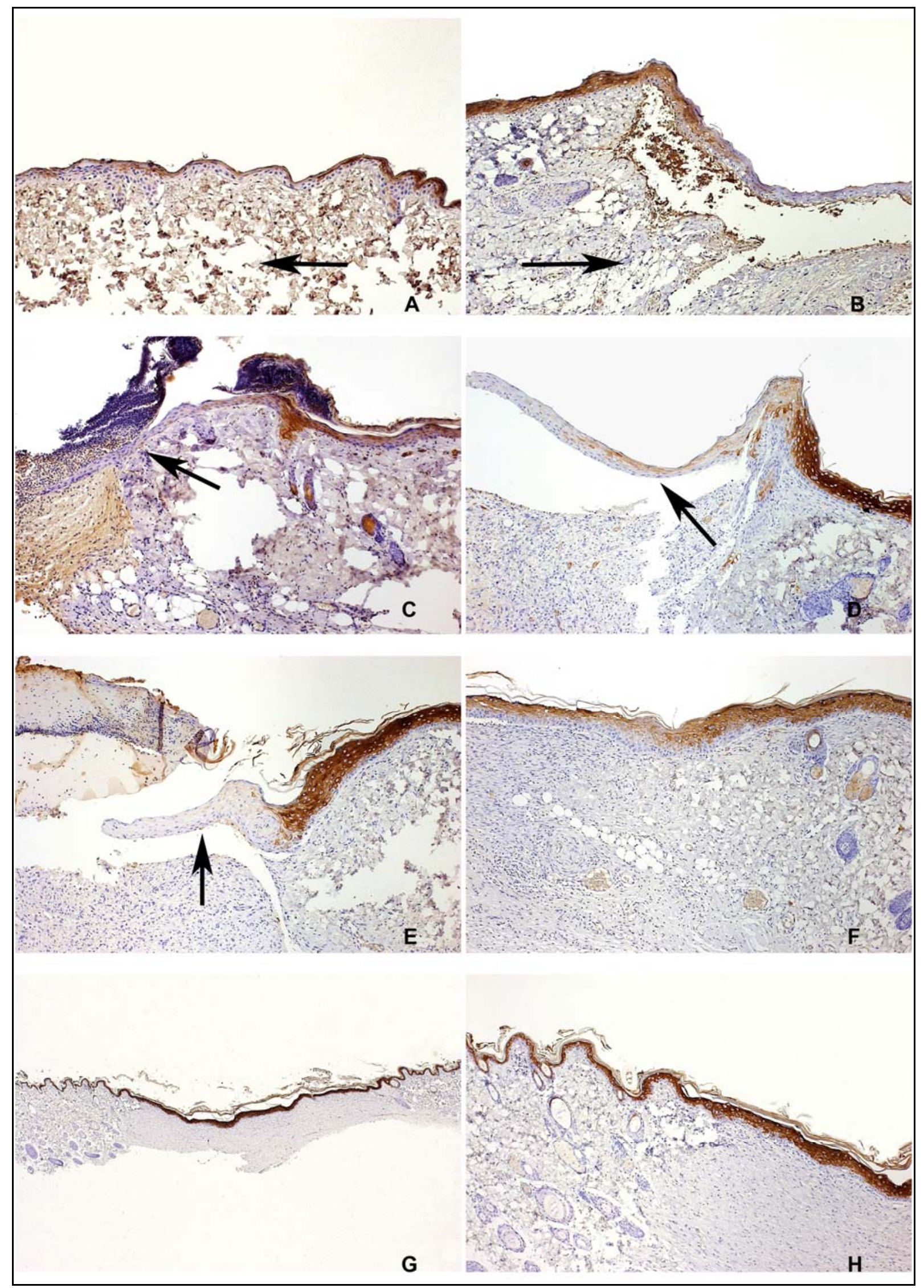

Figura 5.3 
Figura 5.3 - A - Controle 24h. O padrão de marcação de citoqueratina 10 muda gradativamente de intenso para fraco conforme se aproxima da ferida (direção da seta) (Aumento 10X); B Corante $72 \mathrm{~h}$. Padrão de marcação de citoqueratina 10. Marcação alterna de intensa para fraca conforme se aproxima da ferida (direção da seta) (Aumento 10X); C - PDT 72h. Ausência de expressão de citoqueratina 10 na região da língua epitelial (seta) (Aumento 10X); D - Laser 5 dias. Expressão de citoqueratina 10 na região da língua epitelial (seta) (Aumento 10X); E - PDT 5 dias. Ausência de expressão de citoqueratina 10 na região da língua epitelial (Aumento 10X); F - Corante 7 dias. Ausência de expressão de citoqueratina 10 na região basal do epitélio (Aumento 10X); G - Laser 14 dias. Padrão de marcação de citoqueratina 10 semelhante ao longo de todo epitélio (Aumento 2,5X); H Laser 14 dias. Padrão de marcação de citoqueratina 10 na transição entre epitélio íntegro e aquele que recobre o local onde se encontrava a ferida (Aumento 10X)

\subsection{Citoqueratina 14}

\section{- 24 horas após a realização da cirurgia}

O epitélio íntegro de todos os cortes expressou citoqueratina 14 nas camadas basal e espinhosa, porém não na camada superficial. Não foram notadas diferenças marcantes na intensidade de marcação entre os grupos, com exceção do grupo Corante que apresentou uma marcação menos intensa do que a observada nos outros grupos. Todas as camadas do epitélio migrado expressaram citoqueratina 14 neste tempo experimental, exceto a camada superficial do grupo Corante. As outras camadas apresentaram intensidade de marcação semelhante entre os grupos, sendo esta intensa, a não ser para o grupo Corante, onde foi moderada para a camada basal e fraca para a espinhosa. O grupo PDT também apresentou marcação de fraca a moderada para a camada superficial, em contraste com as dos outros grupos, cujas marcações foram intensas. 


\section{- 72 horas após a realização da cirurgia}

O epitélio íntegro de todos os cortes expressou citoqueratina 14 em suas camadas basal e espinhosa, porém não em sua camada superficial. Não foram notadas diferenças significantes na intensidade de marcação entre os grupos estudados. Diferentemente do epitélio íntegro, o epitélio migrado expressou citoqueratina 14 em todos os seus estratos, com marcação de moderada a intensa, não havendo diferenças marcantes entre os grupos estudados (Figura 5.4A).

\section{- 5 dias após a realização da cirurgia}

O epitélio íntegro de todos os cortes expressou citoqueratina 14 em seus estratos basal e espinhoso, com marcação forte e fraca, respectivamente. Não houve expressão no estrato superficial deste epitélio. O epitélio migrado expressou a proteína em todos seus estratos, com intensidade de marcação de moderada a intensa, e sem diferenças marcantes entre os grupos analisados (Figura 5.4B).

\section{- 7 dias após a realização da cirurgia}

Não foi notada expressão de citoqueratina 14 no estrato superficial do epitélio íntegro dos cortes. As camadas basal e espinhosa apresentavam marcação moderada e fraca, respectivamente para todos os grupos. O epitélio migrado expressou citoqueratina 14 em todas suas camadas para todos os grupos, sendo a intensidade de marcação de moderada à intensa para o grupo PDT e moderada para todos os outros (Figura $5.4 \mathrm{C}$ ). 


\section{- 14 dias após a realização da cirurgia}

O epitélio íntegro avaliado mostrou expressão semelhante de citoqueratina 14 entre os grupos, sendo que não houve expressão em sua camada superficial e houve marcação mais forte para a camada basal, quando comparada à camada espinhosa deste epitélio. O epitélio migrado, já mais maduro neste tempo, expressou citoqueratina 14 nas camadas basal e espinhosa para todos os grupos, porém o grupo Controle apresentou marcação intensa na camada superficial deste epitélio (Figura 5.4D) e os grupos Laser e PDT apresentaram marcação de fraca a moderada e fraca, respectivamente. A camada superficial do epitélio migrado no grupo Corante não expressou citoqueratina 14, e sua camada espinhosa também apresentou marcação mais fraca do que os outros grupos.

A análise semi-quantitativa das lâminas marcadas com citoqueratina 14 está relacionada nas tabelas 5.12 a 5.16 de acordo com os tempos de sacrifício e locais: camadas basal, espinhosa e superficial dos epitélios íntegro e migrado.

Tabela 5.12 - Análise semi-quantitativa de intensidade de citoqueratina 14 em 24 horas

\begin{tabular}{c|ccc|ccc}
\hline & \multicolumn{3}{|c|}{ Epitélio íntegro } & \multicolumn{3}{c}{ Epitélio migrado } \\
24 horas & Basal & Espinhosa & Superficial & Basal & Espinhosa & Superficial \\
\hline Controle & 3 & 2 & 0 & 3 & 3 & 3 \\
\hline Corante & 2 & 1 & 0 & 2 & 1 & 0 \\
\hline Laser & 3 & 2 & 0 & 3 & 3 & 3 \\
\hline PDT & 2,5 & 2,5 & 0 & 3 & 2,5 & 1,5 \\
\hline
\end{tabular}


Tabela 5.13 - Análise semi-quantitativa de intensidade de citoqueratina 14 em 72 horas

\begin{tabular}{c|ccc|ccc}
\hline & \multicolumn{3}{|c|}{ Epitélio íntegro } & \multicolumn{3}{c}{ Epitélio migrado } \\
72 horas & Basal & Espinhosa & Superficial & Basal & Espinhosa & Superficial \\
\hline Controle & 3 & 1,5 & 0 & 3 & 3 & 3 \\
\hline Corante & 2,5 & 1 & 0 & 2,5 & 2,5 & 2,5 \\
\hline Laser & 2 & 1 & 0 & 2,5 & 2,5 & 2,5 \\
\hline PDT & 2,5 & 1 & 0 & 2,5 & 2 & 2 \\
\hline
\end{tabular}

Tabela 5.14 - Análise semi-quantitativa de intensidade de citoqueratina 14 em 5 dias

\begin{tabular}{c|ccc|ccc}
\hline & \multicolumn{3}{|c|}{ Epitélio íntegro } & \multicolumn{3}{c}{ Epitélio migrado } \\
$\mathbf{5}$ dias & Basal & Espinhosa & Superficial & Basal & Espinhosa & Superficial \\
\hline Controle & 3 & 1 & 0 & 2,5 & 2,5 & 2,5 \\
\hline Corante & 3 & 1 & 0 & 2 & 2 & 2 \\
\hline Laser & 3 & 1,5 & 0 & 2,5 & 2,5 & 2,5 \\
\hline PDT & 3 & 1 & 0 & 2 & 2 & 2 \\
\hline
\end{tabular}

Tabela 5.15 - Análise semi-quantitativa de intensidade de citoqueratina 14 em 7 dias

\begin{tabular}{c|ccc|ccc}
\hline & \multicolumn{3}{|c|}{ Epitélio íntegro } & \multicolumn{3}{c}{ Epitélio migrado } \\
$\mathbf{7}$ dias & Basal & Espinhosa & Superficial & Basal & Espinhosa & Superficial \\
\hline Controle & 2 & 1 & 0 & 2 & 2 & 2 \\
\hline Corante & 2 & 1 & 0 & 2 & 2 & 2 \\
\hline Laser & 2 & 1 & 0 & 2 & 2 & 2 \\
\hline PDT & 2,5 & 1 & 0 & 2,5 & 2,5 & 2,5 \\
\hline
\end{tabular}

Tabela 5.16 - Análise semi-quantitativa de intensidade de citoqueratina 14 em 14 dias

\begin{tabular}{|c|c|c|c|c|c|c|}
\hline \multirow[b]{2}{*}{14 dias } & \multicolumn{3}{|c|}{ Epitélio íntegro } & \multicolumn{3}{|c|}{ Epitélio migrado } \\
\hline & Basal & Espinhosa & Superficial & Basal & Espinhosa & Superficial \\
\hline Controle & 3 & 2 & 0 & 3 & 3 & 3 \\
\hline Corante & 2 & 0,5 & 0 & 2 & 1 & 0 \\
\hline Laser & 2,5 & 1,5 & 0 & 3 & 3 & 1,5 \\
\hline PDT & 2,5 & 1,5 & 0 & 2,5 & 2,5 & 1 \\
\hline
\end{tabular}




\section{$5.6 \mathrm{p} 63$}

- 24 horas após a realização da cirurgia

A região próxima à ferida expressou a proteína p63 assim como a região distante da mesma. Não foram observadas diferenças significantes sobre a porcentagem de células que expressaram p63 entre os grupos analisados neste tempo experimental.

\section{- 72 horas após a realização da cirurgia}

Novamente notou-se expressão de p63 nas regiões do epitélio próximo e distante da ferida. Neste tempo cirúrgico pôde ser notado maior número de células marcadas intensamente nos grupos Laser e PDT (Figura 5.4E), se comparados aos outros grupos estudados.

\section{- 5 dias após a realização da cirurgia}

As regiões do epitélio próximo e distante da injúria expressaram p63, sem diferenças marcantes no número de células marcadas fraca, moderada ou intensamente. Para os grupos Corante e PDT já era possível avaliar a região por sobre a ferida (Figura 5.4F). Nesta região, ambos grupos expressaram p63, sendo que para o grupo PDT, o número de células marcadas intensamente foi maior. 


\section{- 7 dias após a realização da cirurgia}

As regiões do epitélio próximo e distante da ferida expressaram p63, bem como o epitélio recém-formado por sobre a ferida. Não foram notadas diferenças marcantes no número de células e intensidade de marcação entre os grupos avaliados (Figura 5.4G).

\section{- 14 dias após a realização da cirurgia}

Como no tempo anterior, todas as regiões do epitélio avaliadas expressaram p63. Não houve diferenças marcantes entre os grupos, sendo que o epitélio que recobriu a região anteriormente acometida pela injúria, no grupo Laser, apresentou maior número de células marcadas intensamente, em comparação com os outros grupos (Figura $5.4 \mathrm{H})$.

A análise semi-quantitativa das lâminas marcadas com p63 está relacionada nas tabelas 5.17 a 5.21 , de acordo com o método e divisão do epitélio préestabelecidos (Figura 4.3). 
Tabela 5.17 - Análise semi-quantitativa de intensidade de p63 de acordo com o número de células marcadas positivamente e regiões do epitélio analisadas no tempo de 24 horas

\begin{tabular}{|c|c|c|c|c|}
\hline 24 horas & Região & Fraca & Moderada & Intensa \\
\hline \multirow[t]{4}{*}{ Controle } & 1 & 1 & 2 & 2,5 \\
\hline & 2 & 1 & 2,5 & 1,5 \\
\hline & 3 & 1 & 1,5 & 3 \\
\hline & 4 & 1 & 2 & 2,5 \\
\hline \multirow[t]{4}{*}{ Corante } & 1 & 1 & 1,5 & 3 \\
\hline & 2 & 1 & 1 & 3,5 \\
\hline & 3 & 1 & 2,5 & 2 \\
\hline & 4 & 1,5 & 2 & 2 \\
\hline \multirow[t]{4}{*}{ Laser } & 1 & 1 & 1,5 & 3 \\
\hline & 2 & 1 & 2 & 2,5 \\
\hline & 3 & 0,5 & 1,5 & 2,5 \\
\hline & 4 & 1 & 2,5 & 2 \\
\hline \multirow[t]{4}{*}{ PDT } & 1 & 1 & 2,5 & 2,5 \\
\hline & 2 & 1 & 2 & 2,5 \\
\hline & 3 & 1 & 2,5 & 2 \\
\hline & 4 & 1 & 2,5 & 2,5 \\
\hline
\end{tabular}

Tabela 5.18 - Análise semi-quantitativa de intensidade de p63 de acordo com o número de células marcadas positivamente e regiões do epitélio analisadas no tempo de 72 horas

\begin{tabular}{|c|c|c|c|c|}
\hline 72 horas & Região & Fraca & Moderada & Intensa \\
\hline \multirow[t]{4}{*}{ Controle } & 1 & 1 & 2 & 2,5 \\
\hline & 2 & 1 & 1,5 & 2,5 \\
\hline & 3 & 1 & 1,5 & 2 \\
\hline & 4 & 1 & 1,5 & 2,5 \\
\hline \multirow[t]{4}{*}{ Corante } & 1 & 1 & 2 & 2,5 \\
\hline & 2 & 1 & 2 & 2 \\
\hline & 3 & 1 & 2 & 2 \\
\hline & 4 & 1 & 2 & 2,5 \\
\hline \multirow[t]{4}{*}{ Laser } & 1 & 1 & 1 & 3,5 \\
\hline & 2 & 1 & 1 & 3,5 \\
\hline & 3 & 1 & 2 & 3 \\
\hline & 4 & 1 & 2 & 3 \\
\hline \multirow[t]{4}{*}{ PDT } & 1 & 1 & 2 & 3 \\
\hline & 2 & 1 & 2 & 3 \\
\hline & 3 & 1 & 1 & 3,5 \\
\hline & 4 & 1 & 1 & 3,5 \\
\hline
\end{tabular}


Tabela 5.19 - Análise semi-quantitativa de intensidade de p63 de acordo com o número de células marcadas positivamente e regiões do epitélio analisadas no tempo de 5 dias

\begin{tabular}{|c|c|c|c|c|}
\hline 5 dias & Região & Fraca & Moderada & Intensa \\
\hline \multirow[t]{4}{*}{ Controle } & 1 & 1 & 2,5 & 2 \\
\hline & 2 & 1 & 2,5 & 1,5 \\
\hline & 3 & 1 & 2,5 & 2 \\
\hline & 4 & 1 & 2 & 2 \\
\hline \multirow[t]{5}{*}{ Corante } & 1 & 1 & 2,5 & 1,5 \\
\hline & 2 & 1 & 3 & 1 \\
\hline & 3 & 1 & 3 & 2 \\
\hline & 4 & 1 & 2,5 & 2 \\
\hline & 5 & 0,5 & 1 & 1 \\
\hline \multirow[t]{4}{*}{ Laser } & 1 & 1 & 2,5 & 1,5 \\
\hline & 2 & 1,5 & 3 & 1,5 \\
\hline & 3 & 1 & 3 & 1,5 \\
\hline & 4 & 1 & 3 & 1,5 \\
\hline \multirow[t]{5}{*}{ PDT } & 1 & 1 & 2,5 & 1,5 \\
\hline & 2 & 1 & 2,5 & 1,5 \\
\hline & 3 & 1 & 3 & 1,5 \\
\hline & 4 & 1 & 2,5 & 1,5 \\
\hline & 5 & 1 & 1,5 & 2 \\
\hline
\end{tabular}

Tabela 5.20 - Análise semi-quantitativa de intensidade de p63 de acordo com o número de células marcadas positivamente e regiões do epitélio analisadas no tempo de 7 dias

\begin{tabular}{|c|c|c|c|c|}
\hline 7 dias & Região & Fraca & Moderada & Intensa \\
\hline \multirow[t]{5}{*}{ Controle } & 1 & 1 & 2,5 & 2 \\
\hline & 2 & 1 & 2 & 2 \\
\hline & 3 & 1 & 2,5 & 1,5 \\
\hline & 4 & 1 & 2,5 & 2 \\
\hline & 5 & 1 & 3,5 & 1,5 \\
\hline \multirow[t]{5}{*}{ Corante } & 1 & 1 & 2,5 & 1,5 \\
\hline & 2 & 1 & 3 & 1,5 \\
\hline & 3 & 1 & 2,5 & 1,5 \\
\hline & 4 & 1 & 2,5 & 1,5 \\
\hline & 5 & 1 & 2,5 & 2 \\
\hline \multirow[t]{5}{*}{ Laser } & 1 & 1 & 2,5 & 1,5 \\
\hline & 2 & 1 & 2,5 & 1,5 \\
\hline & 3 & 1,5 & 2,5 & 1,5 \\
\hline & 4 & 1,5 & 2,5 & 1,5 \\
\hline & 5 & 1 & 2,5 & 2 \\
\hline \multirow[t]{5}{*}{ PDT } & 1 & 1 & 2,5 & 1,5 \\
\hline & 2 & 1,5 & 2,5 & 1 \\
\hline & 3 & 1 & 2,5 & 1,5 \\
\hline & 4 & 1,5 & 2,5 & 1 \\
\hline & 5 & 0,5 & 1 & 1 \\
\hline
\end{tabular}


Tabela 5.21 - Análise semi-quantitativa de intensidade de p63 de acordo com o número de células marcadas positivamente e regiões do epitélio analisadas no tempo de 14 dias

\begin{tabular}{|c|c|c|c|c|}
\hline 14 dias & Região & Fraca & Moderada & Intensa \\
\hline \multirow[t]{5}{*}{ Controle } & 1 & 1 & 2 & 2 \\
\hline & 2 & 1 & 2 & 2 \\
\hline & 3 & 1 & 2 & 2 \\
\hline & 4 & 1 & 2 & 2 \\
\hline & 5 & 1 & 2 & 2 \\
\hline \multirow[t]{5}{*}{ Corante } & 1 & 1 & 2,5 & 1,5 \\
\hline & 2 & 1 & 2 & 2 \\
\hline & 3 & 1 & 3 & 1 \\
\hline & 4 & 1 & 3 & 1,5 \\
\hline & 5 & 1 & 3 & 1,5 \\
\hline \multirow[t]{5}{*}{ Laser } & 1 & 1 & 2 & 2 \\
\hline & 2 & 1 & 2 & 2 \\
\hline & 3 & 1 & 2 & 2,5 \\
\hline & 4 & 1 & 2 & 2,5 \\
\hline & 5 & 1 & 2 & 3 \\
\hline \multirow[t]{5}{*}{ PDT } & 1 & 1 & 2,5 & 1,5 \\
\hline & 2 & 1 & 2,5 & 2 \\
\hline & 3 & 1 & 2,5 & 1,5 \\
\hline & 4 & 1 & 2,5 & 1,5 \\
\hline & 5 & 1 & 3 & 1 \\
\hline
\end{tabular}




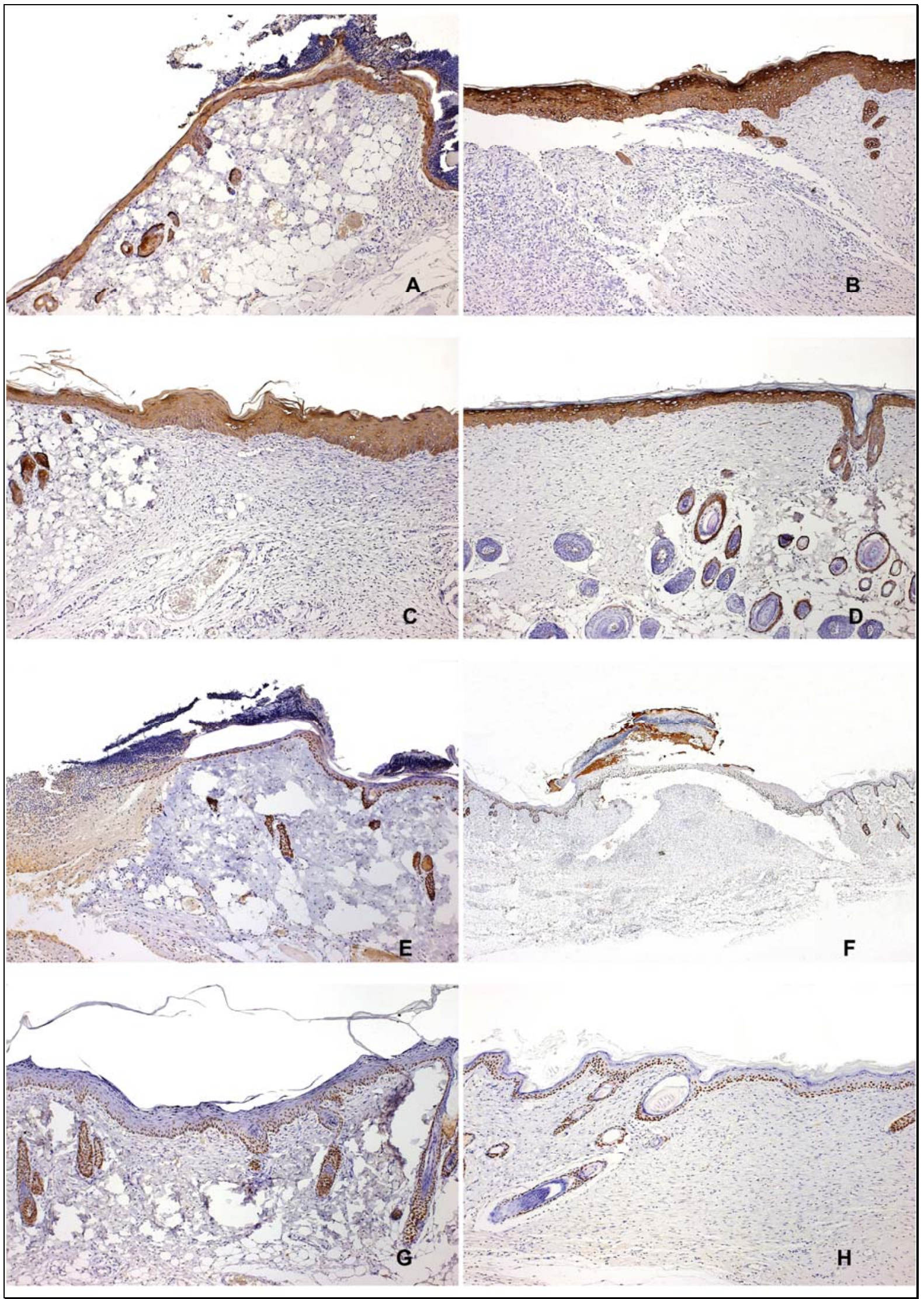

Figura 5.4 
Figura 5.4 - A - Corante $72 \mathrm{~h}$. Epitélio migrado expressando citoqueratina 14 em todos os seus estratos (Aumento 10X); B - Laser 5 dias. Epitélio migrado expressando citoqueratina 14 em todos os seus estratos (Aumento 10X); C - Laser 7 dias. Expressão de citoqueratina $14 \mathrm{em}$ todos os extratos do epitélio migrado com intensidade de marcação moderada (Aumento 10X); D - Controle 14 dias. Expressão de citoqueratina 14 no epitélio migrado com intensidade de marcação intensa na camada superficial do mesmo (Aumento 10X); E - PDT 72h. Expressão de p63 na língua epitelial com intensidade de marcação intensa (Aumento 10X); $\mathrm{F}$ - Corante 5 dias. Expressão de p63 na área que recobre a ferida (Aumento 2,5X); $\mathrm{G}$ - Laser 7 dias. Expressão de p63 no epitélio que recobre a área previamente ulcerada (Aumento 10X); H - Laser 14 dias. Grande número de células do epitélio que recobre a ferida expressando p63 com intensidade de marcação intensa (Aumento 10X) 


\section{DISCUSSÃO}

Os lasers de baixa potência têm sido uma alternativa para acelerar a reparação tecidual de feridas cutâneas, sendo que várias pesquisas clínicas comprovam seus benefícios (AL-WATBAN; ZHANG; ANDRES, 2007; GÁL et al., 2006; RIBEIRO et al., 2009; SCHINDL et al., 1998; SCHINDL; SCHINDL; SCHINDL, 1997; STADLER 2001).

Neste estudo, foi notada diferença estatisticamente significante $(p<0,05)$ para a área final encontrada no grupo laser, sendo esta menor aos quatorze dias, se comparada às áreas finais dos outros grupos. Para o grupo PDT não foram encontradas diferenças estatisticamente significantes se comparados aos outros grupos ao longo dos períodos estudados.

A análise clínica das feridas mostrou que aquelas que tomaram contato com o laser, seja pela LILT ou pelo PDT, apresentaram crostas geralmente mais escuras e, aparentemente, mais espessas. Quando foi realizada a análise morfológica em HE de todas as feridas, este aspecto pôde ser comprovado. Muitos dos cortes pertencentes aos grupos PDT e Laser apresentaram maior quantidade de fibrina, sendo esta mais bem organizada, na região da crosta (Figura 5.2B).

Clinicamente, pôde-se observar a presença deste corante até o tempo experimental de 24 horas. Após este tempo, as feridas do grupo Corante comportaram-se semelhantemente àquelas do grupo Controle, não havendo diferenças estatisticamente significantes quando comparadas clinicamente e não havendo grandes diferenças quando analisadas microscopicamente. 
Ao final de quatorze dias, todas as feridas já se encontravam reparadas e, microscopicamente, sem diferenças entre elas. No entanto, ao longo do processo de reparação estudado, puderam ser notadas algumas diferenças.

Aos cinco dias de pós-operatório, o edema encontrado era menor para o grupo Laser e ligeiramente menor para o grupo PDT, quando comparados aos outros dois grupos. Já aos sete dias, o grupo PDT apresentava o maior score de edema entre os grupos. A necrose, a partir de 72 horas, foi relativamente menor para o grupo Laser do que para todos os outros, que apresentaram um score semelhante e que foi se igualar ao grupo Laser apenas aos quatorze dias.

O infiltrado inflamatório também foi menor para o grupo Laser às 72 horas e aos sete dias, igualando-se aos outros grupos aos quatorze dias, com exceção do grupo controle, que ainda apresentava uma ligeira inflamação predominantemente crônica. Em um estudo de Do Nascimento et al. (2004), foi observada fase inflamatória menos intensa e mais avançada nos animais que sofreram LILT se comparados ao controle. A inflamação ainda foi menos intensa quando o comprimento de onda $670 \mathrm{~nm}$ foi usado ou quando a potência de $2 \mathrm{~mW}$ foi usada. Já havia sido postulada a instalação mais breve da resposta inflamatória quando comprimentos de onda mais curtos são utilizados (BASFORD 1995; PINHEIRO, 1998; RIGAU, 1996).

Em nosso estudo foi também avaliada a re-epitelização, por meio da presença e tamanho da língua epitelial. A re-epitelização esteve sempre à frente com o grupo Laser, e já podia ser notada 24 horas após realização do procedimento cirúrgico. Setenta e duas horas após, a re-epitelização mostrava-se semelhante para os grupos Laser e PDT, sendo maior para estes do que para os grupos Controle e Corante. Aos cinco dias, a re-epitelização do grupo Laser estava quase completa e 
tornou-se completa aos sete dias, enquanto que os outros grupos mostraram reepitelização completa somente aos quatorze dias.

Assim, pôde-se confirmar que o grupo Laser apresentou reparação tecidual satisfatória, tendo formação completa de epitélio previamente aos outros grupos. Em situações em que o paciente corre risco de vida e o fechamento da ferida é essencial para sua sobrevivência, o laser representa uma forte alternativa. A presença de fibroblastos jovens também é uma indicação de aceleração do processo de reparação, sendo que o número destas células foi maior para os grupos Laser e PDT em 24 horas. Já aos 14 dias de pós-operatório, foi encontrado maior número de fibroblastos jovens nos grupos Controle e Corante, indicando reparação mais lenta do que nos outros grupos, uma vez que neste tempo experimental, os grupos Laser e PDT já apresentavam colagenização completa e em remodelação.

A reparação tecidual decorrente da LILT, no entanto, mostrou-se diferente daquela apresentada pela PDT. Isto significa que a interação do laser com o tecido é mudada em vários aspectos quando intermediada pela aplicação do corante azul de metileno. Apesar da dose, comprimento de onda e potência do aparelho laser terem sido as mesmas para ambos os tratamentos, as consequências para a reparação tecidual foram outras.

Os estudos que avaliam o efeito da PDT na reparação tecidual mostram resultados contraditórios. Jefferis, Chevretton e Berenbaum (1991) e Stern et al. (1990) em modelos animais, demonstraram que a PDT tem papel significativo na reparação tecidual, incluindo aumento da formação do tecido de granulação primário, mais rápida re-epitelização e redução da necrose de fibras musculares, tecido mucoso e inflamação. Já Kübler et al. (1996), relatou demora na reparação 
tecidual após a terapia foto-dinâmica e Parekh et al. (1999) concluiu que uma única dose de PDT no processo de reparação tecidual é pouco influente ou transitória.

O corante foto-sensibilizador utilizado neste estudo foi o azul de metileno a 0,01\%. O uso deste corante é seguro ou menos tóxico do que o de outros corantes (CHAN; LAI, 2003), e vem sendo utilizado na medicina desde 1928 por ter propriedades de foto-inativação viral (SCHULTZ; KRUEGER, 1928).

A seletividade desses corantes foto-sensibilizadores se dá por células cujo metabolismo encontra-se aumentado. Assim, células neoplásicas, por terem metabolismo acelerado, coram-se mais facilmente do que células normais e, tornamse, portanto, sensíveis à terapia foto-dinâmica (PENG et al., 1997).

No caso da reparação tecidual, sabe-se que logo após uma injúria, há uma fase denominada "ebb", que indica atividade biológica diminuída, com baixa produção de calor e baixos níveis de hormônios e fatores de crescimento. Após esta fase, há uma fase de transição denominada "turn", que intermedeia as fases "ebb" e "flow". A fase "flow" é caracterizada por resposta hiper-metabólica com aumento da produção de calor, catabolismo de proteínas, lipólise, etc (CUTHBERTSON; FELL; TILSTONE, 1972). Zhang et al. (2006) mostraram aumento do turnover de proteínas no sétimo dia após injúria se comparado aos primeiros três dias. Os autores concluíram que a fase flow se iniciou a partir do sétimo dia e que esta é caracterizada por síntese protéica ao invés de aumento na proliferação celular.

Assim, durante esta fase hiper-metabólica ("flow"), as células envolvidas na reparação tecidual poderiam tornar-se mais suscetíveis ao corante aplicado. Neste estudo, quando realizada a análise estatística dos valores encontrados para o fator de forma, perímetro e área das lesões, não foram encontradas diferenças estatisticamente significantes quando se comparou o grupo PDT aos grupos 
Controle e Corante, sugerindo que a reparação tecidual frente à terapia fotodinâmica não apresenta melhora em se tratando de fechamento mais rápido da ferida. No entanto, a aplicação da terapia foto-dinâmica foi dada em dose única e não levou a uma demora na reparação tecidual. Porém, deve-se analisar seu efeito quando aplicada múltiplas vezes, pois como visto, o corante foto-sensibilizador tem afinidade por células de metabolismo acelerado, e se aplicado constantemente, poderia tornar-se mais incorporado pelas células que desempenham seu papel na reparação, principalmente na fase final (fase "flow"), impedindo o curso normal do processo, uma vez que as espécies reativas de oxigênio formadas durante a terapia foto-dinâmica causam morte celular em altas doses.

Apesar disto, um estudo recente mostra que doses controladas e relativamente pequenas destas formas reativas de oxigênio podem desempenhar papel importante em desencadear vários processos celulares, como a proliferação de fibroblastos. Estas espécies reativas de oxigênio podem ser vistas, portanto, também como mediadores de processos fisiológicos, e não apenas como agentes que causam morte celular (LUBART; FRIEDMANN; LAVIE, 1999). Assim, parece haver uma dose ideal a ser atingida entre o corante foto-sensibilizador e a fonte de luz a serem utilizados para que a reparação tecidual se torne mais rápida, e não atrasada.

Além disso, deve ser analisado o efeito de desinfecção promovido pela PDT. Segundo o estudo de Silva et al. (2004), o efeito anti-microbiano provocado pela PDT é um ponto positivo para a reparação tecidual, e pode não apenas ajudar na aceleração da reparação tecidual, mas também agir de maneira a evitar infecções locais durante o processo reparacional. Em nosso estudo não foi avaliado o aspecto 
de infecção da ferida, mas este efeito anti-microbiano poderia justificar o uso da PDT em reparação tecidual, mesmo que não haja aceleração da mesma quando utilizado.

Neste estudo, apesar de a PDT não ter apresentado uma reparação mais rápida das feridas, também não provocou atraso na mesma, levando à reparação tecidual semelhante àquela do grupo controle. Portanto, se somado ao seu efeito anti-microbiano sua ação não-prejudicial, a PDT pode se tornar uma alternativa para o tratamento de várias lesões sujeitas à infecção por diversos microorganismos. Desta maneira, devem ser realizados novos estudos nesta área, conjugando a reparação tecidual com as infecções próprias de feridas cutâneas.

A densidade de energia do laser utilizada neste estudo foi a mesma para promover a LILT e a terapia foto-dinâmica. Isto foi convencionado de modo que a densidade de energia não se tornasse mais uma variável e seus resultados pudessem ser facilmente comparados entre si. No entanto, sabe-se que as densidades de energia utilizadas para acelerar a reparação tecidual com laser são bem menores do que a utilizada neste estudo (BISHT et al., 1994; KANA et al., 1981; PESSOA et al. 2004; REIS et al., 2008). Portanto, apesar da LILT aqui aplicada ter tido resultado satisfatório na reparação tecidual das excisões, acreditase que densidades de energia menores possam apresentar resultados ainda melhores.

As diversas citoqueratinas são expressas através de específicos grupos de polipeptídeos característicos de determinados tipos celulares e, portanto permitem com que possamos distinguir e classificar as células epiteliais de acordo com seu padrão expresso de citoqueratinas (MOLL et al., 1982a). As citoqueratinas (CKs) 5 e 14 são as principais proteínas estruturais nos queratinócitos basais em proliferação. Através de sinais ainda pouco esclarecidos, os queratinócitos basais migram para a 
camada espinhosa, perdem sua atividade mitótica e começam a sintetizar uma nova série de proteínas estruturais e enzimas características da queratinização (corneificação), entre elas as citoqueratinas 1 e 10. (CANDI; SCHIMIDT; MELINO, 2005).

Neste estudo, a localização das citoqueratinas não se mostrou diferente da esperada para os epitélios distantes da ferida, sendo que no epitélio íntegro, em nenhum tempo estudado a camada basal apresentou marcação por citoqueratina 10 e, em nenhum tempo a camada superficial apresentou marcação pela citoqueratina 14. Ainda para o epitélio íntegro, distante da ferida, nenhuma diferença marcante pôde ser observada entre os grupos ao longo dos tempos estudados, tanto para citoqueratina 10 quanto para 14.

Isto sugere que a aplicação do laser, do corante ou de ambos não afeta a expressão das citoqueratinas 10 e 14 no epitélio distante da ferida, o que indica não haver interferência no processo de proliferação e diferenciação epitelial nesta localização.

Setenta e duas horas após a realização das excisões, já se notava marcação das células do estrato intermediário do epitélio migrado para o grupo Laser. Neste tempo, nenhum outro grupo apresentava marcação. Aos cinco dias, notava-se marcação mais intensa dos estratos intermediário e superficial do epitélio migrado para a citoqueratina 10 no grupo Laser, se comparado aos outros grupos. Aos sete e quatorze dias a marcação apresentava-se muito semelhante para todos os grupos.

A expressão de citoqueratina 10 no epitélio sugere a diferenciação dos queratinócitos, uma vez que esta citoqueratina é típica do estrato superficial e só é sintetizada após terem os queratinócitos basais migrado para a camada espinhosa (CANDI; SCHIMIDT; MELINO, 2005). Assim, a marcação por citoqueratina 10 no 
grupo Laser previamente àquela vista para os outros grupos confirma a maturação mais rápida do epitélio migrado neste grupo.

A marcação por citoqueratina 14 foi bastante semelhante entre os grupos para todos os tempos analisados. A citoqueratina 14 já se mostrava presente desde o tempo de 24 horas em todos os estratos do epitélio migrado e continuou presente durante os tempos de 72 horas, cinco, sete e quatorze dias. Aos quatorze dias apresentava marcação menos intensa no estrato superficial para os grupos Laser e PDT e nula para o grupo corante, sugerindo um epitélio já bastante diferenciado cuja camada superficial não mais expressa citoqueratina 14 nestes grupos.

Neste estudo não foram notadas diferenças significantes quanto à marcação de citoqueratina 14 no epitélio migrado entre os grupos Laser, PDT ou Corante.

O p63 é um marcador essencial das células basais progenitoras da epiderme e de seus anexos e está relacionado com a proliferação celular e migração durante a reparação tecidual (TSUJITA- KYUTOKU et al., 2003).

Noszczyk e Majewski (2001) estudaram a expressão do p63 em conjunto com outro marcador de proliferação celular, o Ki67, durante a regeneração normal da epiderme de humanos. Nos primeiros dias observados, sua expressão foi fraca na área da língua epitelial que invadia a crosta. Já aos cinco dias após a injúria, a expressão em queratinócitos basais era detectada, aumentando gradualmente ao longo dos dias. Vários dias após o fechamento das feridas, a expressão ainda era bastante forte nos queratinócitos basais e também em toda a camada espinhosa do epitélio.

Em nosso estudo, vinte e quatro horas após o estabelecimento das excisões, não foram notadas grandes diferenças com relação à intensidade ou área de marcação do p63 entre os grupos. Após setenta e duas horas, porém, a marcação 
continuava semelhante para os grupos Controle e Corante, enquanto o número de células intensamente marcadas no epitélio próximo da ferida era maior para os grupos Laser e PDT.

Aos cinco dias, não havia diferenças marcantes entre os grupos, sendo que a marcação se dava em todas as áreas analisadas e era predominantemente moderada. A marcação continuou predominantemente moderada durante os sete dias e sem diferenças marcantes entre os quatro grupos. Aos quatorze dias, a marcação do grupo Laser era predominantemente intensa, incluindo a área recém epitelizada, diferentemente dos outros grupos.

Assim, observou-se que a expressão de citoqueratinas 10 e 14, bem como do p63, em conjunto com a análise morfológica e histo-morfológica das feridas consistiram num método eficiente para a avaliação da LILT e PDT em reparação tecidual. Foi dada ênfase para a regeneração epitelial das feridas e, ao longo de todos os tempos, pôde ser observado processo distinto de reparação para cada um dos grupos estudados, sendo que foram observadas diferenças marcantes entre os grupos que receberam LILT e aqueles que receberam PDT. 


\section{CONCLUSÕES}

- A reparação tecidual das excisões que foram irradiadas com laser de baixa intensidade foi diferente da reparação tecidual das excisões que receberam terapia foto-dinâmica mediada pelo corante azul de metileno.

- A reparação tecidual encontrada no grupo que recebeu irradiação com laser em baixa intensidade mostrou-se acelerada, o que pôde ser confirmado por meio das análises morfológica, histo-morfológica e imunoistoquímica.

- A terapia foto-dinâmica com corante azul de metileno não apresentou aceleração da reparação tecidual, porém também não se mostrou mais lenta do que aquela observada para o grupo Controle ou Corante, devendo ser levadas em consideração suas vantagens anti-microbianas. 


\section{REFERÊNCIAS ${ }^{1}$}

Abergel RP, Lyons RF, Castel JC, Dwyer RM, Uitto J. Biostimulation of wound healing by lasers: experimental approaches in animal models and in fibroblast cultures. J Dermatol Surg Oncol 1987;13(2):127-33.

Ackroyd R, Brown NJ, Davis MF, Stephenson TJ, Stoddard CJ, Reed MW. Aminolaevulinic acid-induced photodynamic therapy in the treatment of dysplastic Barret's oesophagus and adenocarcinoma. Lasers Med Sci 1999;14:278-85.

Alexiades-Armenakas MR. Geronemus Laser-mediated photodynamic therapy of actinic cheilitis. J Drugs Dermatol 2004;3:548-51.

Allendorf JD, Bessler M, Huang J, Kayton ML, Laird D, Nowygrod R, et al. Heliumneon laser irradiation at fluences of 1,2 , and $4 \mathrm{~J} / \mathrm{cm} 2$ failed to accelerate wound healing as assessed by both wound contracture rate and tensile strength. Lasers Surg Med 1997;20(3):340-5.

Almeida HL Jr. Citoqueratinas. An Bras Dermatol 2004;79(2):135-45.

Almeida-Lopes L, Rigau J, Zângaro RA, Guidugli-Neto J, Jaeger MM. Comparison of the low level laser therapy effects on cultured human gingival fibroblasts proliferation using different irradiance and same fluence. Lasers Surg Med 2001;29(2):179-84.

Al-Watban FA, Zhang XY, Andres BL. Low-Level Laser Therapy Enhances Wound Healing in Diabetic Rats: A Comparison of Different Lasers. Photomed Laser Surg 2007;25(2):72-7.

Anneroth G, Hall G, Ryden H, Zetterqvist L. The effect of low energy infra-red laser radiation on wound healing in rats. Br J Oral Maxillofac Surg 1988;26:12-7.

${ }^{1}$ De acordo com o estilo Vancouver. Abreviatura de periódicos segundo base de dados MEDLINE. 
Asch BE, Burstein NA, Vidrich A, Sun TT. Identification of mouse mammary epithelial cells by immunofluorescence with rabbit and guinea pig antikeratin antisera. Proc Nat Acad Sci USA 1981;78(9):5643-7.

Augustin M, Bamberger C, Paul D, Schmale $\mathrm{H}$. Cloning and chromosomal mapping of the human p53- related KET gene to Chromosome 3q27 and its murine homolog Ket to mouse Chromosome 16, Mamm. Genome 1998;9:899-902.

Balasubramani M, Kumar TR, Babu M. Skin substitutes: A review. Burns 2001;27:534-44.

Bamberger C, Hafner A, Schmale H, Werner S. Expression of different p63 variants in healing skin wounds suggests a role of p63 in reepithelialization and muscle repair. Wound Rep Reg 2005;13:41-50.

Barbieri CE, Pietenpol JA. p63 and epithelial biology. Exp Cell Res 2006;312:695706.

Baribault $\mathrm{H}$, Price J, Miyai K, Oshima RG. Mid-gestational lethality in mice lacking keratin 8. Genes Dev 1993;7:1191-202.

Basford JR. Low intensity laser therapy: Still not an established clinical tool. Lasers Surg Med 1995;16:331-42.

Baxter GD, Bell AJ, Allen JM. Low level laser therapy: Current clinical practice in North Ireland. Physiotherapy 1992;77:171-8.

Beerens EGT, Slot TW, Van Der Leun JC. Rapid regeneration of the dermalepidermal junction after partial separation by vacuum. An electron microscopic study. J Invest Dermatol 1975;65:513-21.

Bellin RM, Huiatt TW, Critchley DR, Robson RM. Synemin may function to directly link muscle cell intermediate filaments to both myofibrillar Z-lines and costameres. J Biol Chem 2001;276(34):32330-7.

Berking C, Herzinger T, Flaig MJ, Brenner M, Borelli C, Degitz K. Actinic Cheilitis of the Lower Lip: A Prospective Study of 15 Patients. Dermatol Surg 2007;33:825-830. 
Bisht D, Gupta SC, Misra V, Mital VP, Sharma P. Effect of low intensity laser radiation on healing of open skin wounds in rats. Indian J Med Res 1994;100:43-6.

Brugnera Júnior A, Pinheiro ALB. Lasers na Odontologia moderna. São Paulo: Pancast; 1998.

Brunner HG, Hamel BC, Bokhoven HH. P63 gene mutations and human developmental syndromes. Am J Med Genet 2002;112:284-90.

Bruno T, Corbi N, Di Padova M, De Angelis R, Floridi A, Passananti C, et al. The RNA polymerase II core subunit 11 interacts with keratin 19, a component of the intermediate filament proteins. FEBS Lett 1999;453:273-7.

Candi E, Schimidt R, Melino G. The cornified envelope: a model of cell death in the skin. Nat Rev Mol Cell Biol 2005;6(4):328-40.

Carter WG, Kaur P, Gil SG, Gahr PJ, Wayner EA. Distinct functions for integrins alpha 3 beta 1 in focal adhesions and alpha 6 beta 4/bullous pemphigoid antigen in a new stable anchoring contact (SAC) of keratinocytes: relation to hemidesmosomes. J Cell Biol 1990;111:3141-54.

Caulin C, Ware CF, Magin TM, Oshima RG. Keratin-dependent, epithelial resistance to tumor necrosis factor-induced apoptosis. J Cell Biol 2000;149:17-22.

Chan Y, Lai CH. Bactericidal effects of different laser wavelengths on periodontopathic germs in photodynamic therapy. Lasers Med Sci 2003;18(1):1-5.

Chen YJ, Jeng JH, Lee BS, Chang HF, Chen KC, Lan WH. Effects of Nd:YAG laser irradiation on cultured human gingival fibroblasts. Lasers Surg Med 2002;27(5):4718.

Choi HR, Batsakis JG, Zhan F, Sturgis E, Luna MA, El-Naggar AK. Differential expression of p53 gene family members p63 and p73 in head and neck squamous tumorigenesis. Hum Pathol 2002;33(2):158-64.

Clark RA. The molecular and cellular biology of wound repair. New York: Plenum Press; 1996. 
Coates P, Adams CA, Cunliffe WJ, Mcginley KT, Eady EA, Leyden JJ, et al. Does oral isotretinoin prevent Propionibacterium acnes resistance? Dermatology 1997;195(Pt 1):4-9.

Conlan MJ, Rapley JW, Cobb CM. Biostimulation of wound healing by low-energy laser irradiation. A review. J Clin Periodontol 1996;23:492-6.

Coulombe PA, Bousquet O, Ma L, Yamada S, Wirtz D. The 'ins' and 'outs' of intermediate filament organization. Trends Cell Biol 2000;10:420-8.

Coulombe PA, Omary MB. "Hard"and "soft"principles defining the structure, function and regulation of keratin intermediate filaments. Curr Opin Cell Biol 2002;14(1):11022.

Croft CB, Tarin D. Ultrastructural features of wound healing in mouse skin. J Anat 1969;105:189-90.

Crook T, Nicholls JM, Brooks L, O'nions J, Allday MJ. High level expression of deltaN-p63: a mechanism for the inactivation of p53 in undifferentiated nasopharyngeal carcinoma (NPC)? Oncogene 2000;19:3439-44.

Cuthbertson DP, Fell GS, Tilstone WJ. Nutrition in the posttraumatic period. Nutr Metab 1972;14:92.

Dai X, Segre JA. Transcriptional control of epidermal specification and differentiation. Curr Opin Genet Dev 2004;14(5):485-91.

Davidson JM. Wound repair. J Hand Ther 1998;11:80-94.

De Castro JL, Pinheiro AL, Werneck CE, Soares CP. The effect of laser therapy on the proliferation of oral KB carcinoma cells: an in vitro study. Photomed Laser Surg 2005;23(6),586-9.

De Laurenzi V, Rossi A, Terrinoni A, Barcaroli D, Levrero M, Costanzo A, et al. p63 and p73 transactivate differentiation gene promoters in human keratinocytes.

Biochem Biophys Res Commun 2000;273(1):342-6.

Dellavalle RP, Egbert TB, Marchbank A, Su LJ, Lee LA, Walsh P. CUSP/p63 expression in rat and human tissues. J Dermatol Sci 2001;27:82-7. 
Demidova TN, Hamblin MR. Photodynamic therapy targeted to pathogens. Int J Immunopathol Pharmacol 2004;17(3):245-54.

Di Como CJ, Urist MJ, Babayan I, Drobnjak M, Hedvat CV, Teruya-Feldstein J, et al. p63 expression profiles in human normal and tumor tissues. Clin Cancer Res 2002;8:494-501.

Dohn M, Jiang J, Chen X. Receptor tyrosine kinase EphA2 is regulated by p53-family proteins and induces apoptosis. Oncogene 2001;20:6503-15.

Dohn M, Zhang S, Chen X. p63alpha and DeltaNp63alpha can induce cell cycle arrest and apoptosis and differentially regulate p53 target genes. Oncogene 2001;20:3193-205.

Do Nascimento PM, Pinheiro AL, Salgado MA, Ramalho LM. A preliminary report on the effect of laser therapy on the healing of cutaneous surgical wounds as a consequence of an inversely proportional relationship between wavelength and intensity: histological study in rats. Photomed Laser Surg 2004;22(6):513-8.

Dougherty TJ, Marcus SL. Photodynamic therapy. Eur J Cancer 1992;28A(10):173442.

Dyson M, Young SR. Effect of laser therapy on wound contraction and cellularity in mice. Lasers Med Sci 1986;7:125-30.

Eisen AZ, Holyoke JB, Lobitz WC. Responses of the superficial portion of the human pilosebaceous apparatus to controlled injury. J Invest Dermatol 1955;25:145-56.

Enwemeka CS. Ultrastructural morphometry of membrane bound intracytoplasmatic collagen fibrils in tendon fibroblast exposed to He-Ne laser beam. Tissue Cell 1992;24:511-23.

Erdle BJ, Brouxhon S, Kaplan M, Vanbuskirk J, Pentland AP. Effects of ContinuousWave (670-nm) Red Light on Wound Healing. Dermatol Surg 2008;34:320-5.

Fiddian AP, Yeo JM, Stubbings R, Dean D. Successful treatment of herpes labialis with topical acyclovir. Br Med J (Clin Res Ed) 1983;286:1699-701. 
Fife KH, Barbarash RA, Rudolph T, Degregorio B, Roth R. Valaciclovir versus acyclovir in the treatment of first episode genital herpes infection. Results of an international, multicenter, double-blind, randomized clinical trial. Sex Transm Dis $1997 ; 24: 481$.

Flores ER, Tsai KY, Crowley D, Sengupta S, Yang A, Mckeon F, et al. p63 and p73 are required for p53-dependent apoptosis in response to DNA damage. Nature 2002;416(6880):560-4.

Fork RL. Laser stimulation of nerve cells in aplysia. Science 1971;171:907-8.

Foster TH, Murant RS, Bryant RG, Knox RS, Gibson SL, Hilf R. Oxygen consumption and diffusion effects in photodynamic therapy. Radiat Res 1991;126:296-303.

Franke WW, Schmid E, Freudenstein C, Appelhans B, Osborn M, Weber K, et al. Intermediate-sized filaments of the prekeratin type in myoepithelial cells. J Cell Biol 1980;84:633-54.

Fuchs E, Green $\mathrm{H}$. Changes in keratin gene expression during terminal differentiation of the keratinocyte. Cell 1980;19:1033-42.

Fuchs E, Karakesisoglou I. Bridging cytoskeletal intersections. Genes Dev 2001;15:1-14.

Gál P, Vidinsky B, Toporcer T, Mokry M, Mozes S, Longauer F, et al. Histological Assessment of the Effect of Laser Irradiation on Skin Wound Healing in Rats.

Photomed Laser Surg 2006;24(4):480-8.

Garlick JA. Human skin-equivalent models of epidermal wound healing: Tissue fabrication and biological implications. In: Rovee DT, Maibach HI. The epidermis in wound healing. Boca Raton: CRC Press; 2004. p. 3-23.

Garlick JA, Taichman LB. Fate of human keratinocytes during reepithelialization in an organotypic culture model. Lab Invest 1994;70:916-24.

Genovese WJ. Laser de baixa intensidade. São Paulo: Lovise; 2000. 
Gibbins JR. Epithelial migration in organ culture. A morphological study and time lapse cinematographic analysis of migrating stratified squamous epithelium.

Pathology 1978;10:207-18.

Gibson SL, Vandermeid KR, Murant RS, Raubertas RF, Hilf R. Effects of various photoradiation regimens on the antitumor efficacy of photodynamic therapy for R3230AC mammary carcinomas. Cancer Res 1990;50:7236-41.

Gordon SA, Surrey K. Red and far-red action on oxidative phosphorylation. Radiat Res 1960;12:325-39.

Green KJ, Gaudry CA. Are desmosomes more than tethers for intermediate filaments? Nat Rev Mol Cell Biol 2000;1:208-16.

Grossman N, Schneid N, Reuveni H, Halevy S, Lubart R. 780 nm low power diode laser irradiation stimulates proliferation of keratinocyte cultures: involvement of reactive oxygen species. Lasers Surg Med 1998;22(4):212-8.

Haas AF, Isseroff RR, Wheeland RG, Rood PA, Graves PJ. Low energy helium neon laser irradiation increases the motility of cultured human keratinocytes. J Invest Dermatol 1990;94(6):822-6.

Hamblin MR, Hasan T. Photodynamic therapy: a new antimicrobial approach to infectious disease? Photochem Photobiol Sci 2004;3(5):436-50.

Hamblin MR, O'donnell DA, Murthy N, Contag CH, Hasan T. Rapid control of wound infections by targeted photodynamic therapy monitored by in vivo bioluminescence imaging. Photochem Photobiol 2002;75:51-7.

Hamblin MR, Zahra T, Contag CH, Mcmanus AT, Hasan T. Optical monitoring and treatment of potentially lethalwound infections in vivo. J Infect Dis 2003;187:1717-26.

Hatzfeld M, Haffner C, Schulze K, Vinzens U. The function of plakophilin 1 in desmosome assembly and actin filament organization. J Cell Biol 2000;149:209-22.

Hauschild A, Lischner S, Lange-Asschenfeldt B, Egberts F. Treatment of Actinic Cheilitis Using Photodynamic Therapy with Methylaminolevulinate: Report of Three Cases. Dermatol Surg 2005;31:1344-8. 
Hibi K, Trink B, Patturajan M, Westra WH, Caballero OL, Hill DE, et al. AIS is an oncogene amplified in squamous cell carcinoma. Proc Natl Acad Sci USA 2000;97(10):5462-7.

His RA, Rosenthal DI, Glatstein E. Photodynamic therapy in the treatment of cancer:current state of the art. Drugs 1999;57(5):725-34.

Ho CC, Ho HC, Liu YH, Pei RJ, Cheng CC, Lee KY, et al. Altered synemin could affect the organization of intermediate filament in human hepatocellular carcinoma. $J$ Med 2004;35(1-6):171-80.

Houreld $\mathrm{N}$, Abrahamse $\mathrm{H}$. In vitro exposure of wounded diabetic fibroblast cells to a Helium-Neon laser at 5 and $16 \mathrm{~J} / \mathrm{cm} 2$. Photomed Laser Surg 2007;25(2):78-84.

linuma S, Wagnieres G, Schomacker KT, Bamberg M, Hasan T. The importance of fluence rate in photodynamic therapy with ALA-induced PpIX and BPD-MA in a rat bladder tumor model. In: Dougherty TJ, editor. Optical methods for tumor treatment and detection: mechanisms and techniques in photodynamic therapy IV. Bellingham: SPIE Press; 1995. p. 136-40.

Irvine AD, Mclean WH. Human keratin diseases: the increasing spectrum of disease and subtlety of the phenotype-genotype correlation. Br J Dermatol 1999;140:815-28.

Ishida-Yamamoto A, Takahashi $\mathrm{H}$, Lizuka $\mathrm{H}$. Lessons from disorders of epidermal differentiation-associated keratins. Histol Histopathol 2002;17:331-8.

Izawa I, Nishizawa M, Ohtakara K, Ohtsuka K, Inada H, Inagaki M. Identification of Mrj, a DnaJ/Hsp40 family protein, as a keratin 8/18 filament regulatory protein. J Biol Chem 2000;275:34521-7.

Jackson BW, Grund C, Franke WW, Illmensee K. Formation of cytoskeletal elements during mouse embryogenesis. II. Epithelial differentiation and intermediate filaments in post-implantation embryos of days 5-9. Differentiation 1981;20:203-16.

Jackson BW, Grund C, Schmid E, Bdrki K, Franke WW, Illmensee K. Formation of cytoskeletal elements during mouse embryogenesis. I. Intermediate filaments of the cytokeratin type and desmosomes in preimplantation embryos. Differentiation 1980;77:161-79. 
Jayasree RS, Gupta AK, Rathinam K, Mohanan PV, Mohanty M. The Influence of Photodynamic Therapy on the Wound Healing Process in Rats. J Biomater Appl $2001 ; 15(3): 176-86$.

Jefferis AF, Chevretton EB, Berenbaum MC. Muscle damage and recovery in the rabbit tongue following photodynamic therapy with hematoporphyrin derivative. Acta Otolaryngol 1991;111(1):153-60.

Jensen PKA, Bolund L. Low $\mathrm{Ca}^{2+}$ stripping of differentiation cell layers in human epidermal cultures: an in vitro model of epidermal regeneration. Exp Cell Res 1988;175:63-73.

Jensen PKA, Fey SSJ, Larsen OM, Norgard JOR, Bolund L. Morphological differentiation and changes in polypeptide synthesis pattern regeneration of human epidermal tissue development in vitro. Differentiation 1991;47:37-48.

Jonkman MF, Heeres K, Pas HH, Van Luyn MJ, Elema JD, Corden LD, et al. Effects of keratin 14 ablation on the clinical and cellular phenotype in a kindred with recessive epidermolysis bullosa simplex. J Invest Dermatol 1996;107:764-9.

Jori G, Fabris C, Soncin M, Ferro S, Coppellotti O, Dei D, et al. Photodynamic Therapy in the Treatment of Microbial Infections: Basic Principles and Perspective Applications. Lasers Surg Med 2006;38:468-81.

Kalinin A, Marekov LN, Steinert PM. Assembly of the epidermal cornified cell envelope. J Cell Sci 2001;114:3069-70.

Kallioinen M, Koivukangas V, Jarvinen M, Oikarinen A. Expression of cytokeratins in regenerating human epidermis. Br J Dermatol 1995;133:830-5.

Kana JS, Hutschenreiter G, Haina D, Waidelich W. Effect of lowpower density laser radiation on healing of open skin wounds in rats. Arch Surg 1981;116:293-6.

Karu TI. Effects of visible radiation on cultured cells. J Photochem. Photobiol. 1990;52:1089-1098.

Karu TI. Photobiology of low-power laser effects. Health Phys 1989;56(5):691-704. 
Karu TI. Photobiological fundamentals of low power laser therapy. IEEE J Quant Elect 1987;23:1703.

Karu TI, Andreichuk T, Ryabykh T. Changes in oxidative metabolism of murine spleen following laser and superluminous diode $(660-950 \mathrm{~nm})$ irradiation: Effects on cellular composition and radiation parameters. Lasers Surg Med 1993;13:453-62.

Karu TI, Pyatibrat L, Kalendo G. Irradiation with He-Ne laser increases ATP level in cells cultivated in vitro. J Photochem Photobiol B 1995;27(3):219-23.

Karu TI, Pyatibrat L, Kalendo G, Esenaliev R. Effects of monochromatic low-intensity light and laser irradiation on adhesion of HeLa cells in vitro. Lasers Surg Med 1996;18:171-7.

Karu TI, Pyatibrat L, Ryabykh T. Nonmonotonic behavior of the dose dependence of the radiation effect on cells in vitro exposed to pulsed laser radiation at $14820 \mathrm{~nm}$. Lasers Surg Med 1997;21:485-92.

Kato K, Shinzawa K, Yoshikawa S. Cytochrome oxidase is a possible photoreceptor in mitochondria. Photobiochem Photobiophys 1981;2:263-9.

Kaufman J. Do lasers have a role in wound healing? Dermatol Times 2006;November:58-9.

Kirsner R. Wound healing. In: Bolognia J, Jorizzo J, Rapini R, editors. Dermatology. Bolognia: Mosby; 2003. p. 2207-18.

Koster MI, Dai D, Marinari B, Sano Y, Costanzo A, Karin M, et al. p63 induces key target genes required for epidermal morphogenesis. PNAS 2007;104(9):3255-60.

Koster MI, Kim S, Mills AA, DeMayo FJ, Roop DR. p63 is the molecular switch for the initiation of an epithelial stratification program. Genes Dev 2004;18(2):126-31.

Koster MI, Roop DR. The role of p63 in development and differentiation of the epidermis. J Dermatol Sci 2004;34:3-9.

Krawczyk WS. A pattern of epidermal cell migration during wound healing. J Cell Biol 1971;49:247-63. 
Krawczyk WS. Some ultrastructural aspects of epidermal repair in two model wound healing systems. In: Maibach HI, Rovee DT, editors. Epidermal wound healing. Chicago: Year Book Medical; 1972. p. 123-31.

Kreisler M, Christoffers AB, Willershausen B, d'Hoedt B. Effect of low-level GaAlAs laser irradiation on the proliferation rate of human periodontal ligament fibroblasts: an in vitro study. J Clin Periodontol 2003;30:353-8.

Krepler R, Denk H, Weirich E, Schmid E, Franke WW. Keratin-like proteins in normal and neoplastic cells of human and rat mammary gland as revealed by immunofluorescence microscopy. Differentiation 1981;20:242-52.

Ku NO, Liao J, Omary MB. Phosphorylation of human keratin 18 serine 33 regulates binding to 14-3-3 proteins. EMBO J 1998;17:1892-906.

Ku NO, Zhou X, Toivola DM, Omary MB. The cytoskeleton of digestive epithelia in health and disease. Am J Physiol 1999;277:1108-37.

Kübler A, Finley RK, Born IA, Mang TS. Effect of photodynamic therapy on the healing of a rat skin flap and its implication for head and neck reconstructive surgery. Lasers Surg Med 1996;18(4):397-405.

Kurokawa I, Mizutani H, Kusumoto K. Cytokeratin, filaggrin, and p63 expression in reepithelialization during human cutaneous wound healing. Wound Rep Reg 2006;14:38-45.

Kurokawa I, Nishijima S, Kusumoto K, Senzaki H, Shikata N, Tsubura A. Trichilemmoma: an immunohistochemical study of cytokeratins. $\mathrm{Br} \mathrm{J}$ Dermatol 2003;149:99-104.

Lagan KM, Clements BA, McDonough S, Baxter GD. Low intensity laser therapy $(830 \mathrm{~nm})$ in the management of minor postsurgical wounds: a controlled clinical study. Lasers Surg Med 2001;28:27-32.

Lambrechts SA, Demidova TN, Aalders MC, Hasan T, Hamblin MR. Photodynamic therapy for Staphylococcus aureus infected burn wounds in mice. Photochem Photobiol Sci 2005;4(7):503-9. 
Langbein L, Rogers MA, Winter H, Praetzel S, Beckhaus U, Rackwitz HR, et al. The catalog of human hair keratins I. Expression of the nine type I members in the hair follicle. J Biol Chem 1999;274(28):19874-84.

Laplante AF, Germain L, Auger FA, Moulin V. Mechanisms of wound reepithelialization: hints from a tissue-engineered reconstructed skin to long-standing questions. Faseb J 2001;15:2377-89.

Larderet G, Fortunel NO, Vaigot P, Cegalerba M, Maltere P, Zobiri O, et al. Human side population keratinocytes exhibit long-term proliferative potential and a specific gene expression profile and can form a pluristratified epidermis. Stem Cells 2006;24(4):965-74.

Laurikkala J, Mikkola ML, James M, Tummers M, Mills AA, Thesleff I. p63 regulates multiple signalling pathways required for ectodermal organogenesis and differentiation. Development 2006;133:1553-63.

Liefer KM, Koster MI, Wang XJ, Yang A, McKeon F, Roop DR. Down-regulation of p63 is required for epidermal UV-B-induced apoptosis. Cancer Res 2000;60:4016-20.

Liovic M, Stojan J, Bowden PE, Gibbs D, Vahlquist A, Lane EB, et al. A novel keratin 5 mutation (K5V186L) in a family with EBS-K: a conservative substitution can lead to development of different disease phenotypes. J Invest Dermatol 2001;116:964-9.

Lisnjak IO, Kutsenok VV, Polyschuk LZ, Gorobets OB, Gamaleia NF. Effect of photodynamic therapy on tumor angiogenesis and metastasis in mice bearing Lewis lung carcinoma. Exp Oncol 2005;27(4):333-5.

Liu YH, Cheng CC, Ho CC, Pei RJ, Lee KY, Yeh KT, et al. Effects of diode $808 \mathrm{~nm}$ GaAIAS low-power laser irradiation on inhibition the proliferation of human hepatoma cells in vitro and their possible mechanism. Res Commun Mol Pathol Pharmacol 2004;115-116:185-201.

Liu YH, Ho CC, Cheng CC, Hsu YH, Lai YS. Photoradiation could influence the cytoskeleton organization and inhibit the survival of human hepatoma cells in vitro. Lasers Med Sci 2006;21(1):42-8.

Lloyd C, Yu QC, Cheng J, Turksen K, Degenstein L, Hutton E, et al. The basal keratin network of stratified squamous epithelia: defining $\mathrm{K} 15$ function in the absence of K14. J Cell Biol 1995;129:1329-44. 
Lobitz C, Holyoke JB, Montagna W. Responses of the human eccrine sweat duct to controlled injury. J Invest Dermatol 1954;23:329-44.

Loevschall $\mathrm{H}$, Arenholt-Bindslev D. Effect of low level diode laser irradiation of human oral mucosa fibroblasts in vitro. Lasers Surg Med 1994;14:347-54.

Lopes LA, Rigau J, Zangaro RA. Comparison of the low level laser therapy effects on cultured human gingival fibroblast proliferation using different irradiance and some fluence. Laser Surg Med 2001; 29:179-84.

Lou PJ, Jager HR, Jones L, Theodossy T, Bown SG, Hopper C. Interstitial photodynamic therapy as salvage treatment for recurrent head and neck cancer. $\mathrm{Br} \mathrm{J}$ Cancer 2004;91(3):441-6.

Lubart R, Friedmann $\mathrm{H}$, Lavie R. Photobiostimulation as a function of different wavelengths. Laser Therapy 1999;12:38-41.

Lubart R, Friedmann H, Sinyakov M, Cohen N, Breitbart H. Changes in calcium transport in mammalian sperm mitochondria and plasma membranes caused by 780n irradiation. Lasers Surg Med 1997;21:493-9.

Lundeberg T, Malm M. Low-power HeNe laser treatment of venous leg ulcers. Ann Plast Surg 1991;27:537-9.

Lyons RF, Abergel RP, White RA, Dwyer RM, Castel JC, Uitto J. Biostimulation of wound healing in vivo by a helium-neon laser. Ann Plast Surg 1987;18:47-50.

Mansbridge JN, Knapp AM. Changes in keratinocyte maturation during wound healing. J Invest Dermatol 1987;89:253-63.

Martin P. Wound healing-aiming for perfect skin regeneration. Science 1997;276:7581.

Martinez I. Fine structure studies of migrating epithelial cells. In: Maibach $\mathrm{H}$, Rovee D, editors. Epidermal wound healing. Chicago: Year Book Medical; 1972. p. 323-42.

Mashiko S, Shimamoto, Inaba $\mathrm{H}$. Effect of near infra-red light irradiation on wound healing using high power light emitting diodes. J Jpn Soc Laser 1983;4:187-92. 
Medrado AR, Pugliese LS, Reis SR, Andrade ZA. Influence of low level laser therapy on wound healing and its biological action upon myofibroblasts. Lasers Surg Med 2003;32:239-44.

Mester E, Korenyi-Both A, Spiry T, Tisza S. The effect of laser irradiation on the regeneration of muscle fibers (preliminary report). Z Exp Chirurg 1975;8:258-62.

Mester E, Mester AF, Mester A. The biomedical effects of laser application. Lasers Surg Med 1985;5:31-9.

Mester E, Spiry T, Szende B, Tota JG. Effect of laser rays on wound healing. Am J Surg 1971;122:532-5.

Mills AA, Zheng B, Wang XJ, Vogel H, Roop DR, Bradley A. p63 is a p53 homologue required for limb and epidermal morphogenesis. Nature 1999;398(6729):708-13.

Moll R, Franke WW, Schiller DL, Geiger B, Krepler R. The catalog of human cytokeratins: patterns of expression in normal epithelia, tumors and cultured cells. Cell 1982a;31:11-24.

Moll R, Franke WW, Volc-Platzer B, Krepler R. Different keratin polypeptides in epidermis and other epithelia of human skin: a specific cytokeratin of molecular weight 46,000 in epithelia of the pilosebaceous tract and basal cell epitheliomas. J Cell Biol 1982b;95(1):285-95.

Moll R, Krepler R, Franke WW. Complex cytokeratin polypeptide patterns observed in diverse human carcinomas. Differentiation 1983;23(3):256-69.

Morris RJ, Liu Y, Marles L, Yang Z, Trempus C, Li S, et al. Capturing and profiling adult hair follicle stem cells. Nat Biotechnol 2004;22:411-7.

Morton CA, Brown SB, Collins S, Ibbotson S, Jenkinson H, Kurwa H, et al. Guidelines for topical photodynamic therapy: report of a workshop of the British

Photodermatology Group. Br J Dermatol 2002;146(4):552-67.

Munz B, Wiedmann M, Lochmuller H, Werner S. Cloning of novel injury-regulated genes. Implications for an important role of the muscle-specific protein skNAC in muscle repair. J Biol Chem 1999;274:13305-10. 
Nelson WG, Sun TT. The 50- and 58-kdalton keratin classes as molecular markers for stratified squamous epithelia: cell culture studies. J Cell Biol 1983;97:244-51.

Noble PB, Shields ED, Blecher PD, Bentley KC. Locomotory characteristics of fibroblasts within a three-dimensional collagen lattice: modulation by a helium/neon soft laser. Lasers Surg Med 1992;12:669-74.

Noszczyk BH, Majewski ST. p63 expression during normal cutaneous wound healing in humans. Plast Reconstr Surg 2001;108(5):1242-7; discussion 1248-50.

Odland G, Ross R. Human wound repair. I. epidermal regeneration. J Cell Biol 1968;39:135-51.

Ohyama M, Terunuma A, Tock CL, Radonovich MF, Pise-Masison CA, Hopping SB, et al. Characterization and isolation of stem cell-enriched human hair follicle bulge cells. J Clin Invest 2006;116(1):249-60.

Okada Y, Osada M, Kurata S, Sato S, Aisaki K, Kageyama Y, et al. p53 gene family p51(p63)-encoded, secondary transactivator p51B(TAp63alpha) occurs without forming an immunoprecipitable complex with MDM2, but responds to genotoxic stress by accumulation. Exp Cell Res 2002;276(2):194-200.

Olive M, Goldfarb L, Dagvadorj A, Sambuuhin N, Paulin D, Li Z, et al. Expression of the intermediate filament protein synemin in myofibrillar myopathies and other muscle diseases. Acta Neuropathol 2003;106:1-7.

Omary MB, Ku N-O, Liao J, Price D. Keratin modifications and solubility properties in epithelial cells and in vitro. In: Herrman H, Harris JR. Subcellular biochemistry: intermediate filaments. New York: Plenum Press; 1998. p. 105-40.

Originali L. Risultati clinici di stimulazione laser I studi sperimentali circa il macanismo di azione. Min Méd 1981;72:2195-9.

Orringer JS, Hammerberg C, Hamilton T, Johnson TM, Kang S, Sachs DL, et al. Molecular effects of photodynamic therapy for photoaging. Arch Dermatol 2008 Oct;144(10):1296-302.

Ortonne JP, Loning T, Schmitt D, Thivolet J. Immunomorphological and ultrastructural aspects of keratinocyte migration in epidermal wound healing. Virchows Arch A Pathol Anat Histol 1981;392:217-30. 
Osada M, Ohba M, Kawahara C, Ishioka C, Kanamaru R, Katoh I, et al. Cloning and functional analysis of human p51, which structurally and functionally resembles p53. Nat Med1998;4:839-43.

Oshima H, Rochat A, Kedzia C, Kobayashi K, Barrandon Y. Morphogenesis and renewal of hair follicles from adult multipotent stem cells. Cell 2001;104:233-45.

Pang SC, Daniels WH, Buck RC. Epidermal migration during the healing of suction blisters in rat skin: a scanning and transmission electron microscopic study. Am J Anat 1978;153:177-91.

Parekh SG, Trauner KB, Zarins B, Foster TE, Anderson RR. Photodynamic Modulation of Wound Healing With BPD-MA and CASP. Lasers Surg Med 1999;24:375-81.

Park BJ, Lee SJ, Kim JI, Lee CH, Chang SG, Park JH, et al. Frequent alteration of p63 expression in human primary bladder carcinomas. Cancer Res 2000;60(13):3370-4.

Parsa R, Yang A, McKeon F, Green H. Association of p63 with proliferative potential in normal and neoplastic human keratinocytes. J Invest Dermatol 1999;113:1099.

Passarella S, Casamassima F, Molinari S, Pastore D, Quagliariello E, Catalano IM, et al. Increase of proton eletrochemical potential and ATP synthesis in rat liver mitochondria irradiated in vitro by He-Ne laser. FEBS Lett 1984;175:95-9.

Pastore D, Greco M, Passarella S. Specific helium-neon laser sensitivity of the purified cytochrome c oxidase. Int J Radiat Biol 2000;76:863-70.

Patturajan M, Nomoto S, Sommer M, Fomenkov A, Hibi K, Zangen R, et al. DeltaNp63 induces beta-catenin nuclear accumulation and signaling. Cancer Cell 2002;1(4):369-79.

Pellegrini G, Dellambra E, Golisano O, Martinelli E, Fantozzi I, Bondanza S, et al. p63 identifies keratinocyte stem cells. Proc Natl Acad Sci USA 2001;98:315661.

Peng Q, Berg K, Moan J, Kongshaug M, Nesland JM. 5-Aminolevulinic acid-based photodynamic therapy: principles and experimental research. Photochem Photobiol 1997;65(2):235-51. 
Pereira AN, Eduardo CP, Matson E, Marques MM. Effect of low-power laser irradiation on cell growth and procollagen synthesis of cultured fibroblasts. Lasers Surg Med 2002;31:263-7.

Pessoa ES, Melhado RM, Theodoro LH, Garcia VG. A Histologic Assessment of the Influence of Low-Intensity Laser Therapy on Wound Healing in Steroid-Treated Animals. Photomed Laser Surg 2004;22(3):199-204.

Peters B, Kirfel J, Bussow H, Vidal M, Magin TM: Complete cytolysis and neonatal lethality in keratin 5 knockout mice reveal its fundamental role in skin integrity and in epidermolysis bullosa simplex. Mol Biol Cell 2001;12:1775-89.

Pinheiro ALB. Interação tecidual-lasers cirúrgicos. São Paulo: Pancast; 1998.

Pinheiro ALB, Carneiro NS, Vieira AL, Brugnera A Jr, Zanin FA, Barros RA, et al. Effects of low-level laser therapy on malignant cells: in vitro study. J Clin Laser Med Surg 2002;20(1):23-6.

Pinheiro ALB, Meireles GCS, Barros-Vieira AL, Almeida D, Carvalho CM, Santos JN. Phototherapy improves healing of cutaneous wounds in nourished and undernourished Wistar rats. Braz Dent J 2004;15:21-8.

Pinheiro ALB, Meireles GCS, Carvalho CM, Vieira ALB, Santos JN, Ramalho LMP. Biomodulative effects of polarized light on the healing of cutaneous wounds on nourished and undernourished Wistar rats. Photomed Laser Surg 2006;24:616-24.

Pollack SV. Wound healing: a review. I. The biology of wound healing. J Dermatol Surg Oncol 1979;5:389-93.

Posten W, Wrone DA, Dover JS, Arndt KA, Silapunt S, Alam M. Low-level laser therapy for wound healing: mechanism and efficacy. Dermatol Surg 2005;31(3):33440.

Pugliese LS, Medrado AP, Reis SRA, Andrade ZA. THE influence of low-laser therapy on biomodulation of collagen and elastic fibers. Pesq Odontol Bras 2003;17:307-13. 
Raborn GW, Martel AY, Lassonde M, Lewis MA, Boon R, Spruance SL. Worldwide Topical Penciclovir Collaborative Study Group. Effective treatment of herpes simplex labialis with penciclovir cream: combined results of two trials. J Am Dent Assoc 2002;133:303-9.

Radice GP. The spreading of epithelial cells during wound closure in Xenopus larvae. Dev Biol 1980;76:26-46.

Ratovitski EA, Patturajan M, Hibi K, Trink B, Yamaguchi K, Sidransky D. p53 associates with and targets DNp63 into a protein degradation pathway. Proc Natl Acad Sci USA 2001;98:1817-22.

Read J, Watt FM. A model for in vitro studies of epidermal homeostasis: proliferation and involucrin synthesis by cultured human keratynocites during recovery after stripping off the suprabasal layers. J Invest Dermatol 1988;90:739-43.

Reichelt J, Bussow H, Grund C, Magin TM. Formation of a normal epidermis supported by increased stability of keratins 5 and 14 in keratin 10 null mice. Mol Biol Cell 2001;12:1557-68.

Reis SRA, Medrado AP, Marchionni AMT, Figueira C, Fracassi LD, Knop LAH. Effect of 670-nm Laser Therapy and Dexamethasone on Tissue Repair: A Histological and Ultrastructural Study. Photomed Laser Surg 2008;26(4):307-13.

Reis-Filho JS, Simpson PT, Martins A, Preto A, Gärtner F, Schmitt FC. Distribution of p63, cytokeratins 5/6 and cytokeratin 14 in 51 normal and 400 neoplastic human tissue samples using TARP-4 multi-tumor tissue microarray. Virchows Arch 2003;443(2):122-32.

Reis-Filho JS, Torio B, Albergaria A, Schmitt FC. p63 expression in normal skin and usual cutaneous carcinomas. J Cutan Pathol 2002;29:517-23.

Ribeiro MAG, Albuquerque RLC, Ramalho LMP, Pinheiro ALB, Bonjardim LR, Da Cunha SS. Immunohistochemical assessment of myofibroblasts and lymphoid cells during wound healing in rats subjected to laser photobiomodulation at $660 \mathrm{~nm}$. Photomed Laser Surg 2009;27(1):49-55.

Ribeiro MS, Zezzel DM. Laser de baixa intensidade. In: Gutknecht N, Eduardo CP. A odontologia e o laser: atuação do laser na especialidade odontológica. São Paulo: Quintessence; 2004. cap. 5, p. 217-40. 
Rigau I. Acción de la luz laser a baja intensidad en la modulación de la función celular [M.D. dissertation]. Universitat Rovira i Virgili; 1996.

Rochkind S, Rousso M, Nissan M, Villarreal M, Barr-Nea L, Rees DG. Systemic effects of low power laser irradiation on the peripheral and central nervous system, cutaneous wounds and burns. Lasers Surg Med 1989;9(2):174-82.

Rood PA, Haas AF, Graves PJ, Wheeland RG, Isseroff RR. Low-energy helium neon laser irradiation does not alter human keratinocyte differentiation. J Invest Dermatol 1992;99(4):445-8.

Ross JI, Snelling AM, Carnegie E, Coates P, Cunliffe WJ, Bettoli V, et al. Antibioticresistant acne: lessons from Europe. Br J Dermatol 2003;148(3):467-78.

Saccone C, Barome PO, D'Erchia AM, D'Errico I, Pessole G, Sbisà E, et al. Molecular strategies in Metazoan genomic evolution. Gene 2002;300(1-2):195-201.

Saltmarche AE. Low level laser therapy for healing acute and chronic wounds - the extendicare experience. Int Wound J 2008;5:351-60.

Sasaki Y, Ishida S, Morimoto I, Yamashita T, Kojima T, Kihara C, et al. The p53 family member genes are involved in the Notch signal pathway. J Biol Chem $2001 ; 277(1): 719-24$.

Schindl A, Schindl M, Schindl L. Successful treatment of a persistent radiation ulcer by low power laser therapy. J Am Acad Dermatol 1997;37:646-8.

Schindl A, Schindl M, Schön H, Knobler R, Havelec L, Schindl L. Low-intensity laser irradiation improves skin circulation in patients with diabetic microangiopathy.

Diabetes Care 1998;21(4):580-4.

Schlager A, Kronberger P, Petschke F, Ulmer H. Low-power laser light in the healing of burns: a comparison between two different wavelengths $(635 \mathrm{~nm}$ and $690 \mathrm{~nm})$ and a placebo group. Lasers Surg Med 2000a;27:39-42.

Schlager A, Oehler K, Huebner KU, Schmuth M, Spoetl L. Healing of burns after treatment with 670-nanometer low-power laser light. Plast Reconstr Surg 2000b;105(5):1635-9. 
Schultz EW, Krueger AP. Inactivation of Staphylococcus bacteriophage by methylene blue. Proc Soc Exp Biol Med 1928;26:100-1.

Sciubba JJ. Regeneration of the basal lamina complex during epithelial wound healing. J Periodontal Res 1977;12:204-17.

Shi J, Sugrue SP. Dissection of protein linkage between keratins and pinin, a protein with dual location at desmosomeintermediate filament complex and in the nucleus. J Biol Chem 2000;275:14910-5.

Shu B, Wu Z, Hao L, Zeng D, Feng G, Lin Y. Experimental study on He-Ne laser irradiation to inhibit scar fibroblast growth in culture. Chin J Traumatol 2002;5(4):2469.

Silva JC, Lacava ZG, Kuckelhaus S, Silva LP, Neto LF, Sauro EE, et al. Evaluation of the Use of Low Level Laser and Photosensitizer Drugs in Healing. Lasers Surg Med 2004;34(5):451-7.

Silveira PCL, Streck EL, Pinho RA. Evaluation of mitochondrial respiratory chain activity in wound healing by low-level laser therapy. J Photochem Photobiol B: Biology 2007;86:279-82.

Singer A, Clark RA. Cutaneous wound healing. N Eng J Med 1999;341:738-46.

Sitnik TM, Hampton JA, Henderson BW. Reduction of tumor oxygenation during and after photodynamic therapy in vivo: effects of fluence rate. $\mathrm{Br} \mathrm{J}$ Cancer 1998;77(9):1386-94.

Sitnik TM, Henderson BW. The Effect of Fluence Rate on Tumor and Normal Tissue Responses to Photodynamic Therapy. Photochem Photobiol 1998;67(4):462-6.

Smetana Z, Malik Z, Orenstein A, Mendelson E, Ben-Hur E. Treatment of viral infections with 5-aminolevulinic acid and light. Lasers Surg Med 1997;21(4):351-8.

Smith FJD. The molecular genetics of keratin disorders. Am J Clin Dermatol 2003;4:347-64.

Smith KL, Dean SJ. Tissue repair of the epidermis and dermis. J Hand Ther 1998;11:95-104. 
Sobanko JF, Alster TS. Efficacy of Low-Level Laser Therapy for Chronic Cutaneous Ulceration in Humans: A Review and Discussion. Dermatol Surg 2008;34:991-1000.

Spanheimer RG. Direct inhibition of collagen production in vitro by diabetic rats serum. Metabolism 1988;37:479-85.

Sperandio FF, Marotti J, Aranha ACC, Eduardo CP. Photodynamic therapy for recurrent herpes labialis - Early preliminary results. Gen Dent 2009. No prelo.

Spruance SL, Rea TL, Thoming C, Tucker R, Saltzman R, Boon R. Penciclovir cream for the treatment of herpes simplex labialis: a randomized, multicenter, doubleblind, placebo controlled trial. Topical penciclovir collaborative study group. J Am Med Assoc 1997;277(17):1374-9.

Stadler I, Lanzafame RJ, Evans R, Narayan V, Dailey B, Buehner N. 830-nm irradiation increases the wound tensile strength in a diabetic murine model. Lasers Surg Med 2001;28(3):220-6.

Statius van Eps RG, Adili F, Watkins MT, Anderson RR, LaMuraglia GM. Photodynamic therapy of extracellular matrix stimulates endothelial cell growth by inactivation of matrix-associated transforming growth factor-beta. Lab Invest 1997;76(2):257-66.

Steinbock FA, Nikolic B, Coulombe PA, Fuchs E, Traub P, Wiche G. Dose-dependent linkage, assembly inhibition and disassembly of vimentin and cytokeratin 5/14 filaments through plectin's intermediate filament-binding domain. J Cell Sci 2000;113:483-91.

Steinert PM, Marekov LN. The proteins elafin, filaggrin, keratin intermediate filaments, loricrin, and small proline-rich proteins 1 and 2 are isodipeptide crosslinked components of the human epidermal cornified cell envelope. J Biol Chem 1995;270:17702-11.

Stenn KS, dePalma L. Re-epithelialization. In: Clark RAF, Henson PM, editors. The molecular and cellular biology of wound repair. New York: Plenum Press; 1988. p. 321-35.

Stenn KS, Malhotra R. Epithelialization. In: Cohen IK, Diegelmann RF, Lindblad WJ, editors. Wound healing: biochemical and clinical aspects. Philadelphia: WB Saunders; 1992. p. 15-27. 
Stern SJ, Thomsen S, Small S, Jacques S. Photodynamic therapy with chloroaluminium-sulfonated phthalocyanine. Arch Octolaryngol Head Neck Surg 1990;116(11):1259-66.

Steven AC, Steinert PM. Protein composition of cornified cell envelopes of epidermal keratinocytes. J Cell Sci 1994;107:693-700.

Svitkina TM, Verkhovsky AB, Borisy GG. Plectin sidearms mediate interaction of intermediate filaments with microtubules and other components of cytoskeleton. $\mathrm{J}$ Cell Biol 1996;135:991-1007.

Szeimies RM, Karrer S, Radakovic-Fijan S, Tanew A, Calzavara-Pinton PG, Zane C, et al. Photodynamic therapy using topical methyl 5-aminolevulinate compared with cryotherapy for actinic keratosis: a prospective, randomized study. J Am Acad Dermatol 2002;47(2):258-62.

Tsujita-Kyutoku M, Kiuchi K, Danbara N, Yuri T, Senzaki H, Tsubura A. p63 expression in normal human epidermis and epidermal appendages and their tumors. J Cutan Pathol 2003;30:11-7.

Tumbar T, Guasch G, Greco V, Blanpain C, Lowry WE, Rendl M, et al. Definig the epithelial stem cell niche in skin. Science 2004;303(5656):359-63.

Tunér J, Hode L. Laser therapy in dentistry and medicine. Edsbruk: Prima Books; 1996.

Usui ML, Mansbridge JN, Carter WG, Fujita M, Olerud JE. Keratinocyte Migration, Proliferation, and Differentiation in Chronic Ulcers From Patients With Diabetes and Normal Wounds. J Histochem Cytochem 2008;56(7):687-96.

Usui ML, Underwood RA, Mansbridge JN, Muffley LA, Carter WG, Olerud JE. Morphological evidence for the role of suprabasal keratinocytes in wound reepithelialization. Wound Rep Reg 2005;13(5):468-79.

Van Boxem AJM, Westerga J, Venmans BJW, Postmus PE, Sutedja G. Photodynamic therapy, Nd-YAG laser and electrocautery for treating early-stage intraluminal cancer: which to choose? Lung Cancer 2001;31:31-6. 
Van Geel IP, Oppelaar H, Marijnissen JP, Stewart FA. Influence of fractionation and fluence rate in photodynamic therapy with Photofrin or mTHPC. Radiat Res 1996;145(5):602-9.

Vaughan RB, Trinkaus JP. Movements of epithelial cell sheets in vitro. J Cell Sci 1966;1:407-13.

Vekshin NL, Mironov GP. Flavin-dependent oxygen uptake in mitochondria under illumination. Biofizika 1982;27:537-9.

Viegas VN, Abreu MER, Viezzer C, Machado DC, Filho MS, Silva DN, et al. Effect of Low-Level Laser Therapy on Inflammatory Reactions during Wound Healing:

Comparison with Meloxicam. Photomed Laser Surg 2007;25(6):467-73.

Viegas VN, Prietto L, Mezzomo LA, Abreu MER, Pagnoncelli RM. Controle do edema: Terapia medicamentosa x Uso do laser. Rev Assoc Bras Odontol 2005;13:245-50.

Walker RA. Quantification of immunohistochemistry-issues concerning methods, utility and semiquantitative assesment I. Histochemistry 2006;49:406-10.

Walsh LJ. The current status of low-level laser therapy in dentistry. Soft tissue applications. Aus Dent J 1997;42(Pt 1):247-54.

Watanabe S, Osumi M, Ohnishi T, Ichikawa E, Takahashi H. Changes in cytokeratin expression in epidermal keratinocytes during wound healing. Histochemistry 1995;103:425-33.

Watt FM. The stem cell compartment in human interfollicular epidermis. J Dermatol Sci 2002;28:173-80.

Weber A, Bellmann U, Bootz F, Wittekind C, Tannapfel A. Expression of p53 and its homologues in primary and recurrent squamous cell carcinomas of the head and neck. Int J Cancer 2002;99:22-8.

Whelan HT, Smits RL Jr, Buchman EV, Whelan NT, Turner SG, Margolis DA, et al. Effect of NASA light-emitting diode irradiation on wound healing. J Clin Laser Med Surg 2001;19(6):305-14. 
Wiche G. Role of plectin in cytoskeleton organization and dynamics. J Cell Sci 1998;111:2477-86.

Wilden L, Kerthein R. Import of radiation phenomena of electrons and therapeutic low-level laser in regard to the mitochondrial energy transfer. J Clin Laser Med Surg 1998;16(3):159-65.

Wilson M, Dobson J, Harvey W. Sensitization of oral bacteria to killing by low-power laser radiation. Curr Microbiol 1992;25(2):77-81.

Winter GD. Epidermal regeneration studies in the domestic pig. In: Maibach HI, Rovec DT, editors. Epidermal wound healing. Chicago: Year Book Medical; 1972. p. 71-112.

Wong-Riley MT, Bai X, Buchmann E, Whelan HT. Lightemitting diode treatment reverses the effect of TTX on cytochrome oxidase in neurons. NeuroReport 2001;12:3033-7.

Wong-Riley MT, Liang HL, Eells JT, Chance B, Henry MM, Buchmann E, et al. Photobiomodulation directly benefits primary neurons functionally inactivated by toxins: role of cytochrome c oxidase. J Biol Chem 2005;280:4761-71.

Woodley DT. Reepithelialization. In: Clark RAF, editor. The molecular and cellular biology of wound repair. New York: Plenum Press; 1996. p. 339-54.

Woodley DT, O'Toole EO, Nadelman CM, Li W. Mechanisms of human keratinocyte migration: lessons for understanding the re-epithelialization of human skin wounds. Dermatol Found 1999;33:1-12.

Wyatt TD, Ferguson WP, Wilson TS, McCormick E. Gentamicin resistant Staphylococcus aureus associated with the use of topical gentamicin. J Antimicrob Chemother 1977;3(3):213-7.

Yamaguchi K, Wu L, Caballero OL, Hibi K, Trink B, Resto V, et al. Frequent gain of the p40/p51/p63 gene locus in primary head and neck squamous cell carcinoma. Int J Cancer 2000;86(5):684-9.

Yang A, Kaghad M, Caput D, McKeon F. On the shoulders of giants: p63, p73 and the rise of p53. Trends Genet 2002;18:90-5. 
Yang A, Kaghad M, Wang Y, Gillet E, Fleming M, Dotsch V, et al. p63, a p53 homolog at 3q27-29, encodes multiple products with transactivating, death-inducing, and dominant-negative activities. Mol Cell 1998;2:305-16.

Yang A, Schweitzer R, Sun D, Kaghad M, Walker N, Bronson RT, et al. p63 is essential for regenerative proliferation in limb, craniofacial and epithelial development. Nature 1999;398(6729):714-8.

Yang TH, Chen CT, Wang CP, Lou PJ. Photodynamic therapy suppresses the migration and invasion of head and neck cancer cells in vitro. Oral Oncology 2007:43:358-65.

Zhang XJ, Chinkes DL, Cox RA, Wolfe RR. The Flow Phase of Wound Metabolism Is Characterized by Stimulated Protein Synthesis Rather Than Cell Proliferation. J Surg Res 2006;135(1):61-7. 
ANEXO A - Parecer do Comitê de Ética em Pesquisa

\author{
UNIVERSIDADE DE SÃO PAULO \\ FACULDADE DE ODONTOLOGIA
}

\author{
PARECER DE APROVAÇÃO \\ PROTOCOLO ${ }^{\circ} 11 / 08$
}

Com base em parecer de relator, o Comitê de Ética em Pesquisa - Subcomissão de Bioética de Animais da Faculdade de Odontologia da Universidade de São Paulo, APROVOU o protocolo de pesquisa "Avaliação da reparação tecidual de excisões realizadas em dorso de ratos e submetidos à terapia foto-dinâmica com utilização de corante azul de metileno", de responsabilidade do(a) pesquisador(a) Felipe Fornias Sperandiio sob orientação do(a) Prof(a). Dr(a). Suzana Orsini Cantanhede Machado de Sousa.

Cabe ao responsável enviar relatórios referentes ao andamento da pesquisa após 06 (seis) meses e 01 (um) ano desta data, bem como cópia do trabalho em "cd" ou "disquete" ao finalizá-lo, conforme legislação vigente.

Săo Paulo, 26 de novembro de 2008

Prof. Dr. Celso Luiz Caldeira

PRESIDENTE DA SUBCOMISSÄ́O DE BIOÉTICA DE ANIMAIS DA FOUSP 
ANEXO B - Teste de Kruskal Wallis. Os números em vermelho representam diferenças estatisticamente significantes

\begin{tabular}{|c|c|c|c|c|c|c|c|}
\hline Variável & Grupo & $\mathrm{n}$ & Média & Desvio-padrão & Mínimo & Máximo & Significância (p) \\
\hline \multirow{5}{*}{ Área Inicial } & Controle & 5 & 33,21 & 4,91 & 25,87 & 39,62 & \multirow{4}{*}{0,182} \\
\hline & Corante & 5 & 28,15 & 8,16 & 19,00 & 39,27 & \\
\hline & Laser & 5 & 24,60 & 3,48 & 19,42 & 28,44 & \\
\hline & PDT & 5 & 29,80 & 9,55 & 16,66 & 43,63 & \\
\hline & Total & 20 & 28,94 & 7,14 & 16,66 & 43,63 & \\
\hline \multirow{5}{*}{ Perímetro Inicial } & Controle & 5 & 22,31 & 1,96 & 19,51 & 25,06 & \multirow{4}{*}{0,142} \\
\hline & Corante & 5 & 20,83 & 2,31 & 18,90 & 24,19 & \\
\hline & Laser & 5 & 18,98 & 1,36 & 16,85 & 20,27 & \\
\hline & PDT & 5 & 21,08 & 3,15 & 16,52 & 25,39 & \\
\hline & Total & 20 & 20,80 & 2,43 & 16,52 & 25,39 & \\
\hline \multirow{5}{*}{$\begin{array}{l}\text { Fator de Forma } \\
\text { Inicial }\end{array}$} & Controle & 5 & 0,83 & 0,02 & 0,79 & 0,85 & \multirow{4}{*}{0,179} \\
\hline & Corante & 5 & 0,79 & 0,08 & 0,66 & 0,84 & \\
\hline & Laser & 5 & 0,85 & 0,01 & 0,83 & 0,86 & \\
\hline & PDT & 5 & 0,81 & 0,03 & 0,76 & 0,85 & \\
\hline & Total & 20 & 0,82 & 0,05 & 0,66 & 0,86 & \\
\hline \multirow{5}{*}{ Área 24h } & Controle & 5 & 24,86 & 6,19 & 15,04 & 31,84 & \multirow{4}{*}{0,138} \\
\hline & Corante & 5 & 24,37 & 2,73 & 21,74 & 27,53 & \\
\hline & Laser & 5 & 18,99 & 3,56 & 14,38 & 24,10 & \\
\hline & PDT & 5 & 20,62 & 4,14 & 16,20 & 26,10 & \\
\hline & Total & 20 & 22,21 & 4,73 & 14,38 & 31,84 & \\
\hline \multirow{5}{*}{ Perímetro 24h } & Controle & 5 & 21,45 & 3,55 & 16,81 & 26,18 & \multirow{4}{*}{0,068} \\
\hline & Corante & 5 & 19,44 & 1,10 & 18,02 & 20,69 & \\
\hline & Laser & 5 & 16,94 & 1,39 & 15,18 & 19,04 & \\
\hline & PDT & 5 & 18,50 & 2,09 & 16,23 & 20,98 & \\
\hline & Total & 20 & 19,08 & 2,65 & 15,18 & 26,18 & \\
\hline \multirow{5}{*}{$\begin{array}{c}\text { Fator de Forma } \\
24 \mathrm{~h}\end{array}$} & Controle & 5 & 0,68 & 0,11 & 0,50 & 0,79 & \multirow{4}{*}{0,005} \\
\hline & Corante & 5 & 0,81 & 0,03 & 0,78 & 0,84 & \\
\hline & Laser & 5 & 0,82 & 0,03 & 0,78 & 0,86 & \\
\hline & PDT & 5 & 0,75 & 0,04 & 0,67 & 0,78 & \\
\hline & Total & 20 & 0,76 & 0,08 & 0,50 & 0,86 & \\
\hline \multirow{5}{*}{ Área $48 \mathrm{~h}$} & Controle & 5 & 24,27 & 5,09 & 17,11 & 30,93 & \multirow{4}{*}{0,996} \\
\hline & Corante & 5 & 25,20 & 6,96 & 16,14 & 34,42 & \\
\hline & Laser & 5 & 24,13 & 6,62 & 14,90 & 32,39 & \\
\hline & PDT & 5 & 24,89 & 4,80 & 18,74 & 30,63 & \\
\hline & Total & 20 & 24,62 & 5,47 & 14,90 & 34,42 & \\
\hline \multirow{5}{*}{ Perímetro 48h } & Controle & 5 & 21,51 & 2,74 & 17,20 & 24,63 & \multirow{5}{*}{0,555} \\
\hline & Corante & 5 & 19,98 & 3,16 & 15,65 & 24,24 & \\
\hline & Laser & 5 & 19,05 & 2,48 & 15,53 & 22,13 & \\
\hline & PDT & 5 & 20,08 & 2,20 & 16,80 & 21,93 & \\
\hline & Total & 20 & 20,16 & 2,61 & 15,53 & 24,63 & \\
\hline
\end{tabular}




\begin{tabular}{|c|c|c|c|c|c|c|c|}
\hline Variável & Grupo & $\mathrm{n}$ & Média & Desvio-padrão & Mínimo & Máximo & Significância (p) \\
\hline \multirow{5}{*}{$\begin{array}{c}\text { Fator de Forma } \\
48 \mathrm{~h}\end{array}$} & Controle & 5 & 0,66 & 0,11 & 0,47 & 0,74 & \multirow{4}{*}{0,018} \\
\hline & Corante & 5 & 0,78 & 0,04 & 0,73 & 0,82 & \\
\hline & Laser & 5 & 0,82 & 0,03 & 0,77 & 0,86 & \\
\hline & PDT & 5 & 0,77 & 0,06 & 0,68 & 0,83 & \\
\hline & Total & 20 & 0,76 & 0,09 & 0,47 & 0,86 & \\
\hline \multirow{5}{*}{ Área $72 \mathrm{~h}$} & Controle & 5 & 22,69 & 6,89 & 15,15 & 32,79 & \multirow{4}{*}{0,668} \\
\hline & Corante & 5 & 25,55 & 6,90 & 17,72 & 32,88 & \\
\hline & Laser & 5 & 21,43 & 4,12 & 15,78 & 26,31 & \\
\hline & PDT & 5 & 25,60 & 6,29 & 20,04 & 36,21 & \\
\hline & Total & 20 & 23,82 & 5,95 & 15,15 & 36,21 & \\
\hline \multirow{5}{*}{ Perímetro $72 \mathrm{~h}$} & Controle & 5 & 20,01 & 2,17 & 17,29 & 23,12 & \multirow{4}{*}{0,444} \\
\hline & Corante & 5 & 20,06 & 3,07 & 16,49 & 23,82 & \\
\hline & Laser & 5 & 18,17 & 1,56 & 16,30 & 20,05 & \\
\hline & PDT & 5 & 20,18 & 2,56 & 17,71 & 24,18 & \\
\hline & Total & 20 & 19,61 & 2,37 & 16,30 & 24,18 & \\
\hline \multirow{5}{*}{$\begin{array}{c}\text { Fator de Forma } \\
72 \mathrm{~h}\end{array}$} & Controle & 5 & 0,70 & 0,10 & 0,55 & 0,79 & \multirow{4}{*}{0,091} \\
\hline & Corante & 5 & 0,78 & 0,05 & 0,71 & 0,83 & \\
\hline & Laser & 5 & 0,80 & 0,04 & 0,74 & 0,83 & \\
\hline & PDT & 5 & 0,78 & 0,04 & 0,72 & 0,81 & \\
\hline & Total & 20 & 0,77 & 0,07 & 0,55 & 0,83 & \\
\hline \multirow{5}{*}{ Área 5 dias } & Controle & 5 & 20,27 & 7,05 & 10,48 & 29,17 & \multirow{4}{*}{0,625} \\
\hline & Corante & 5 & 13,65 & 4,74 & 7,47 & 18,76 & \\
\hline & Laser & 5 & 16,90 & 9,61 & 6,47 & 32,60 & \\
\hline & PDT & 5 & 18,67 & 8,17 & 12,12 & 29,25 & \\
\hline & Total & 20 & 17,37 & 7,42 & 6,47 & 32,60 & \\
\hline \multirow{5}{*}{ Perímetro 5 dias } & Controle & 5 & 18,54 & 3,28 & 13,25 & 22,03 & \multirow{4}{*}{0,488} \\
\hline & Corante & 5 & 14,73 & 2,58 & 10,87 & 17,44 & \\
\hline & Laser & 5 & 15,91 & 4,54 & 10,28 & 22,81 & \\
\hline & PDT & 5 & 17,20 & 3,75 & 13,66 & 22,69 & \\
\hline & Total & 20 & 16,60 & 3,62 & 10,28 & 22,81 & \multirow{5}{*}{0,649} \\
\hline \multirow{5}{*}{$\begin{array}{c}\text { Fator de Forma } 5 \\
\text { dias }\end{array}$} & Controle & 5 & 0,73 & 0,10 & 0,62 & 0,85 & \\
\hline & Corante & 5 & 0,77 & 0,07 & 0,65 & 0,82 & \\
\hline & Laser & 5 & 0,78 & 0,03 & 0,75 & 0,82 & \\
\hline & PDT & 5 & 0,76 & 0,08 & 0,65 & 0,86 & \\
\hline & Total & 20 & 0,76 & 0,07 & 0,62 & 0,86 & \\
\hline \multirow{5}{*}{ Área 7 dias } & Controle & 5 & 11,34 & 6,26 & 6,09 & 21,05 & \multirow{4}{*}{0,733} \\
\hline & Corante & 5 & 7,60 & 3,26 & 4,58 & 11,64 & \\
\hline & Laser & 5 & 10,31 & 6,74 & 4,45 & 17,92 & \\
\hline & PDT & 5 & 8,60 & 2,38 & 4,84 & 11,19 & \\
\hline & Total & 20 & 9,46 & 4,84 & 4,45 & 21,05 & \\
\hline \multirow{5}{*}{ Perímetro 7 dias } & Controle & 5 & 13,73 & 4,24 & 9,79 & 19,20 & \multirow{4}{*}{0,638} \\
\hline & Corante & 5 & 10,95 & 2,45 & 8,50 & 13,69 & \\
\hline & Laser & 5 & 12,39 & 4,28 & 8,61 & 17,31 & \\
\hline & PDT & 5 & 12,13 & 1,69 & 9,36 & 13,85 & \\
\hline & Total & 20 & 12,30 & 3,25 & 8,50 & 19,20 & \\
\hline
\end{tabular}




\begin{tabular}{|c|c|c|c|c|c|c|c|}
\hline Variável & Grupo & $\mathrm{n}$ & Média & Desvio-padrão & Mínimo & Máximo & Significância (p) \\
\hline \multirow{5}{*}{$\begin{array}{c}\text { Fator de Forma } \\
7 \text { dias }\end{array}$} & Controle & 5 & 0,73 & 0,09 & 0,59 & 0,81 & \multirow{4}{*}{0,173} \\
\hline & Corante & 5 & 0,77 & 0,04 & 0,72 & 0,82 & \\
\hline & Laser & 5 & 0,77 & 0,03 & 0,75 & 0,81 & \\
\hline & PDT & 5 & 0,72 & 0,02 & 0,69 & 0,73 & \\
\hline & Total & 20 & 0,74 & 0,05 & 0,59 & 0,82 & \\
\hline \multirow{5}{*}{ Área 10 dias } & Controle & 5 & 6,73 & 2,22 & 3,86 & 9,98 & \multirow{4}{*}{0,494} \\
\hline & Corante & 5 & 6,30 & 1,17 & 5,11 & 7,78 & \\
\hline & Laser & 5 & 5,28 & 1,90 & 3,55 & 8,17 & \\
\hline & PDT & 5 & 5,80 & 1,37 & 3,86 & 7,31 & \\
\hline & Total & 20 & 6,03 & 1,67 & 3,55 & 9,98 & \\
\hline \multirow{5}{*}{$\begin{array}{l}\text { Perímetro } 10 \\
\text { dias }\end{array}$} & Controle & 5 & 11,25 & 2,54 & 7,90 & 14,54 & \multirow{4}{*}{0,648} \\
\hline & Corante & 5 & 10,60 & 1,33 & 8,89 & 12,09 & \\
\hline & Laser & 5 & 9,72 & 2,27 & 7,45 & 12,76 & \\
\hline & PDT & 5 & 10,03 & 1,87 & 7,81 & 12,67 & \\
\hline & Total & 20 & 10,40 & 1,97 & 7,45 & 14,54 & \\
\hline \multirow{5}{*}{$\begin{array}{c}\text { Fator de Forma } \\
10 \text { dias }\end{array}$} & Controle & 5 & 0,69 & 0,18 & 0,36 & 0,79 & \multirow{4}{*}{0,894} \\
\hline & Corante & 5 & 0,71 & 0,10 & 0,54 & 0,81 & \\
\hline & Laser & 5 & 0,70 & 0,09 & 0,61 & 0,82 & \\
\hline & PDT & 5 & 0,73 & 0,10 & 0,57 & 0,84 & \\
\hline & Total & 20 & 0,71 & 0,12 & 0,36 & 0,84 & \\
\hline \multirow{5}{*}{ Área 14 dias } & Controle & 5 & 5,58 & 1,01 & 4,47 & 6,66 & \multirow{4}{*}{0,012} \\
\hline & Corante & 5 & 5,84 & 1,05 & 4,64 & 6,95 & \\
\hline & Laser & 5 & 3,51 & 0,69 & 2,49 & 4,32 & \\
\hline & PDT & 5 & 6,37 & 1,76 & 3,97 & 8,34 & \\
\hline & Total & 20 & 5,32 & 1,56 & 2,49 & 8,34 & \\
\hline \multirow{5}{*}{$\begin{array}{c}\text { Perímetro } 14 \\
\text { dias }\end{array}$} & Controle & 5 & 11,87 & 2,07 & 9,96 & 15,04 & \multirow{4}{*}{0,258} \\
\hline & Corante & 5 & 10,85 & 1,08 & 9,43 & 12,45 & \\
\hline & Laser & 5 & 9,33 & 2,24 & 6,40 & 12,66 & \\
\hline & PDT & 5 & 11,47 & 1,73 & 8,72 & 13,50 & \\
\hline & Total & 20 & 10,88 & 1,95 & 6,40 & 15,04 & \\
\hline \multirow{5}{*}{$\begin{array}{c}\text { Fator de Forma } \\
14 \text { dias }\end{array}$} & Controle & 5 & 0,51 & 0,14 & 0,37 & 0,72 & \multirow{5}{*}{0,622} \\
\hline & Corante & 5 & 0,62 & 0,13 & 0,49 & 0,80 & \\
\hline & Laser & 5 & 0,54 & 0,16 & 0,33 & 0,76 & \\
\hline & PDT & 5 & 0,60 & 0,11 & 0,48 & 0,73 & \\
\hline & Total & 20 & 0,57 & 0,13 & 0,33 & 0,80 & \\
\hline
\end{tabular}

